\title{
MITIGATION PLAN \\ FOR THE \\ MUDDY CREEK RESERVOIR PROJECT
}

\section{BIO/WEST, Inc.}

\begin{tabular}{c}
\hline \hline Resource Management \\
and Problem Solving Services \\
\hline
\end{tabular}

QH

541.5 


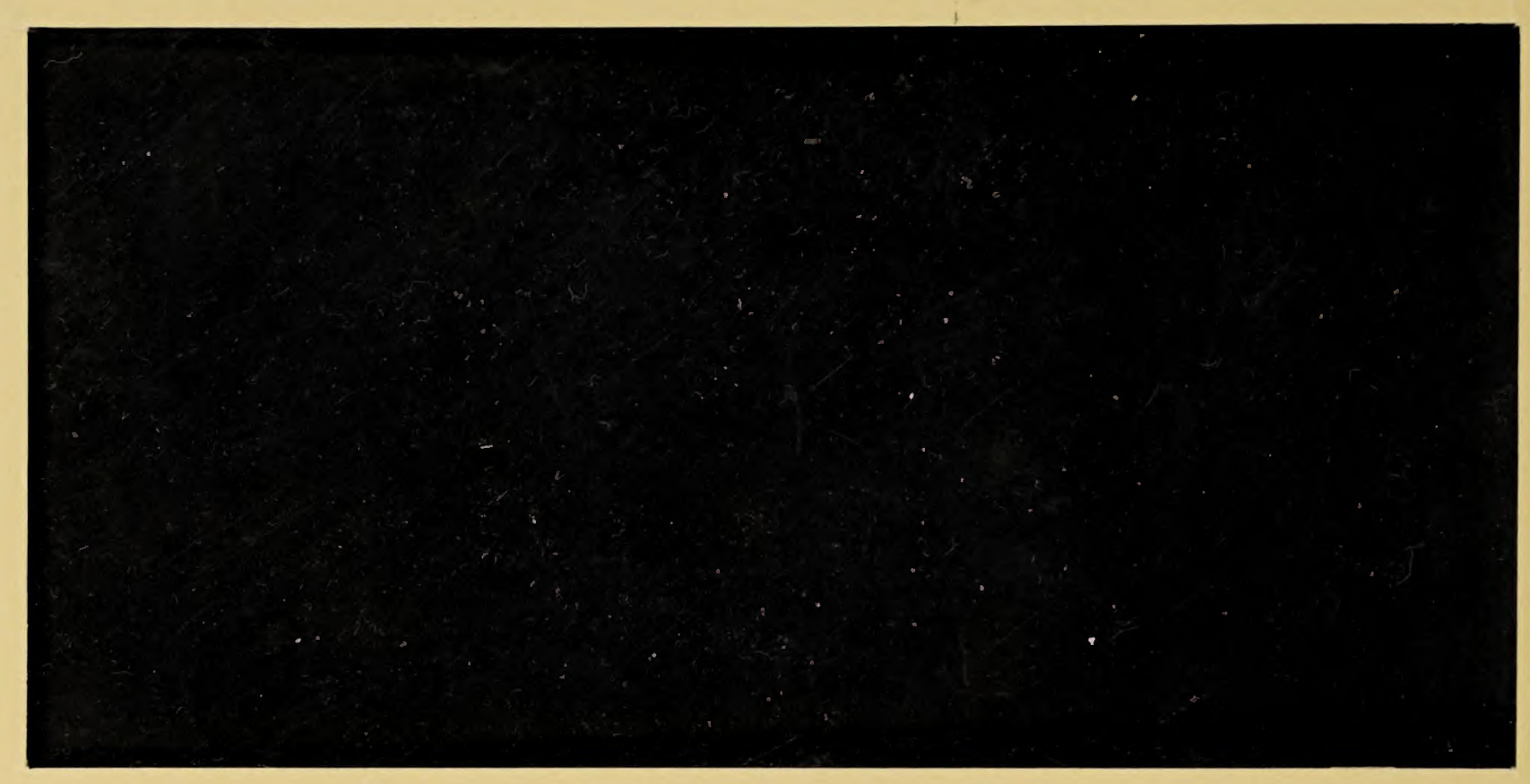


MITIGATION PLAN

FOR THE

MUDDY CREEK RESERVOIR PROJECT

\begin{abstract}
Prepared for
Bureau of Land Management-Colorado State Office United States Forest Servlce-Rocky Mountain Region

Co-Lead Agencies
\end{abstract}

\author{
Prepared by \\ BIO/WEST, Inc. \\ 1063 West 1400 North \\ BLM Library \\ Denver Federal Center \\ Bldg. 50, OC-521 \\ P.O. Box 25047 \\ Denver, CO 80225
}

Logan, Utah 84321 



\section{PREFACE}

In August 1988, the supplemental draft of the environmental impact statement (SDEIS) for the Rock Creek/Muddy Creek Resenoir, as proposed by the Colorado River Water Conservation District, was released for public comment jointly by the U.S. Forest Service and Bureau of Land Management. In the SDEIS it was noted that a detailed mitigation plan addressing certain impacts to wildlife, wetland habitat, and vegetation would be prepared. This document is that mitigation plan.

The first draft of this plan was sent to the state and federal agencies involved in September 1988. Comments and suggestions for improvements were received at a meeting held in Denver in October 1988. A subsequent draft was sent out for review in January 1989. Comments on that version were incorporated into the mitigation plan.

This mitigation plan was prepared by several members of the staff at BIONEST, Inc. in Logan, Utah. Specifically, Mr. Bill Masslich, mitigation specialist, oversaw much of the field work during the HEP analysis on the mitigation area, evaluated specific areas suitable for irrigation, and wrote most of the early drafts of the plan itself. Mr. Oliver Grah, soils/vegetation resources section manager, prepared the conservation plan for the federally listed endangered plant, Osterhout's milkvetch, and helped Mr. Masslich in determining approaches used to mitigate wetland habitat impacts. Dr. Roy Hugie, wildlife section manager, assisted Mr. Masslich in writing the final drafts of the plan, designing mitigation for minimizing impacts to wildlife and was responsible for overall coordination of the mitigation plan. Dr. Paul Holden, fisheries section manager and principal, prepared the fisheries enhancement section of the mitigation plan and aided in gathering public and agency input for the plan. The staff at Resource Consultant's, Inc. under the direction of Dr. Peter F. Lagasse, conducted the detailed engineering studies for the proposed irrigation system. 


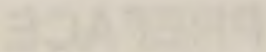

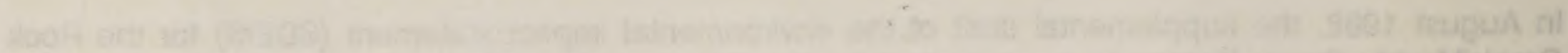

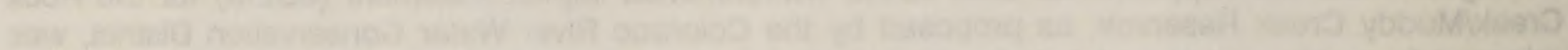
af

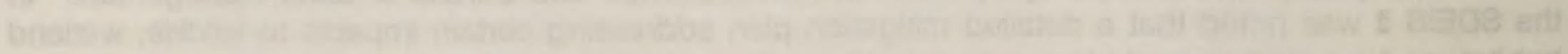

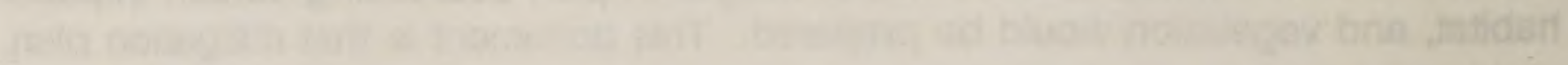

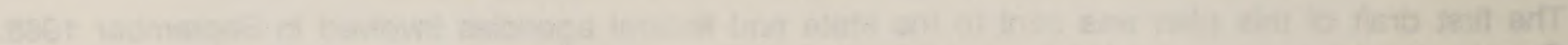

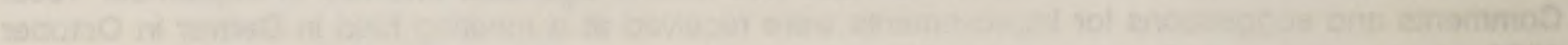

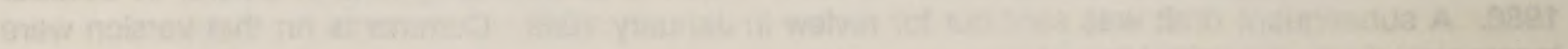

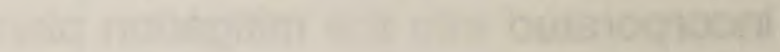

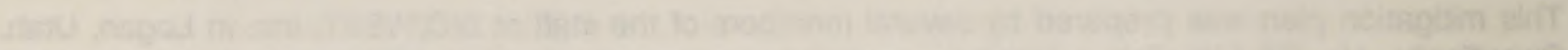

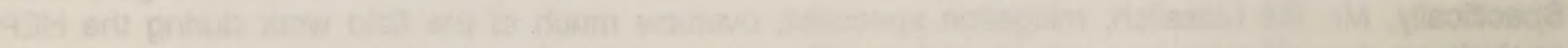

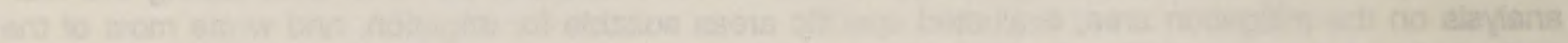

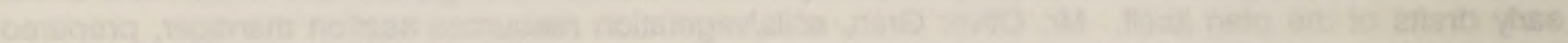

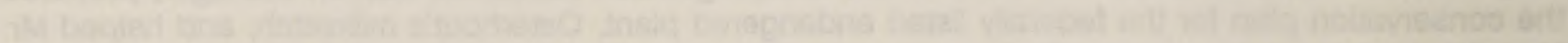
aㅏ. Cal molth

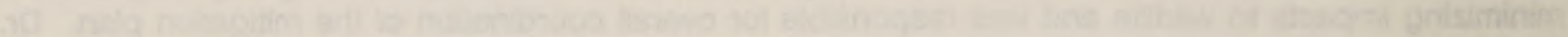

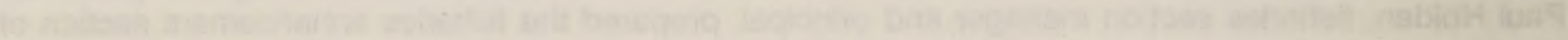

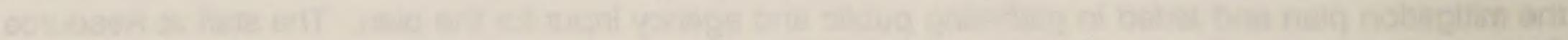

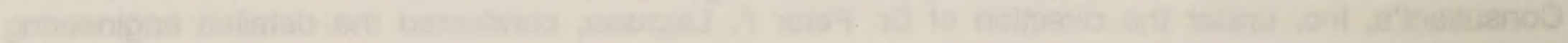




\section{EXECUTIVE SUMMARY}

Mitigation for impacts to wetland habitat, wildlife, and the endangered plant, Astragalus osterhoutii due to the proposed Muddy Creek reservoir were discussed in both the Draft EIS (USDA-FS 1987) and Supplemental Draft EIS (USDA/USDI 1988) for the proposed project. Following its selection as the Preferred Alternative, additional detailed mitigation planning was conducted resulting in this plan. Impacts and mitigation are discussed for three resources: wetland habitat, big game, and the endangered plant. Table I summarizes the impacts, mitigating measures proposed to offset those impacts, and the expected results of mitigation. The overall goal of mitigation was to replace all impacted values for each discipline as close to the area of impact as possible.

A team comprised of federal, state, and private biologists was formed in 1985 to guide the impact and mitigation process. Approximately 892 acres of wetland habitat would be impacted by the proposed reservoir project, but all the functional values of the impacted wetlands except wildlife habitat would be replaced by the reservoir. Therefore wildlife values were the only functional values that required mitigation. Impacts to wetland wildlife values were evaluated using HEP procedures, a method of quantifying values on different areas using wildlife indicator species. Models for three indicator species were selected by the team for use in evaluating Muddy Creek wetland habitat: beaver, yellow warbler, and a modified elk model. The EPA and Fish and Wildlife Service expressed concern over use of these models, primarily the elk model, near the end of the mitigation development process in 1988 . An additional model, the general wetlands habitat model, was developed and used to meet the concerns of these agencies.

The HEP procedures were used to evaluate the wildlife value of the 892 acres of impacted wetland habitat at the reservoir site using the four selected models (Table I). The same models were used to evaluate present conditions on the mitigation area selected by the team, the bottomland along Muddy Creek below the proposed dam. Management actions (Table I) that would be required to improve the wildlife values of the mitigation site were developed and include removal of livestock grazing, development of an irrigation system, planting wetland shrubs and trees and developing permanent pond habitat (Table I). Pond and cottonwood habitats were not adequately covered by the HEP analysis, therefore, their wildlife values were mitigated by acre-for-acre replacement. Mitigation would require about 410 acres of the lower Muddy Creek site plus an additional 40 to 50 acres at another site.

Big game impacts involved loss of 1,523 acres of winter range for deer and elk, potential increased future depredation on agricultural areas, and increased potential for big game-automobile collisions on Highway 40. Mitigation included fertilization and/or vegetation manipulation on 800 acres near Wolford Mountain and on 125 to 175 acres near the wetlands mitigation site; hay would be provided to attract big game away from agricultural areas, and signs would be placed along Highway 40 to reduce collision hazards (Table I).

Impacts to Osterhout's milkvetch included direct loss of 18 acres of habitat by inundation, disturbance of habitat by power line reconstruction, and indirect impacts due to recreational use of the plant's habitat along the proposed reservoir. Mitigation included a 5-year conservation study on the plant and its habitat, and securing two offsite populations by purchase exchange or conservation easement.

In addition to the three major areas of mitigation, additional enhancement and conservation measures are discussed. These include endangered fish conservation, stocking the reservoir with game fish, monitoring reservoir water quality, and enhancing fish habitat in the tailwater area.

Costs for the entire mitigation, enhancement and conservation package are projected at over $\$ 2$ million in 1989 dollars. 


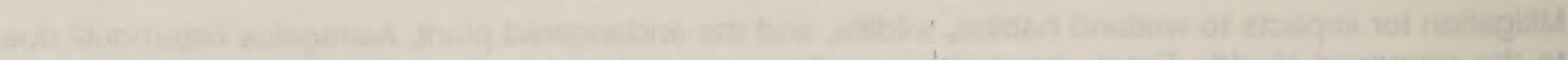

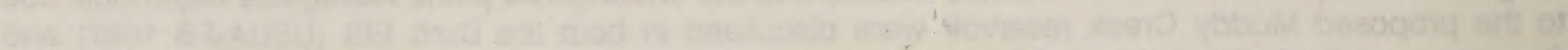

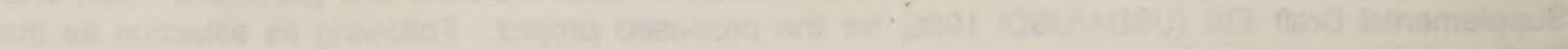

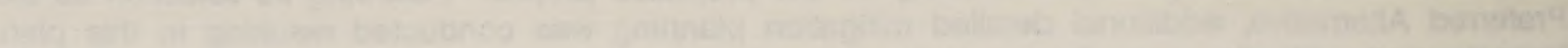

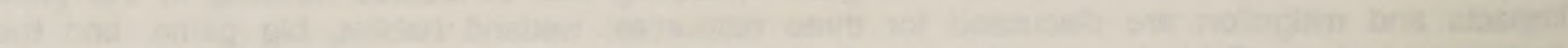

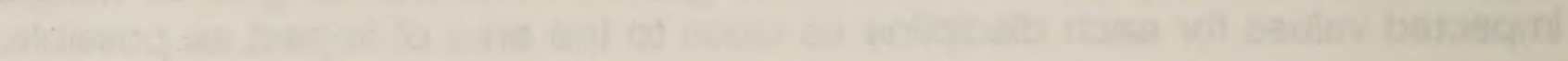

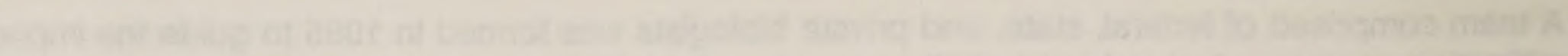

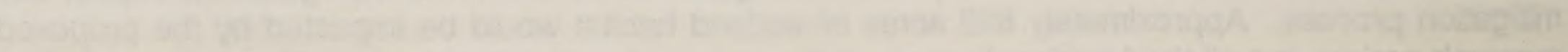

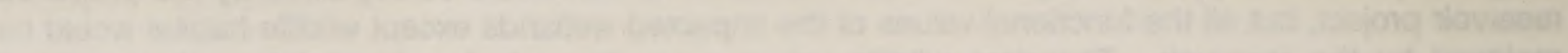

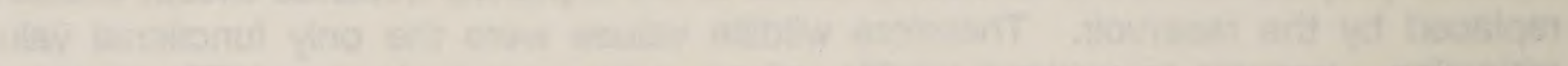
nothathatiat

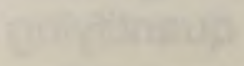

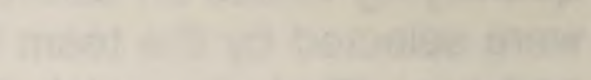

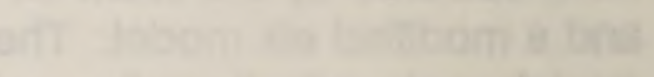

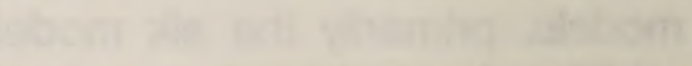

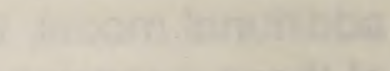

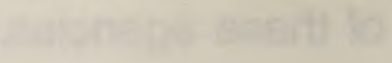

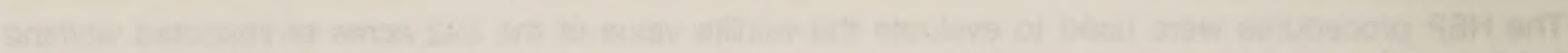

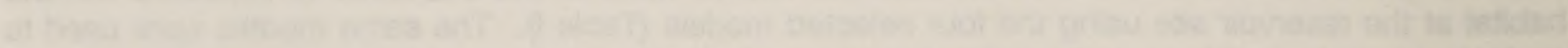

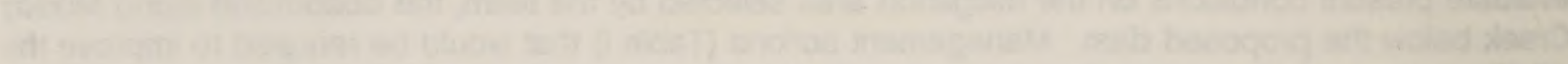

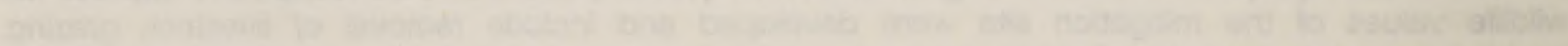
(15) (20)

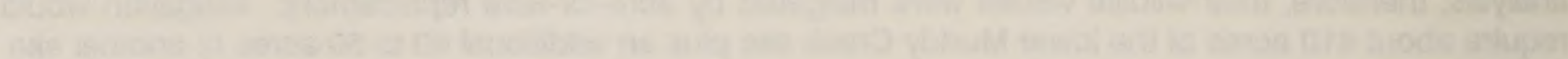

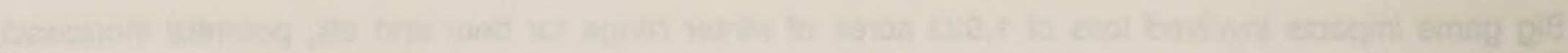

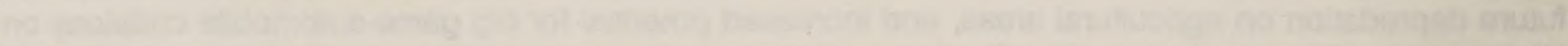

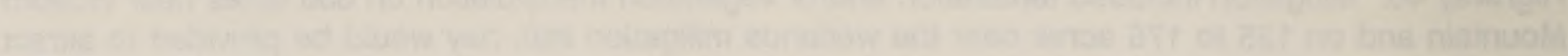
Whata (1)

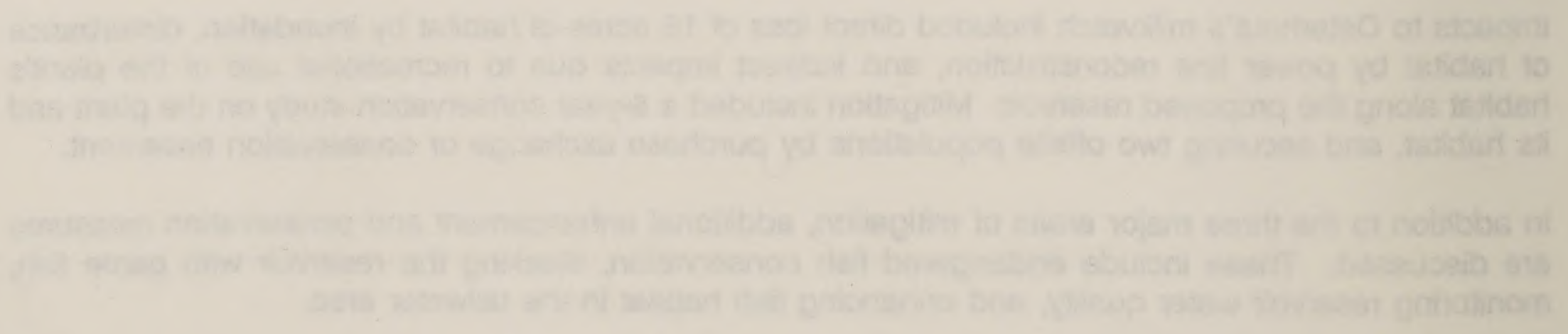


Table I. Summary of impacts, mitlgation measures and expected results for wetland habitat, blg game, and an endangered plant assoclated with the proposed Muddy Creek reservolr.

\section{Wetland Habitat}

892 acres impacted including 168 acres of artificially irrigated, meadow, 514 acres of natural wetlands in poor condition, and 210 acres of natural wetland in good condition.

Loss of 8 acres pond and 3 acres cottonwood habitat.

1,523 acres winter range lost.

Big game/motorist collisions increased.

Depredation of privately owned hay increased.

Loss of 18 acres of habitat and individuals due to inundation.

Indirect loss of plants and habitat due to recreational use along reservoir.

Potential loss of habitat by dam access road.
Enhance about 460 acres wetland in poor condition by removing grazing, developing an irrigation system, and planting 37 acres willow and 7 acres cottonwood. Establish a monitoring program.

Create 8 acres permanent pond habitat and plant 7 acres cottonwood.

\section{Big Game}

Fertilization/vegetation treatment on 800 acres near Wolford Mtn. and 175 acres along lower Muddy Creek.

Place warning signs along Highway 40.

Use hay to attract big game away from private land and fence privately owned hay.

\section{Osterhout's Milkvetch}

Conduct a 5-year conservation study of the plant and its habitat.

Protect two offsite populations through purchase exchange or conservation easement.

Survey route prior to construction.
Produce a net increase in wetland wildlife values by replacing more values in the mitigation area than would be lost in the reservoir area.

Replace cottonwood and pond habitat acre-for-acre.

Lost forage would be replaced.

Big game/motorist collisions reducod to present levels or lower.

Depredation of privately owned hay reduced to present levels or lower.

Strengthen the ability to protect plant in the future.

Provide assurance that plant would not be disturbed in these areas in the future.

Assure that additional direct impact would not occur. 


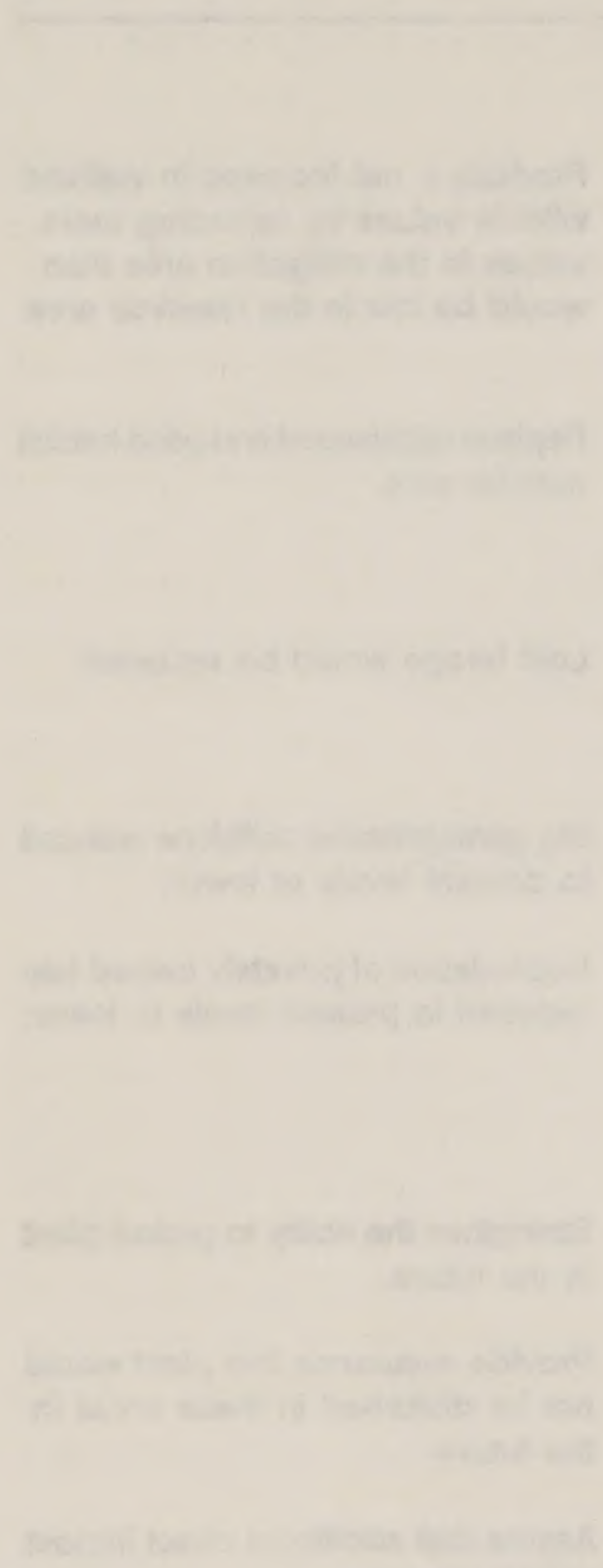

\section{(15)}

(a)

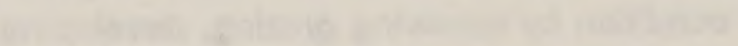

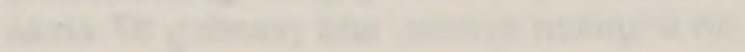

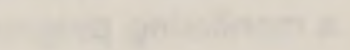

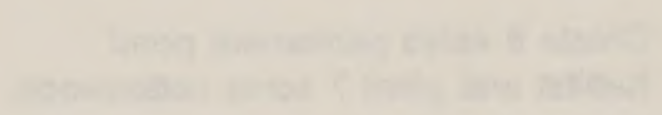

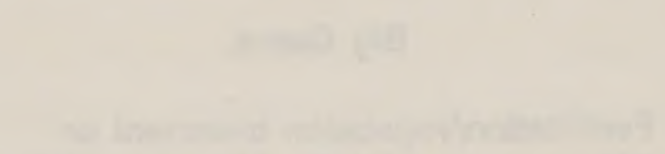

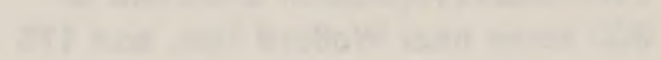

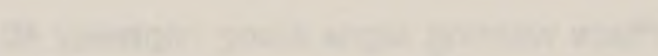
(1)

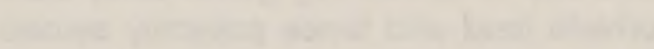

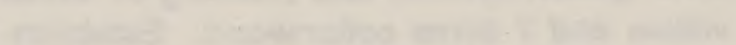

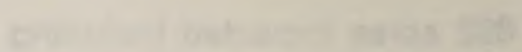

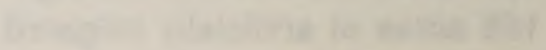

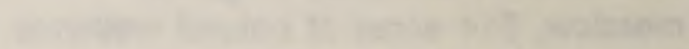

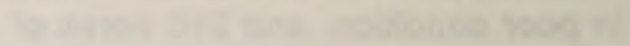

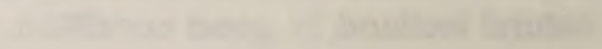

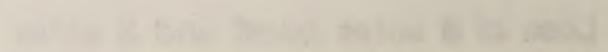

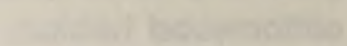

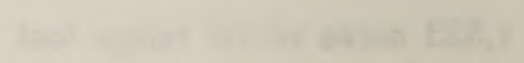

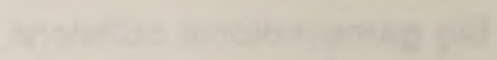

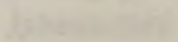

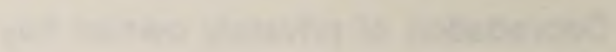

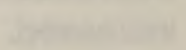

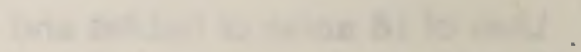

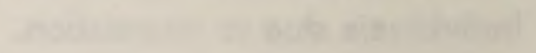




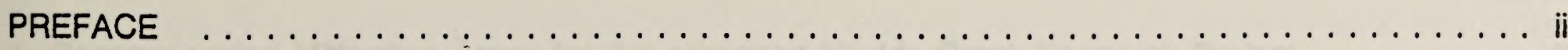

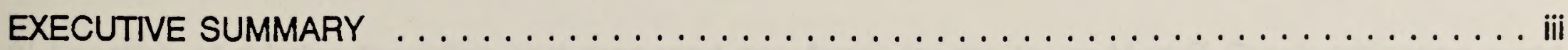

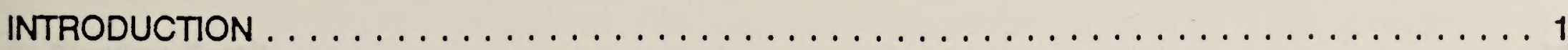

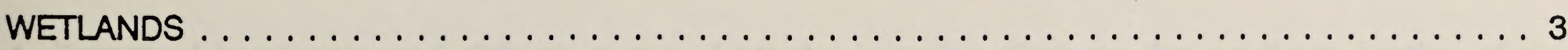

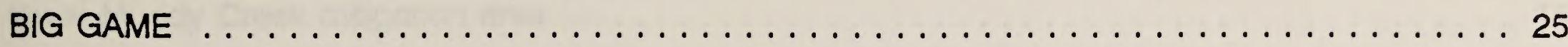

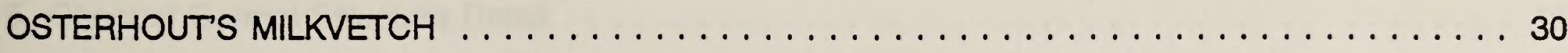

ADDITIONAL ENHANCEMENT AND CONSERVATION MEASURES $\ldots \ldots \ldots \ldots \ldots \ldots \ldots$

SUMMARY OF MITIGATION AND ENHANCEMENT COSTS $\ldots \ldots \ldots \ldots \ldots \ldots \ldots \ldots$

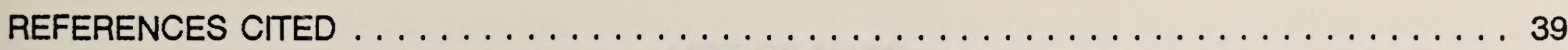

APPENDIX A: MUDDY CREEK FISHERIES ENHANCEMENT

APPENDIX B: CALCULATION OF THE HEP MODELS

Table

LIST OF TABLES

1 Summary of impacts to wetland wildlife habitat, big game and Osterhout's milkvetch

incurred as the result of construction and operation of the proposed Muddy Creek Reservoir. . . . 4

2 Summary of acreages of wetland types impacted by inundation and construction of

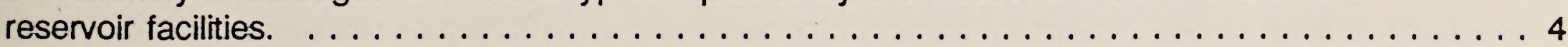

3 Summary of wetland types in the proposed project area based on their condition. . . . . . 5

4 Summary of impacts to wetland vegetation types and habitat units for HEP analysis. . . . . 8

5 Summary of wetland types and acreages present on the mitigation $\ldots \ldots \ldots \ldots \ldots$

6 Summary of acreages of wetland vegetation types influenced by the water management system on the proposed lower Muddy Creek mitigation area . . . . . . . . . . . . . . . . . 12

7 Impacts to big game winter range due to inundation and facilities construction . . . . . . 25

8 Time table of costs associated with mitigation management actions for the Muddy Creek

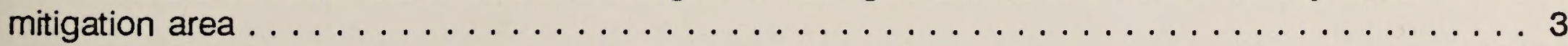

9 Summary of costs associated with the mitigation plan, fisheries enhancement program and rare fish

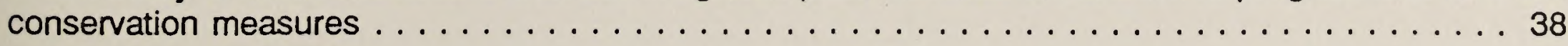





\section{LIST OF FIGURES}

\section{Flgure}

Page

1 Recommended Mitigation Areas for the proposed Muddy Creek Reservoir Project $\ldots \ldots \ldots$

2 Location of existing fenceline and proposed new fence for the lower Muddy Creek mitigation areat

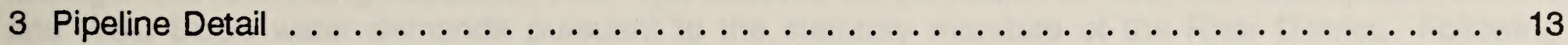

4 Proposed head gate and delivery system from the irrigation ditch on the southern section of the lower Muddy Creek mitigation area . . . . . . . . . . . . . . . . . . . . . 15

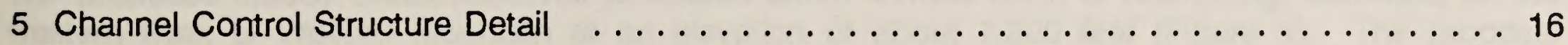

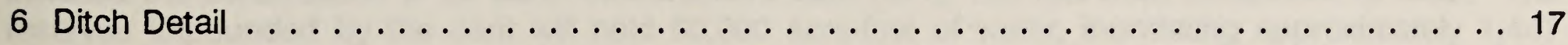

Map

LIST OF MAPS

(Inserted in map flaps)

1 Pipeline Layout

2 Irrigation Ditch

3 Willow and Cottonwood Planting and Sprig Cutting Sites - Northern Section

4 Willow and Cottonwood Planting and Sprig Cutting Sites - Southern Section

5 Proposed Transect and Photo Monitoring Sites 



\section{INTRODUCTION}

The Colorado River Water Conservation District (River District) submitted an application to the Forest Service on April 3, 1985, for a Special Use Permit for the construction of a water storage reservoir on Rock Creek in the Yampa Ranger District, Routt National Forest. In May 1988, the River District applied for a right-of-way to construct a dam and reservoir on Muddy Creek in the Bureau of Land Management Kremmling Resource Area. The reservoir will be utilized to meet both Metropolitan Denver and West Slope water demands pursuant to the statutory mandate of the River District. Following review of potential impacts associated with construction at both sites, the Muddy Creek Reservoir site was selected as the agency-preferred alternative.

The proposed Muddy Creek Reservoir is located about 4 miles north of Kremmling, Colorado, on the western flank of Wolford Mountain at an elevation of about 7,300 feet (Figure 1). The proposal includes the construction of an earth embankment dam rising 120 feet from streambed to crest. The reservoir impounded by the dam will hold 60,000 acre-feet of water, inundating approximately 1,447 acres. An additional 76 acres will be impacted by construction of proposed dam roads and other associated facilities. Details on the project area are presented in the SDEIS (USDI/USDA 1988).

Impacts associated with the proposed Muddy Creek Reservoir project for wetland habitat, wildlife, and Osterhout's milkvetch are presented in detail in the Rock Creek/Muddy Creek SDEIS (USDI/USDA 1988). The SDEIS (USDI/USDA 1988) also provides an outline of the conceptual approaches to mitigating impacts for these same resources. An interagency group including BLM, USFS, USFWS, COE, CDOW, EPA, and other interested parties participated in the selection of approaches to mitigating the identified impacts. This plan summarizes the impacts associated with the construction and operation of the proposed Muddy Creek Reservoir and presents a detailed plan for the mitigation of those impacts.

Because no impacts to fisheries in Muddy Creek are attributable to the construction or operation of the proposed Muddy Creek Reservoir, no mitigation for fisheries will be necessary. However, after construction of the reservoir there will be an opportunity to enhance fisheries both in the reservoir and in the tailwaters below the proposed dam. Because this is an enhancement rather than a mitigation measure, it will primarily be the responsibility of agencies or groups other than the River District. The River District is, however, supportive of this program. Implementation of the enhancement program would likely be concurrent with implementation of the mitigation plan. A discussion for fisheries enhancement measures is presented in Appendix $A$. 



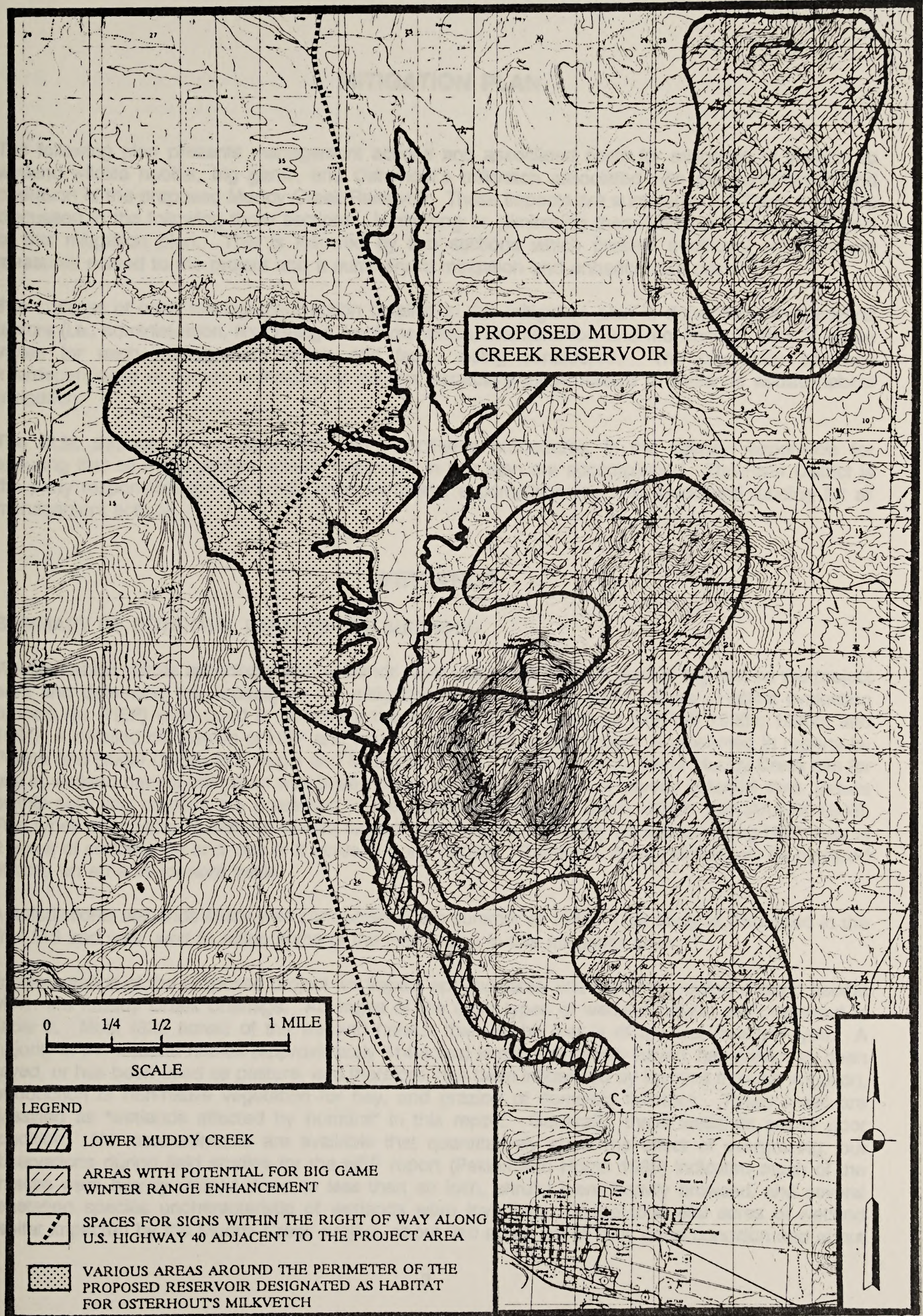

Figure 1. Recommended Mitigation Areas for the Proposed Muddy Creek Reservoir Project. 



\section{MITIGATION PLAN}

The following plan presents management actions and associated costs for mitigation of impacts to wetland wildlife habitat, big game, and Osterhout's milkvetch associated with the construction and operation of the proposed Muddy Creek Resenoir. These impacts are summarized in Table 1 and are discussed in the following three sections. Minimizing or eliminating these impacts is the overall goal of this mitigation plan. This is followed by two sections which present additional enhancement measures related to the project and a summary of mitigation and enhancement costs.

The success of each management action detailed in this mitigation plan is dependent upon several factors (i.e., administration, final design, implementation, maintenance, and monitoring). Risk of failure varies for each management action and factor being considered. The plan also assumes interdependency of certain management actions, especially those related to wetlands wildlife habitat mitigation.

The BLM, through permit stipulation and compliance procedures, is the agency responsible for ensuring that all management actions described in this plan are accomplished. The River District is the party responsible for the actual implementation, accomplishment, and associated funding for all management actions.

\section{WETLANDS}

\section{SUMMARY OF POTENTIAL IMPACTS AND METHODS}

Wildlife habitat values associated with wetlands were used as a basis to assess impacts on the project area and determine the capacity of the mitigation area to replace these values. Habitat evaluation procedures (HEP) were used to determine these wetland habitat values (USFWS 1980a; 1980b; and 1981). A detailed discussion of HEP and how it was applied to this project is presented in reports by Pekins and Hugie (1986) and Hugie and Masslich (1987). Selection of the lower Muddy Creek site for use in wetland habitat mitigation was based on an interagency review of several potential sites. Details of this selection process are presented in the Rock Creek/Muddy Creek SDEIS (USDA/USDI 1988). Two types of impacts to wetland wildlife habitat could not be effectively addressed using HEP: loss of 3 acres of cottonwood and loss of 8 acres of pond habitat. Therefore, these habitats will be replaced directly on an acre-for-acre basis.

A jurisdictional wetlands study was conducted in the summer of 1989 . That study is discussed in the final EIS and was used to refine some of the information in this mitigation plan.

Implementation of the proposed project will impact approximately 892 acres of existing wetland habitat within the Muddy Creek drainage. Acreages of the eight types of wetland habitat are presented in Table 2. Most ( 822 acres) of the wetland habitat that will be lost is of the wet meadow type. A majority of the wetland habitat (approximately 514 acres) is either presently hayed, has previously been hayed, or has been used as pasture, and therefore, has been influenced by humans through irrigation, introduction of non-native vegetation for hay, and grazing of domestic livestock. These areas are classified as 'wetlands affected by humans' in this report. Generally, these wetlands are in poor condition. No measurements are available that quantitatively show the effect of overgrazing, but observations during field studies for the HEP report (Pekins and Hugie 1986) indicated much of the grasses were heavily utilized down to less than an inch, shrubs were heavily browsed, and several vegetation species uncharacteristic of wetlands were invading. Of the total 892 acres of wetland habitat impacted by the Muddy Creek project, about 210 acres are in fairly good condition and about 

Table 1. Summary of Impacts to wetland wlldlife habitat, blg game, and Osterhout's mllkvetch.

Category and Impact Number

Description of Impact Before Mitigation

\section{Wetland Wildlfe Habltat}

1) Loss of 20 habitat units associated with wildlife species represented by the beaver model.

2) Loss of 14 habitat units associated with wildlife species represented by the yellow warbler model.

3) Loss of 193 habitat units associated with wetland wildlife species represented by the elk model.

4) Loss of wildlife habitat associated with 8 acres of pond habitat and 3 acres of cottonwood.

5) Loss of 186 habitat units associated with the general wetland habitat model on 825 acres of wet meadow.

\section{Big Game}

1) Loss of winter forage associated with 1,523 acres of big game winter habitat.

2) Mortality due to big game/vehicle collisions and drowning or other factors related to ice hazards on the reservoir.

3) Property damage associated with big game depredation on privately owned haystacks north of the proposed reservoir.

\section{Osterhout's Milkvetch}

1) Direct losses of individuals and habitat incurred during construction and operation of the proposed project.

2) Indirect impacts to the plant and its habitat incurred through recreational activities and private land development around the proposed reservoir.

Beneficlal Impacts

1) A net gain of approximately 1,400 acres of open water wildlife habitat that would primarily benefit waterfowl.

2) A net gain of approximately 108,000 linear feet of shoreline wildlife habitat that would primarily benefit waders, shorebirds and certain aquatic furbearers.

Table 2. Summary of acreages of wetland types Impacted by inundation and construction of reservoir facilities.

$\begin{array}{llll}\text { Community Type } & \text { Inundation } & \text { Facilities } & \text { Total Acres }\end{array}$

Wet meadow

Willow riparian

Cottonwood/willow riparian

Fast moving stream

Slow moving stream

Standing water with floating rooted plants

Standing water with cattails

$\begin{array}{rrr}822 & 3 & 825 \\ 38 & 0 & 38 \\ 3 & 0 & 3 \\ 16 & 0.5 & 16.5 \\ 1 & 0 & 1 \\ 7 & 0 & 7 \\ 1 & 0 & 1\end{array}$



Table 3. Summary of wetland types in the project area based on their condition.

\begin{tabular}{lr} 
Wetland Type and Condition & Acres \\
\hline Wetlands in Poor Condition & 682 \\
Wet meadow & \\
Wetlands in Good Condition & 143 \\
Wet meadow & 38 \\
Willow riparian & 8 \\
Ponds & 3 \\
Cottonwood/willow riparian & 18 \\
Streams &
\end{tabular}

682 acres have been affected by humans (Table 3). Of the 210 acres of high-value wetlands, approximately 143 are wet meadow; 38 acres are willow riparian; 17 acres are fast moving stream; 1 acre is slow moving stream; 8 acres are standing water; and 3 acres are cottonwoods.

The functional values of wetland habitat includes groundwater discharge and recharge, flood storage and desynchronization, shoreline anchoring and dissipation of erosive forces, sediment trapping, nutrient retention and removal, food chain support, wildlife and fish habitat, and active and passive recreation and heritage value (Adamus and Stockwell 1983).

Because the wetlands that will be inundated in the project area are in generally poor condition (USDAVUSDI 1988), the overall functional value of these wetlands is low. Land management activities have resulted in compacted soils, overgrazing, vegetation cropping, and subsequent lowering of the natural water table due to widening and incisement of Muddy Creek below its floodplain. Recent analysis completed by BIONEST and RCl (Grah 1989) provides evidence that Muddy Creek has abandoned the valley flat area as an active floodplain due to channel widening and incisement. In general, point bars and an incipient floodplain are being newly constructed by the creek at a level two to three feet below the abandoned floodplain level.

In addition, based on information presented by Adamus and Stockwell (1983), the reservoir will replace or improve most of the low functional values of the inundated wetlands except wildlife value. These functional values include the following:

Groundwater Discharge: This functional value involves the role wetlands play in regulating stream flows through groundwater discharge. At present, it appears that the Muddy Creek wetlands are not retaining as much of the surface water runoff as would a wetland in better condition. Hence, a reduced quantity of surface water infiltrates or percolates into the groundwater. Therefore, groundwater discharge from the Muddy Creek wetlands to the creek is reduced from levels associated with a wetland in good condition. The reservoir will fully replace or exceed the value of this low flow augmentation. First, the reservoir will increase the hydraulic head of groundwater above and below the reservoir. Such an increase in hydraulic head could effectively raise the water table below the dam thereby increasing baseflow augmentation as well as consumptive use by the hydrophytes. Second, reservoir management will involve releasing greater flows than that of the current situation during lowflow periods. Therefore, the presence and operation of the reservoir will replace or exceed the current groundwater discharge value of the inundated wetlands. 

Groundwater Recharge: Although Muddy Creek provides some groundwater recharge, there is a net loss of groundwater in the Muddy Creek basin due to consumptive use by hydrophytes and widening and incisement of the stream channel, which has caused a reduction in hydraulic head in wetlands adjacent to the stream. The reservoir will greatly increase the hydraulic head and provide a large source of water that will effectively cause groundwater mounding in the reservoir's vicinity. The groundwater mounding essentially represents an increase in groundwater recharge. Therefore, the reservoir will not only replace the recharge functional value, but will greatly enhance the existing rate of groundwater recharge.

Flood Storage and Desynchronization: The wetlands that will be impacted occur on the Muddy Creek valley flat. On the average, streams overtop their banks and inundate their floodplain one or more times in 1.5 years. When a stream overtops its banks, the vegetation on the floodplain slows the velocity of water flow and detains a portion of the flood flow. These processes effectively slow flood flow and desynchronize the flow to minimize damage to downstream areas due to an otherwise "flashy" flow regime. The effectiveness of the wetland depends on the density of cover and the horizontal and vertical structure of the cover. As indicated, the wetlands associated with Muddy Creek have been overgrazed to the point where flood storage and desynchronization values are relatively low. Further, Muddy Creek does not overtop its banks as often as a stream in a more pristine condition due to widening and incisement which additionally reduces functional value of the wetlands. Reservoirs have been extensively used for flood control and their value in flood storage and desynchronization is high. Therefore, the Muddy Creek Reservoir will more than fully replace this functional value of the wetlands lost with construction of the Muddy Creek project.

Shoreline Anchoring and Dissipation of Erosive Forces: The widening and incisement of Muddy Creek has left a substantial portion of its banks bare. Most of the vegetation that lined the creek has either been left above the stream, out of effective influence in terms of bank protection, or has sloughed into the creek due to bank erosion. Therefore, the existing wetlands are not of high value in regard to shoreline anchoring and dissipation of erosive forces. The reservoir will inundate and replace a deeply incised segment of Muddy Creek. Because reservoirs have low erosive energy, the Muddy Creek Reservoir will more than substitute for the reduced value of the inundated wetlands.

Sediment Trapping: The ability of a wetland to trap sediment is directly related to its ability to store and desynchronize flood waters. Therefore, the discussion presented above for flood storage and desynchronization applies to sediment trapping. Since the Muddy Creek wetlands are generally in very poor condition, their sediment trapping effectiveness is low. This especially applies to trapping of sediments due to overland flow and flooding of the valley flat area. Wetlands with low vegetative cover and density, such as in the Muddy Creek basin, make poor sediment filters. Reservoirs are well known for their ability to trap sediments. Reservoir design life is based on the calculated time frame within which a reservoir is likely to be rendered ineffective due to sediment deposition and reduced water storage capacity. Consequently, the reservoir's ability to trap sediment will greatly exceed the existing wetland's ability by several orders of magnitude.

Nutrient Retention and Removal: A large portion of nutrient inflow into a wetland occurs as chemical species attached to sediment particles which are trapped by the wetland vegetation as described above. Currently, the degraded condition of the Muddy Creek wetlands have greatly reduce this functional value. These sediment particles would sink in and be retained by the reservoir. Dissolved nutrients are retained by wetlands through uptake by vegetation. Since the Muddy Creek wetlands vegetation is in poor condition, the actual magnitude of dissolved nutrient uptake is greatly reduced as compared to a wetland in good condition. The greater density of dissolved nutrients will cause the solution to sink to the bottom of the reservoir into the conservation pool. Thus, a large portion of the nutrient inflow is trapped in the conservation pool. Reservoirs act as thermal regulators and nutrient 


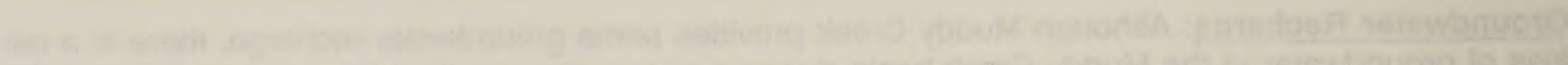
(3.7. The The Chate Chat

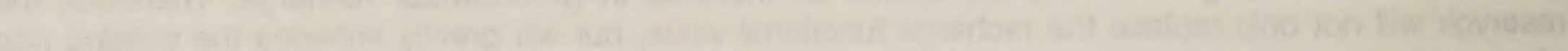

-

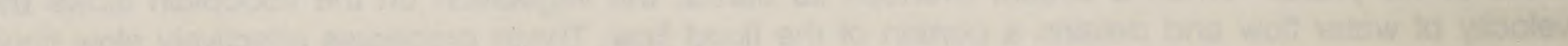

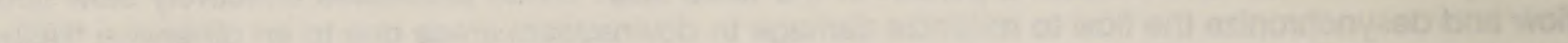
(5) 
sinks so that short-term fluctuations in water quality which are characteristic of natural riverine systems are regulated (Petts 1984). Reservoirs can be very efficient nutrient traps. For example, Schrieber and Ross (1979) reported a 50 percent reduction in mean inflow concentrations of orthophosphate and a four-fold reduction in the total suspended sediment phosphorus between the inflow and outflow on Callahan Reservoir, Missouri. High value wetlands also function as efficient nutrient traps. However, due to the poor quality of the Muddy Creek wetlands, nutrient retention is minimal and a reservoir would function as a more efficient nutrient sink. These processes indicate that the Muddy Creek Reservoir's capacity for nutrient retention will greatly exceed the capacity of the existing wetlands.

Food Chain Support: It is very difficult to compare these functional values for a wetland in poor condition with a reservoir since both support very different food links, chains, and webs. It is very likely that the reservoir will offer greater but different value than the wetlands in poor condition.

Wildlife and Fish Habitat: The aquatic biology section of the SDEIS (USDI/USDA 1988) establishes that the existing fishery of Muddy Creek is poor to non-existent. Similarly, HEP studies indicated a poor value in terms of wildlife habitat provided by these wetlands. However, the poor value of habitat over the area to be inundated adds up to a substantial quantity of habitat units that will be lost with wetland inundation. The reservoir will not replace or substitute for these units. Therefore, a reduction and loss of this value will occur with reservoir construction and operation. However, the reservoir will provide a large area of open water habitat type.

Heritage and Recreation Values: Wetlands are relatively rare and unique in the region. The contrast in line, form, color, and texture with the surrounding upland vegetation provides a visually pleasing and interesting landscape which most people value. In addition, many people enjoy and appreciate wetlands as unique biological and physical systems. Further, a major value of wetlands lies in the passive and active recreation opportunities they offer such as boating and waterfowl hunting. Unfortunately, the poor condition of the Muddy Creek wetlands greatly reduces their heritage value potential. Reservoirs also provide visually pleasing and interesting landscapes due to similar contrasts. The reservoir will provide substantially greater recreation opportunities in terms of fishing, sight seeing, boating, etc. Therefore, the heritage and recreation value provided by the Muddy Creek Reservoir will greatly exceed the value provided by the existing wetlands.

In summary, the only functional value losses due to wetland inundation relates to wildlife habitat. The resenoir will either replace in equivalence or in excess the other functional values associated with the existing Muddy Creek wetlands.

As noted above, providing habitat for various species of wildlife is one of the important values of wetlands. Quantifying losses of wildlife habitat values within the project area wetlands was accomplished using HEP. A summary of impacts to wetland wildlife habitat based on habitat units calculated from the HEP analysis is presented in Table 4.

Evaluation species used to assess wetland habitat values associated with the proposed project included the beaver, yellow warbler, and elk. At the time the HEP project was conducted (1986 and 1987), the HEP team (BIONEST, CDOW, BLM, USFWS, USFS, BLM, EPA, COE and others) found that these species models suited the Muddy Creek project and mitigation areas. The beaver and yellow warbler models were readily suited for modeling the willow/riparian types of wetland habitats present on the proposed project and mitigation area. Consequently, the habitat values derived from the use of these models allowed an accurate assessment of potential impacts and management actions needed to mitigate these impacts. The elk model was designed to model montane habitats that include wetlands as a feature of the habitat. Adjustment and recalculation of the elk model was 



\begin{tabular}{|c|c|c|c|c|c|}
\hline \multirow[b]{2}{*}{ Vegetation Type } & \multirow[b]{2}{*}{ Acreage } & \multirow[b]{2}{*}{ Beaver } & \multicolumn{2}{|c|}{.....Habitat Units } & \multirow[b]{2}{*}{ GWH } \\
\hline & & & Yellow Warbler & Elk & \\
\hline Wet meadow & 825 & 0 & 0 & 159 & 186 \\
\hline Willow/cottonwood riparian* & 41 & 20 & 14 & 34 & 0 \\
\hline Total & 866 & 20 & 14 & 193 & 186 \\
\hline
\end{tabular}

necessary in order to apply it to the wet meadow habitats on the project area. Details on calculation of habitat units for the three species models used, including modifications, are presented in Appendix B.

Following review of the draft mitigation plan, concern was expressed that the models used to evaluate wildlife habitat values on the project and mitigation areas did not adequately quantify habitat values associated with the wet meadow vegetation type. Therefore, a generalized model was developed by BIOMEST for the purpose of determining wildlife habitat value associated with these areas. Parameters used in the model were restricted to those for which data were collected during previous HEP studies on the project and mitigation areas. This model was formulated to show optimum values when conditions were similar to pristine or lightly grazed wet meadow habitat in surrounding or similar areas. For purposes of discussion this model is called the "general wetland habitat model" (GWH) and is not related to any particular wildlife species. Prolonged overgrazing in the Muddy Creek area has effectively impacted riparian vegetation and floodplain hydrology to the point that much of the wildlife habitat on the area is in very poor condition or nonexistent. Extensive research on the deleterious effects of overgrazing on riparian areas and associated wildlife habitat indicates that ungrazed riparian areas provide habitat for a far greater number and diversity of wildlife species than grazed areas (Cooperrider et al. 1986). Consequently, the curves developed for the GWH model are intended to maximize suitability indices for herbaceous parameters at levels that were observed or known to occur in an ungrazed wet meadow. The wet meadow habitat was categorized as being in good or poor condition for purposes of analysis. Parameter values for each category were based on estimates of heavily grazed, moderately grazed, and lightly grazed conditions using HEP data as a baseline. The model was applied to all 825 acres of wet meadow habitat including naturally subirrigated and artificially irrigated. A summary of the results using the GWH model is shown in Table 4 and details on calculation of habitat units for the GWH model used, including suitability curves are presented in Appendix B.

\section{WETLAND HABITAT MITIGATION AREAS}

\section{Lower Mitigation Area}

The proposed lower Muddy Creek mitigation area is comprised of approximately 865 acres, of which approximately 20 acres are stream and approximately 390 acres of bottomland surrounding Muddy Creek are of prime interest in mitigating wetland-associated impacts. Of the 390 acres, approximately 


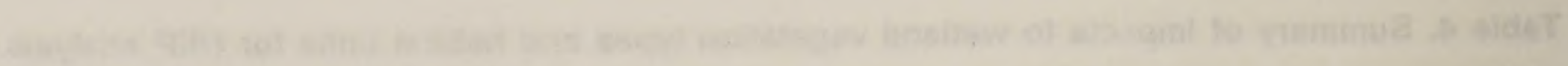

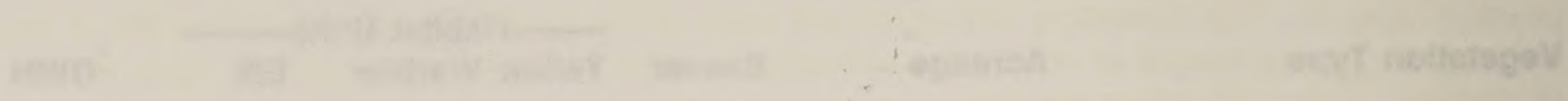

371 -

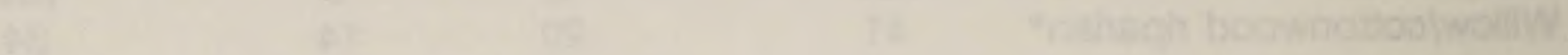

(11)

inetals

-

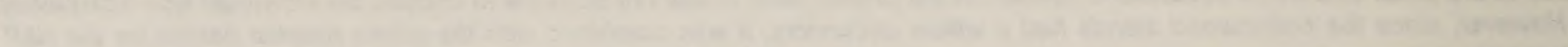

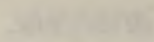

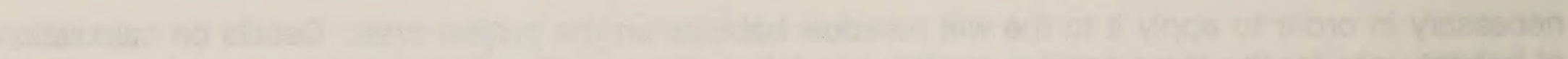
Than

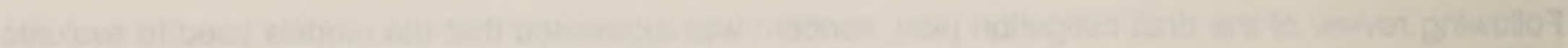

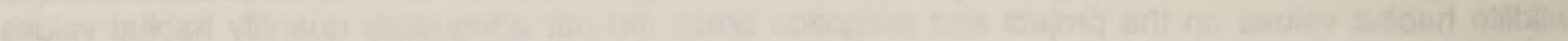
aㅏ.

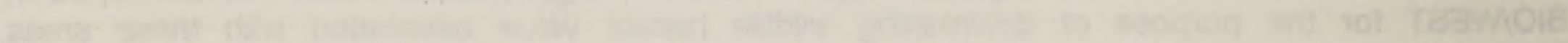

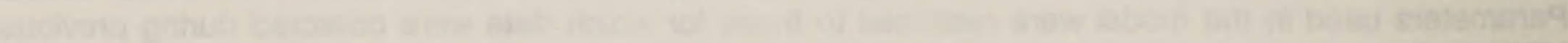
-

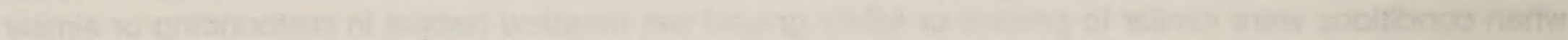

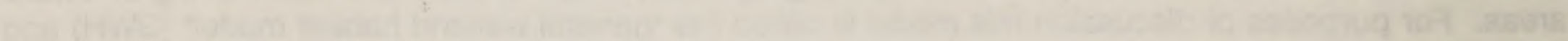

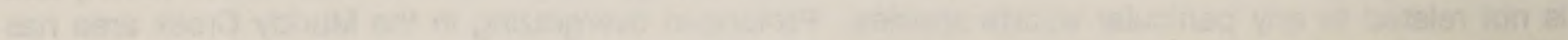
Than

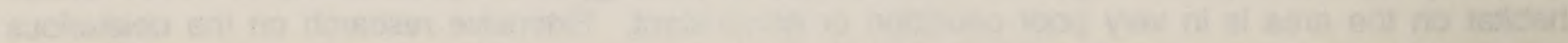
Than

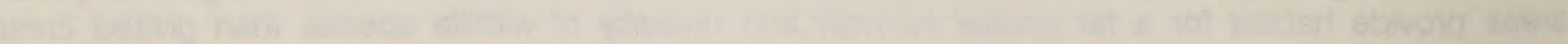

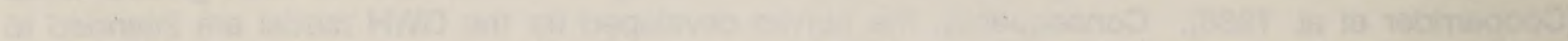

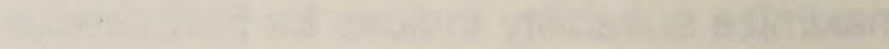

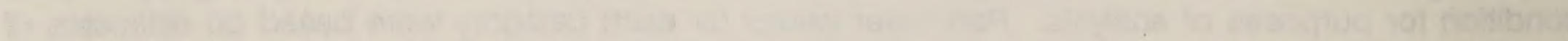
That

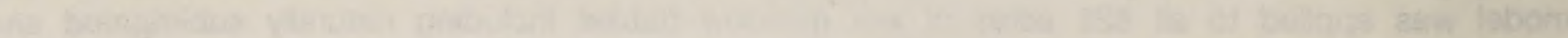
(4.

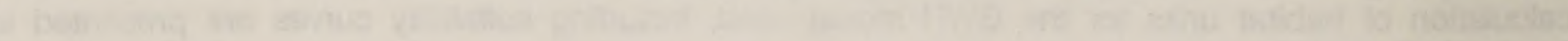
$x+50525$

divania

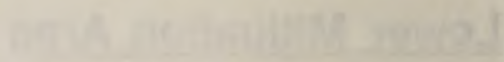

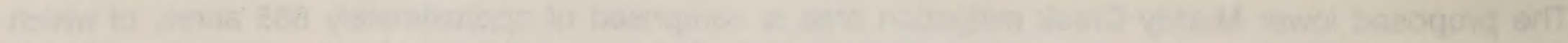

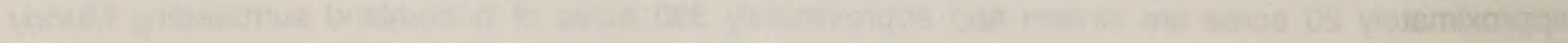

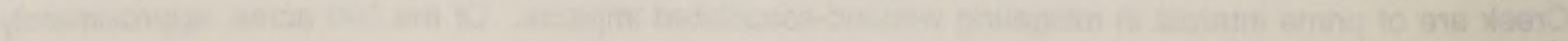


80 acres are owned by the State of Colorado, approximately 149 acres are managed by the BLM, and approximately 161 acres are privately owned. This includes 210 acres of wet meadow, 135 acres of willow riparian, 19 acres of cottonwood/willow riparian and 26 acres of temporarily flooded oxbow ponds (Table 5). The remaining 455 acres are parts of the three privately owned blocks of land that will have to be purchased or otherwise controlled in order to obtain management rights on the acres of interest. These $\mathbf{4 5 5}$ acres are mainly comprised of sagebrush uplands adjacent to the Muddy Creek bottomlands. Existing wetlands on the proposed mitigation site are generally in poor condition due to overgrazing of wetland vegetation and stream channel degradation which has lowered the level of the water table throughout a large portion of the bottomlands surrounding Muddy Creek. Most of the sagebrush uplands surrounding Muddy Creek will also be used as big game winter range mitigation sites.

Table 5. Summary of wetland types and acreages present on the mitigation area.

Wetland type Acres Percent of Area

Wet meadow

Willow riparian

Cottonwood/willow riparian

Temporarily flood oxbow ponds

Stream

$\begin{array}{rr}210 & 51 \\ 135 & 33 \\ 19 & 5 \\ 26 & 6 \\ 20 & 5\end{array}$

Total

\section{Wetlands Adjacent to the Reservoir Perimeter}

The lower Muddy Creek mitigation site will fully mitigate all wetland wildlife habitat impacts with the exception of 23 habitat units associated with the wet meadow habitat type based on the GWH model. Assuming that the lands used to mitigate these 23 habitat units will be in similar or worse condition to wet meadow in the reservoir basin (i.e., $\mathrm{HSI}=0.470$ ), approximately 43 additional acres will be needed. This additional land will be acquired from one or a combination of the following areas in order of preference: 1) wetlands occupying tributary drainages on the perimeter of the proposed reservoir; 2) wetlands within the lower Muddy Creek drainage south of the present mitigation area; and 3) offsite wetlands. This land will be acquired during the purchase of the land necessary for the operation of the reservoir prior to construction.

\section{WETLAND HABITAT MANAGEMENT ACTIONS}

Six management actions are needed to mitigate impacts to wetland habitat within the project area. These wetland habitat management actions, including details on implementation and costs, are presented in the next section. This is followed by a section that presents each impact, identifies which management actions apply to that impact, and presents the results that are expected by implementation of the management actions. 


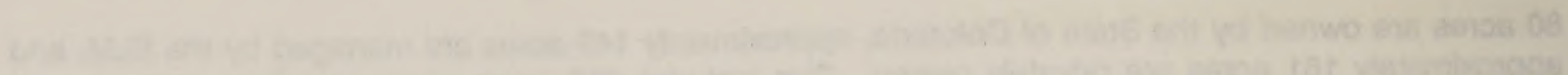

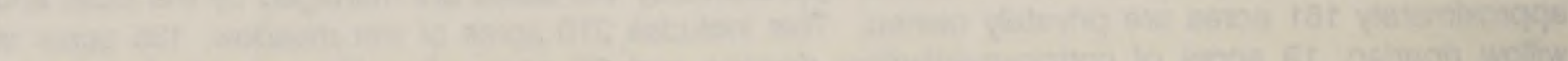
C.9.

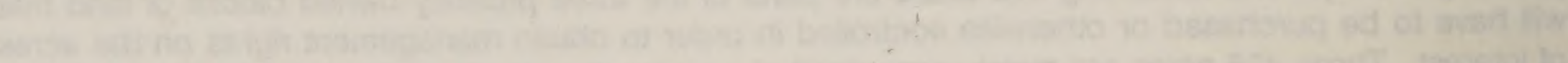

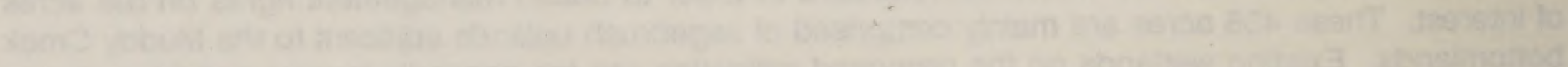

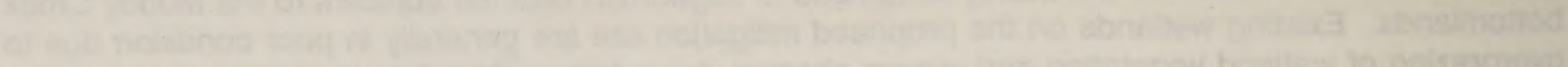

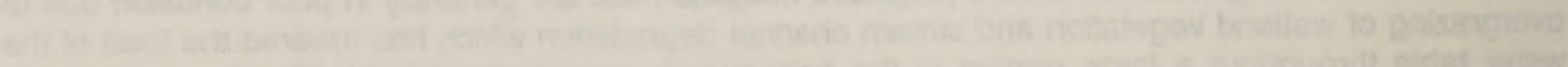

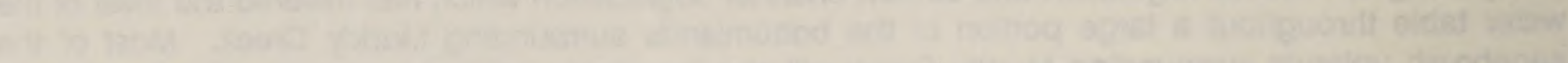

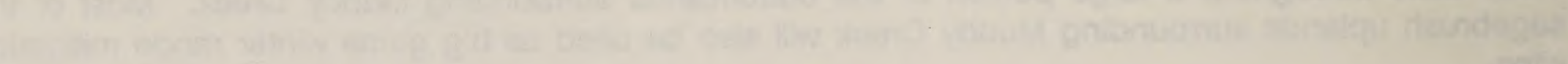

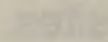

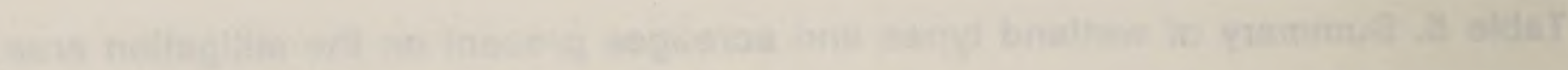
-

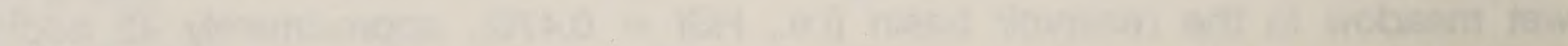
The

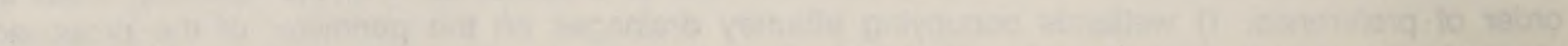

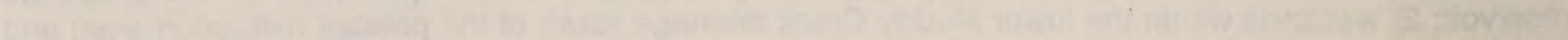

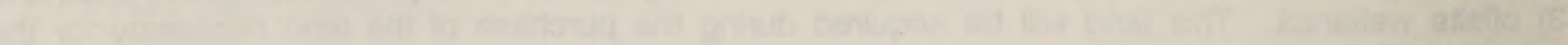

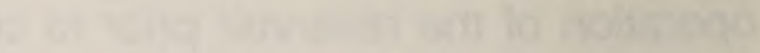




\section{Wetland Habitat Management Action \#1}

Eliminate grazing from the riparian areas within the 410 acres of the lower Muddy Creek mitigation area by fencing and redistributing grazing on public and private lands surrounding the mitigation area.

\section{Responsible Agency: BLM \\ Cooperating Parties/Agencies: CDOW, Colorado State Lands Board}

Fencing: Figure 2 illustrates existing fence on the mitigation area and presents a layout of additional fencing needed to restrict livestock from the riparian corridor. Approximately 5.5 miles of existing fence on the mitigation area is suitably located for purposes of restricting livestock. Various sections of this fence are in poor condition and must be repaired or replaced. It will be necessary to inspect all existing fence and repair where needed. Approximately 3.0 miles of additional fencing is needed to connect existing fence to securely restrict livestock access into the riparian area. This fence will be constructed according to BLM specifications in order to minimize mortality of big game.
Estimated cost: $\quad$ - Construction of 3 miles of new fence @ $\$ 4,500 /$ mile $=\$ 13,500$
- Repair of existing fence $=\$ 12,000$
Total estimated cost $\quad-\$ 25,500: 0 \& M$ costs for fencing $=\$ 600 / y r$

Grazing Redistribution: Portions of BLM allotment \#7550 within the bottomland of Muddy Creek will be fenced off from livestock. Redistribution of grazing on the allotment will be accomplished by placing a stock water tank at the southwest corner of the allotment (Figure 2). Water will be supplied to the tank via a tap into the domestic water system of Kremmling in the proximity of the proposed tank. Arrangements with the City of Kremmling and the acquisition of an easement to pipe the water a short distance over private land will be made prior to developing the watering facility. Water will be made available for livestock on the east side of the allotment through a watering gap to Muddy Creek or another reliable source of water that is included in plans for the construction of new fence.

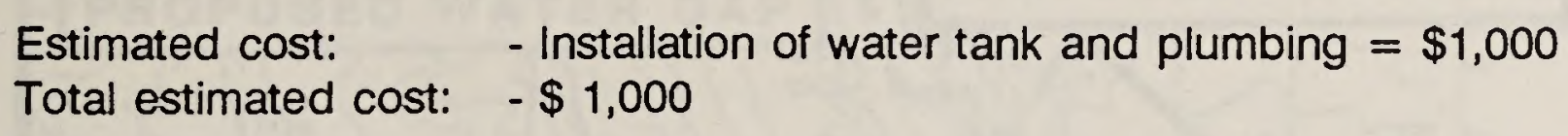

Total estimated cost: $\quad-\$ 26,500$

\section{Wetland Habitat Management Action \#2}

Establish a water management system that will effectively create a perennially wet situation allowing for the restoration, enhancement, and maintenance of up to 249 acres of wetland vegetation types on the lower Muddy Creek mitigation area.

Development of plans for a water management system in the lower Muddy Creek mitigation area will involve construction and use of new facilities in the northern portion of the mitigation area and the repair and upgrade of existing irrigation facilities in the southern section of the mitigation area. For purposes of presentation of management action \#2, the proposed mitigation area will be divided into two sections which will be referred to as the northern section and the southern section. The northern section includes approximately 4 miles of Muddy Creek, extending from the proposed dam site to an existing irrigation control structure, approximately 0.25 miles above the confluence of Cow Gulch with Muddy Creek. The southern section includes approximately 2.5 miles of Muddy Creek, extending from the existing irrigation control structure above the confluence of Cow Gulch to the southern boundary 


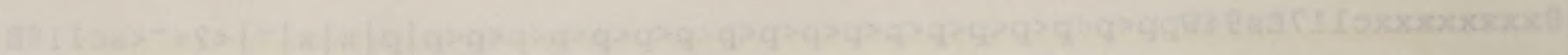

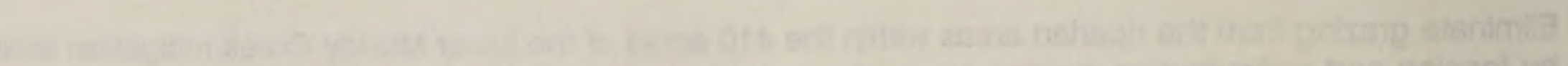

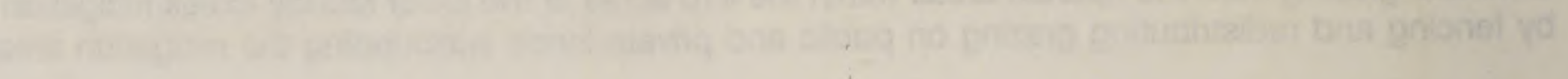

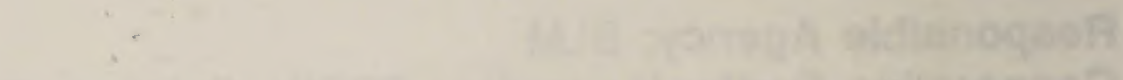
20. (4)

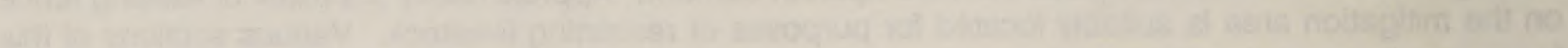

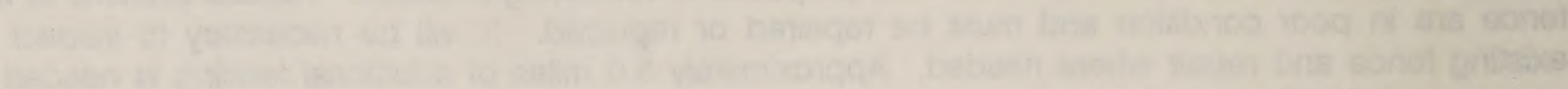

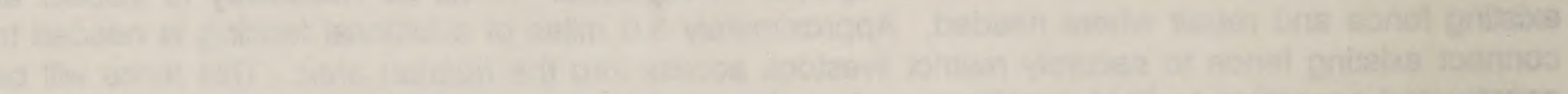
20.20

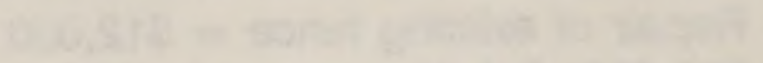




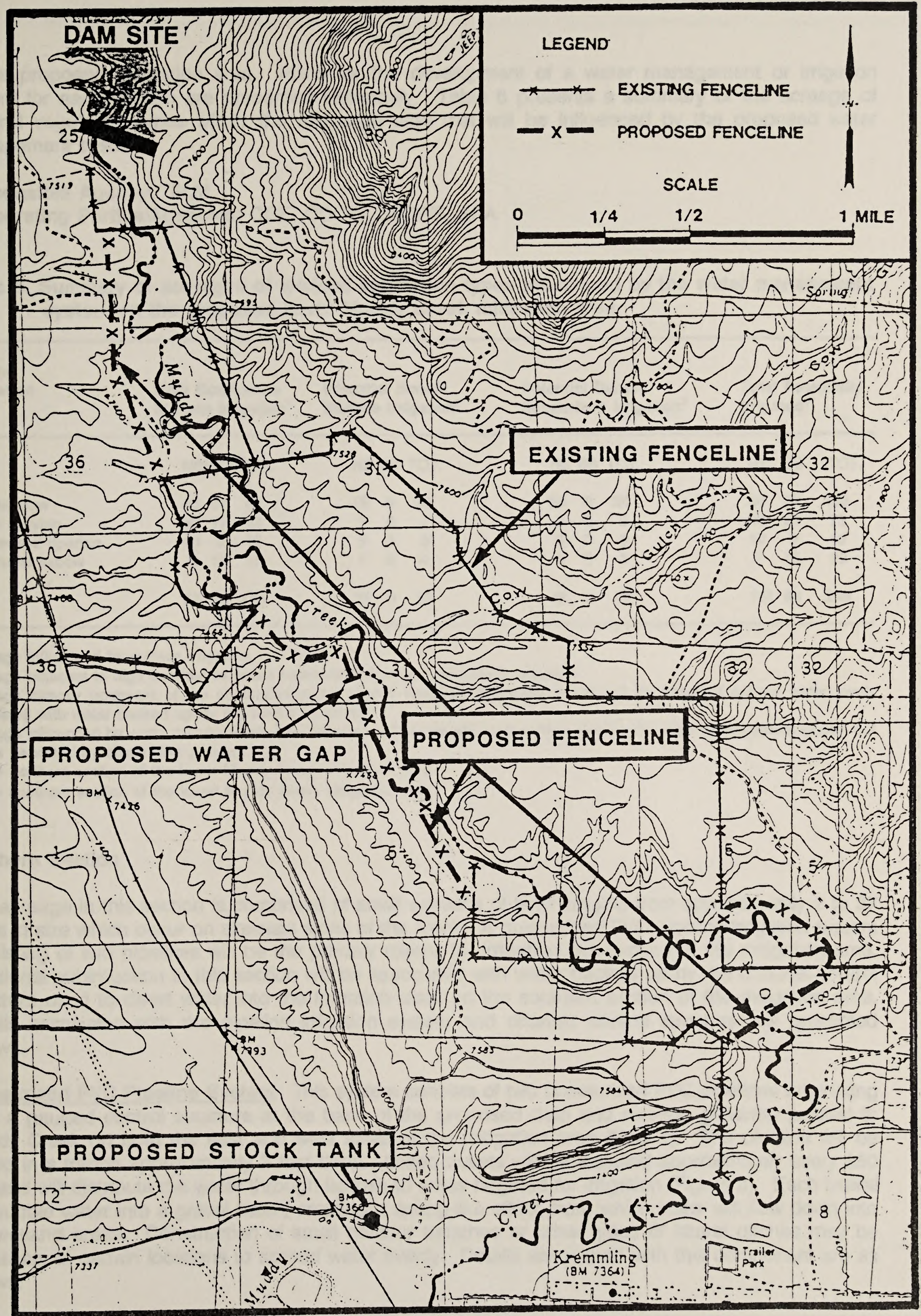

Figure 2. Location of Existing Fenceline and Proposed New Fence for the Lower Muddy Creek Mitigation Area. 


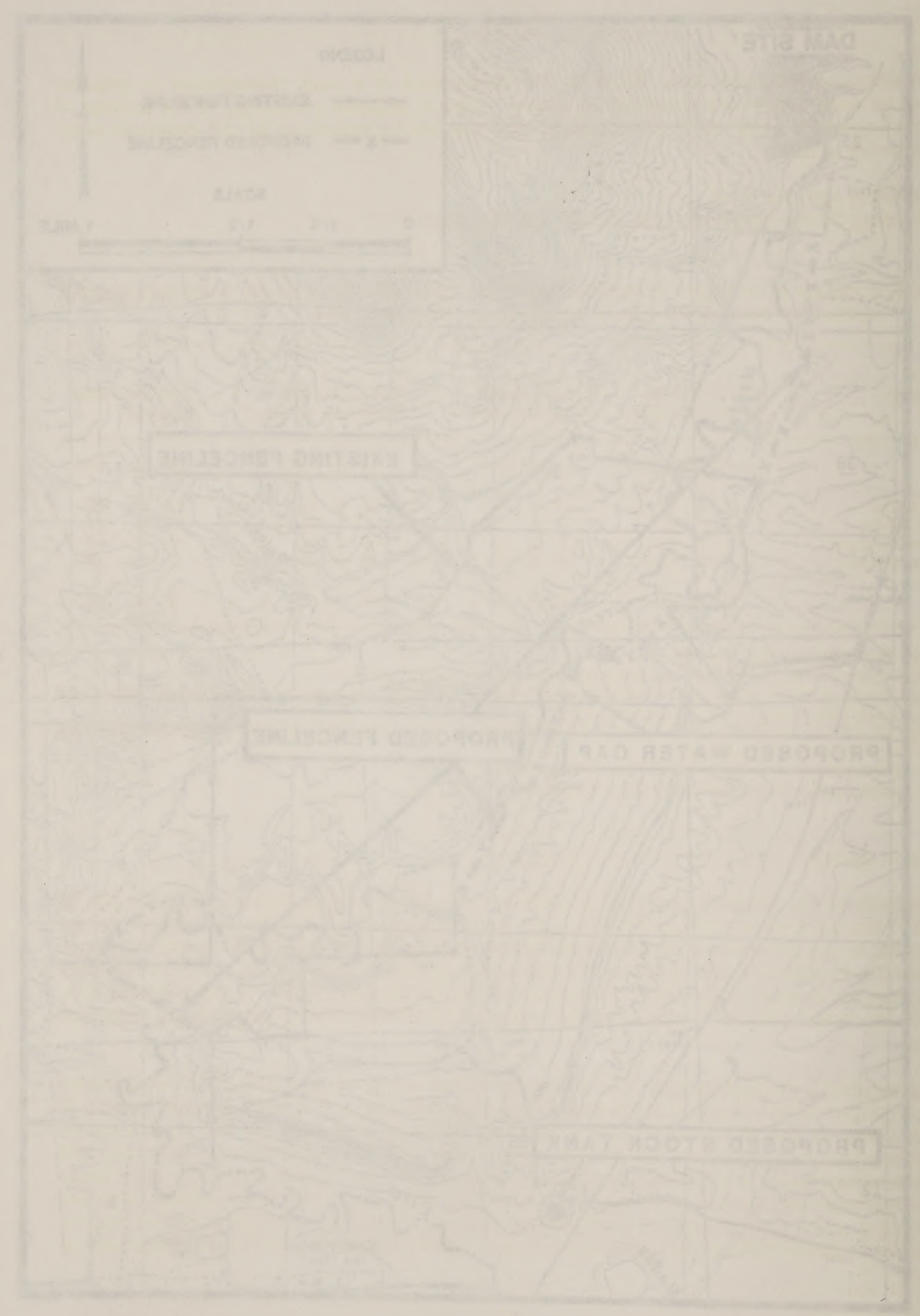

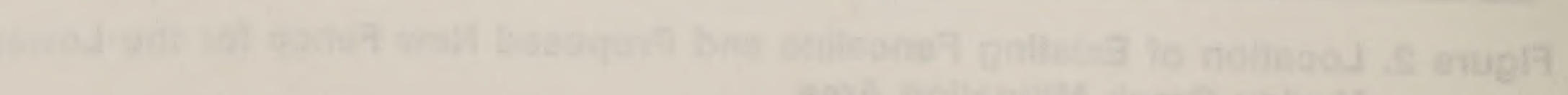

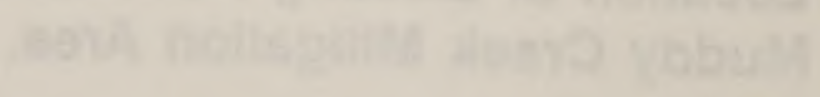


of the proposed mitigation area. Plans for the development of a water management or irrigation system for each section are presented separately. Table 6 presents a summary of the acreage of wetland vegetation types within the mitigation area that will be influenced by the proposed water management system.

Responsible Agency: BLM

Cooperating Parties/Agencies: COE, CDOW, USFWS, EPA

Table 6. Summary of acreages of wetland vegetation types influenced by the water management system on the proposed lower Muddy Creek mitigation area.

\begin{tabular}{|c|c|c|c|c|c|c|c|c|c|c|c|}
\hline \multirow[t]{2}{*}{$\begin{array}{l}\text { Wetland } \\
\text { Vegetation } \\
\text { Type }\end{array}$} & \multicolumn{2}{|c|}{$\begin{array}{l}\text { High Confidence } \\
\text { Surface Irrigation' }\end{array}$} & \multicolumn{3}{|c|}{$\begin{array}{l}\text { Potentlal Benefit } \\
\text { Surface Irrigation }\end{array}$} & \multicolumn{3}{|c|}{$\begin{array}{l}\text { Potential Benefit } \\
\text { Subsurface Irrigation }{ }^{3}\end{array}$} & \multicolumn{3}{|c|}{$\begin{array}{l}\text { Total Potentially } \\
\text { Irrigated } 4\end{array}$} \\
\hline & $N S^{5} S S$ & 'TOT. & NS & SS & TOT. & NS & SS & TOT. & NS & SS & TOT \\
\hline Wet meadow & 4537 & 82 & 15 & 0 & 15 & 36 & 0 & 36 & 96 & 37 & 133 \\
\hline Willow riparian & 3227 & 59 & 7 & 0 & 7 & 9 & 0 & 9 & 48 & 27 & 75 \\
\hline Cottonwood riparian & 109 & 19 & 0 & 0 & 0 & 0 & 0 & 0 & 10 & 9 & 19 \\
\hline Ephemeral oxbow & 015 & 15 & 4 & 0 & 4 & 3 & 0 & 3 & 7 & 15 & 22 \\
\hline Total & 8788 & 175 & 26 & 0 & 26 & 48 & 0 & 48 & 161 & 88 & 249 \\
\hline
\end{tabular}

'Acreage influenced by surface irrigation.

${ }^{2}$ Acreage adjacent to high confidence areas potentially influenced by surface irrigation.

${ }^{3}$ Acreage directly upstream of the channel/irrigation control structure potentially influenced by elevated ground water levels associated with water backed up by the control structure.

${ }^{4}$ Acreage influenced by water management. Approximately 141 acres will not be influenced by the water management system but will be benefited by eliminating grazing.

${ }^{5} \mathrm{NS}=$ northern section of the lower Muddy Creek mitigation area.

'SS = southern section of the lower Muddy Creek mitigation area.

\section{Northern Section}

The acreage in this section is comprised of small sections of land ranging from approximately 2 to 27 acres in size which occur on alternate sides of the creek. A pressurized PVC pipeline irrigation system consisting of two pipelines will be the primary means for irrigating this section of the mitigation area. Additional subirrigation in this section will be associated with water backed up by the channel control structure used to divert water into the irrigation ditch on the southern section of the mitigation area. Details associated with the pipeline irrigation system and channel control structure are presented below.

Pressurized PVC Pipeline System. This system consists of two pressurized PVC pipelines originating from a gauged control structure at the base of the proposed dam and running generally parallel to Muddy Creek on both the east and west sides of the mitigation area (Map 1). The pipeline will be buried in a trench approximately 3 feet deep. Gated outlets will be installed approximately every 250 feet and will distribute the water through laterals to areas targeted for irrigation (Figure 3). Each lateral will bubble water into a gravel basin, creating a spring-like effect, from which water will flow down into the wetland areas. Construction of small contour trenches or other types of lateral ditches may be necessary in certain locations to spread water evenly. Details associated with this component are as follows: 


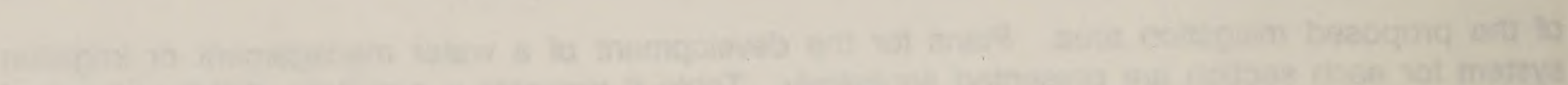

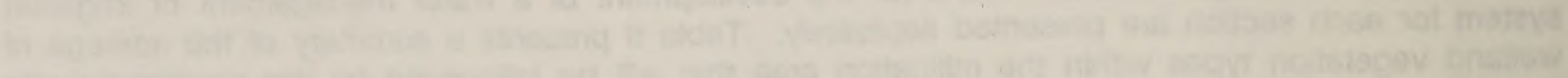
The

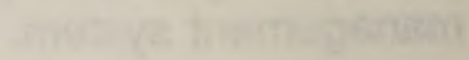

araran 


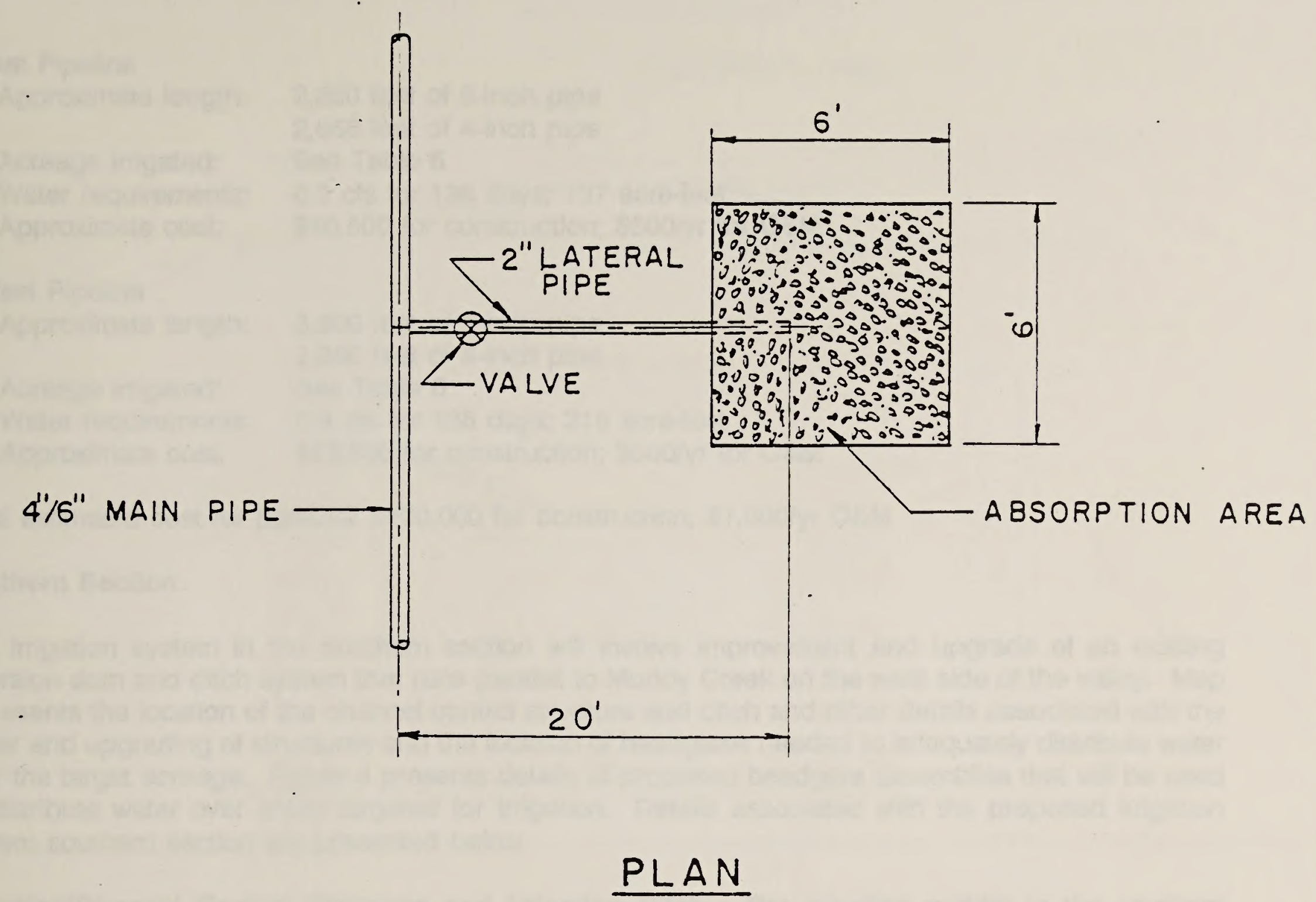

4"/6"MAIN PIPE

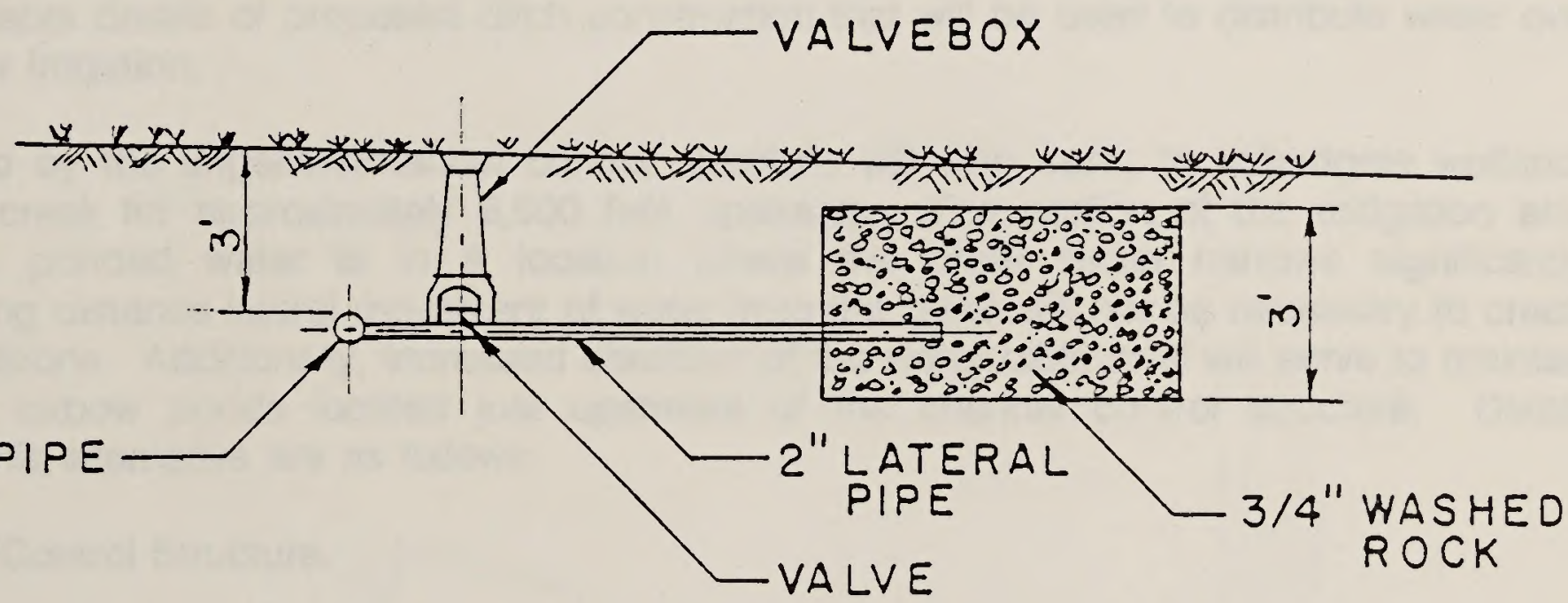

ELEVATION

\section{TYPICAL PIPELINE CONSTRUCTION}

Figure 3 


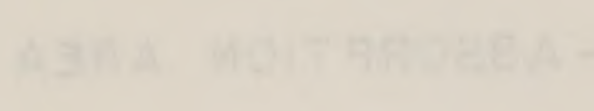

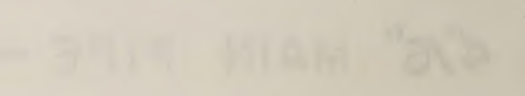

$14=2$

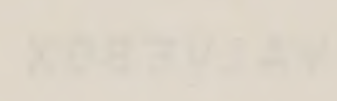

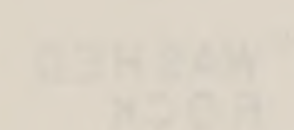
(1)

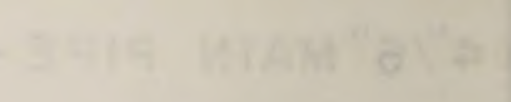

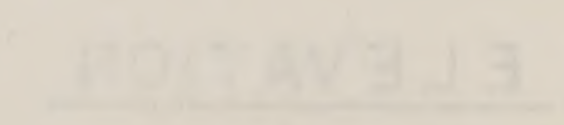

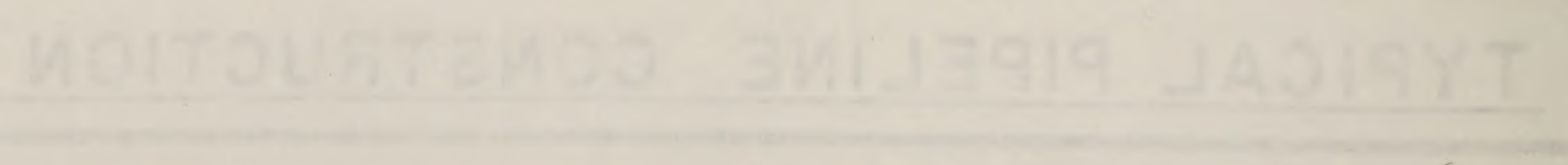

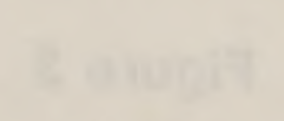


- East Pipeline

Approximate length: 2,350 feet of 6 -inch pipe

2,650 feet of 4 -inch pipe

Acreage irrigated: $\quad$ See Table 6

Water requirements: 0.5 cfs for 138 days; 137 acre-feet

Approximate cost: $\quad \$ 40,500$ for construction; $\$ 500 / y r$ for O\&M

- West Pipeline

Approximate length: 3,900 feet of 6 -inch pipe

Acreage irrigated: See Table 6

Water requirements: 0.8 cfs for 138 days; 219 acre-feet

Approximate cost: $\quad \$ 59,500$ for construction; $\$ 500 / y$ for O\&M

Total estimated cost for pipeline: $\$ 100,000$ for construction; $\$ 1,000 / y r$ O\&M

\section{Southern Section}

The irrigation system in the southern section will involve improvement and upgrade of an existing diversion dam and ditch system that runs parallel to Muddy Creek on the west side of the valley. Map 2 presents the location of the channel control structure and ditch and other details associated with the repair and upgrading of structures and the location of headgates needed to adequately distribute water over the target acreage. Figure 4 presents details of proposed headgate assemblies that will be used to distribute water over areas targeted for irrigation. Details associated with the proposed irrigation system southern section are presented below.

Irrigation/Channel Control Structure and Irrigation Ditch. The irrigation system in the southern section will utilize an existing diversion dam and ditch system that runs parallel to Muddy Creek on the west side of the valley. The channel control structure will be constructed using large size rip rap and will be 2 to 3 feet in height. Details of a typical channel control structure are presented in Figure 5. Figure 6 presents details of proposed ditch construction that will be used to distribute water over areas targeted for irrigation.

Water backed up by the irrigation/channel control structure will also serve to subirrigate wetlands adjacent to the creek for approximately 6,500 feet upstream. The portion of the mitigation area affected by this ponded water is in a location where the creek basin narrows significantly. Consequently, long distance lateral movement of water from the creek will not be necessary to create subirrigated conditions. Additionally, increased elevation of the water table level will serve to maintain water in several oxbow ponds located just upstream of the channel control structure. Details associated with this alternative are as follows:

- Irrigation Ditch/Control Structure.

Approximate length: Acreage irrigated: Water requirements: Approximate cost:
13,200 feet of ditch

See Table 6

1.1 cfs for 138 days; 301 acre-feet/yr $\$ 18,000$ for ditch repair and upgrade

$\$ 6,100$ for construction of channel control structure 


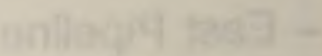

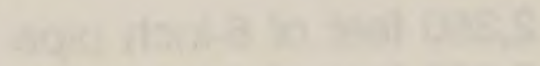

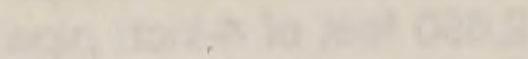

Cathat

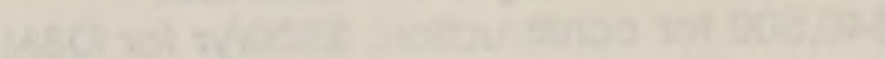

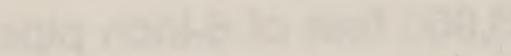

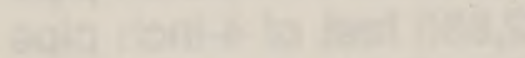

年

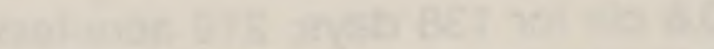

- aramen asmikciogh

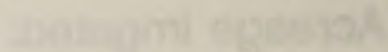

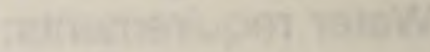

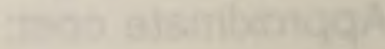

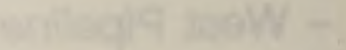

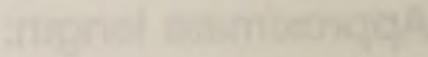

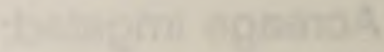

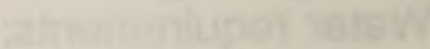

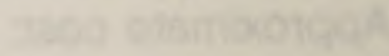

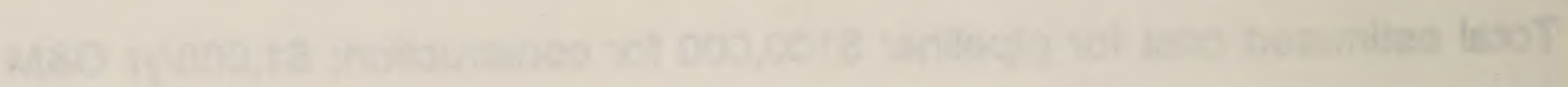

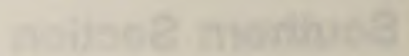

4T:

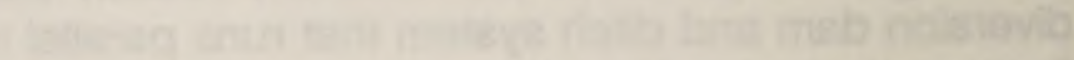
(15)

(15)

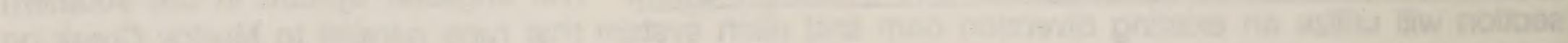

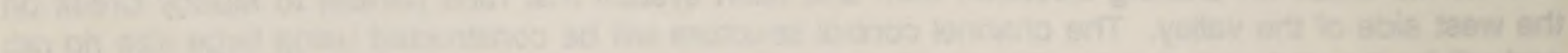

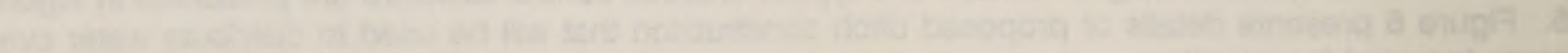
thater.

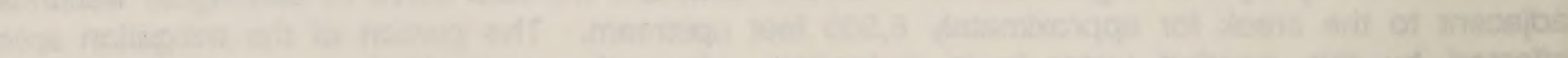
Crate Chach (15)

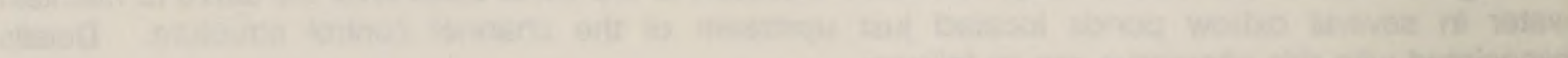

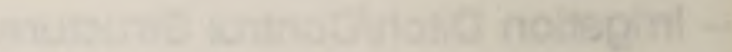

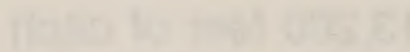

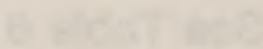

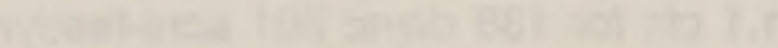
a

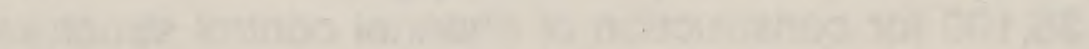

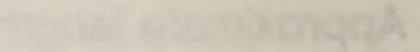

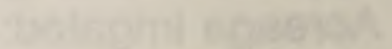

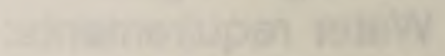

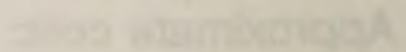



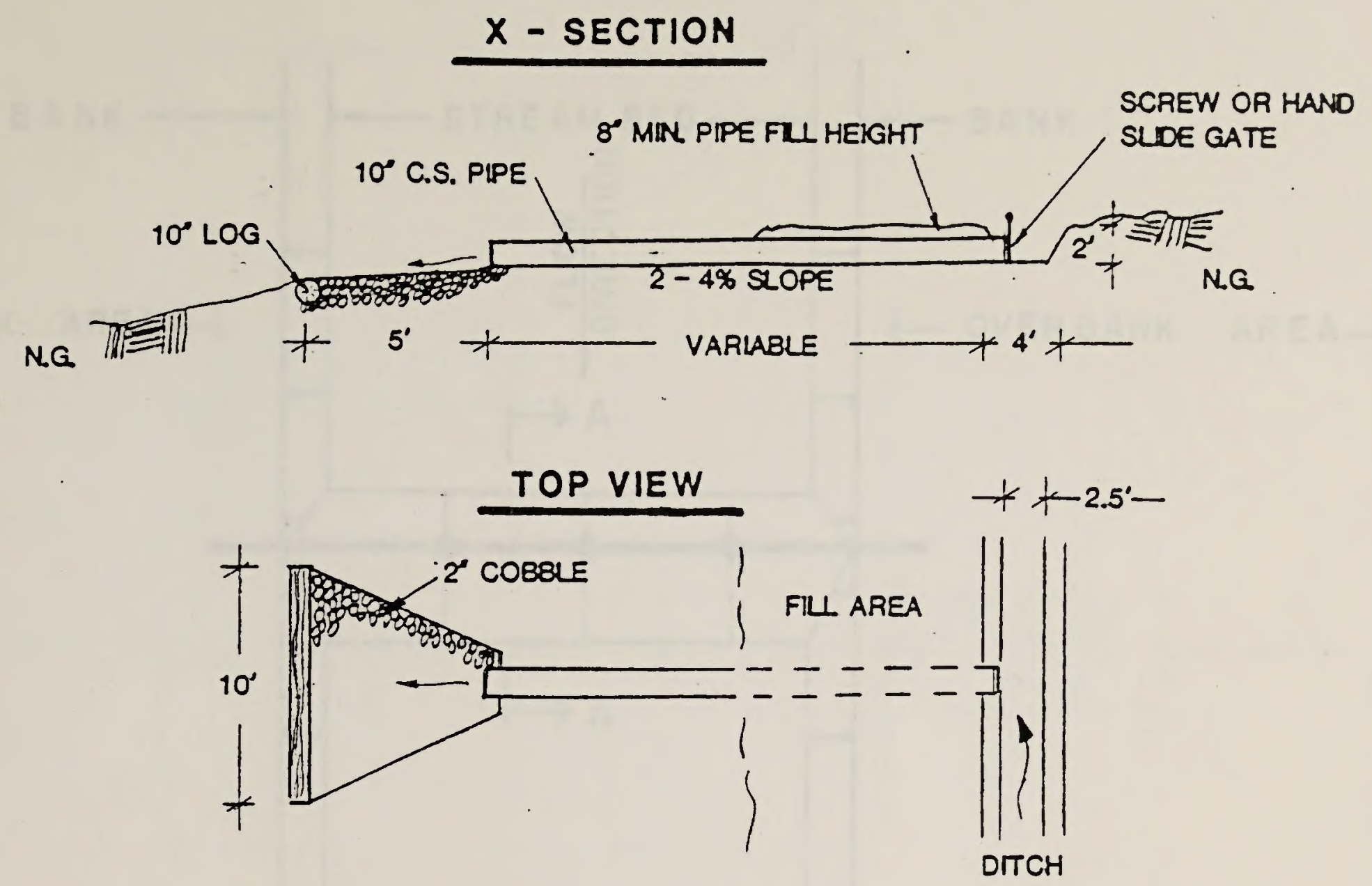

PROPOSED SCREW OR HAND SLIDE GATE DETAIL

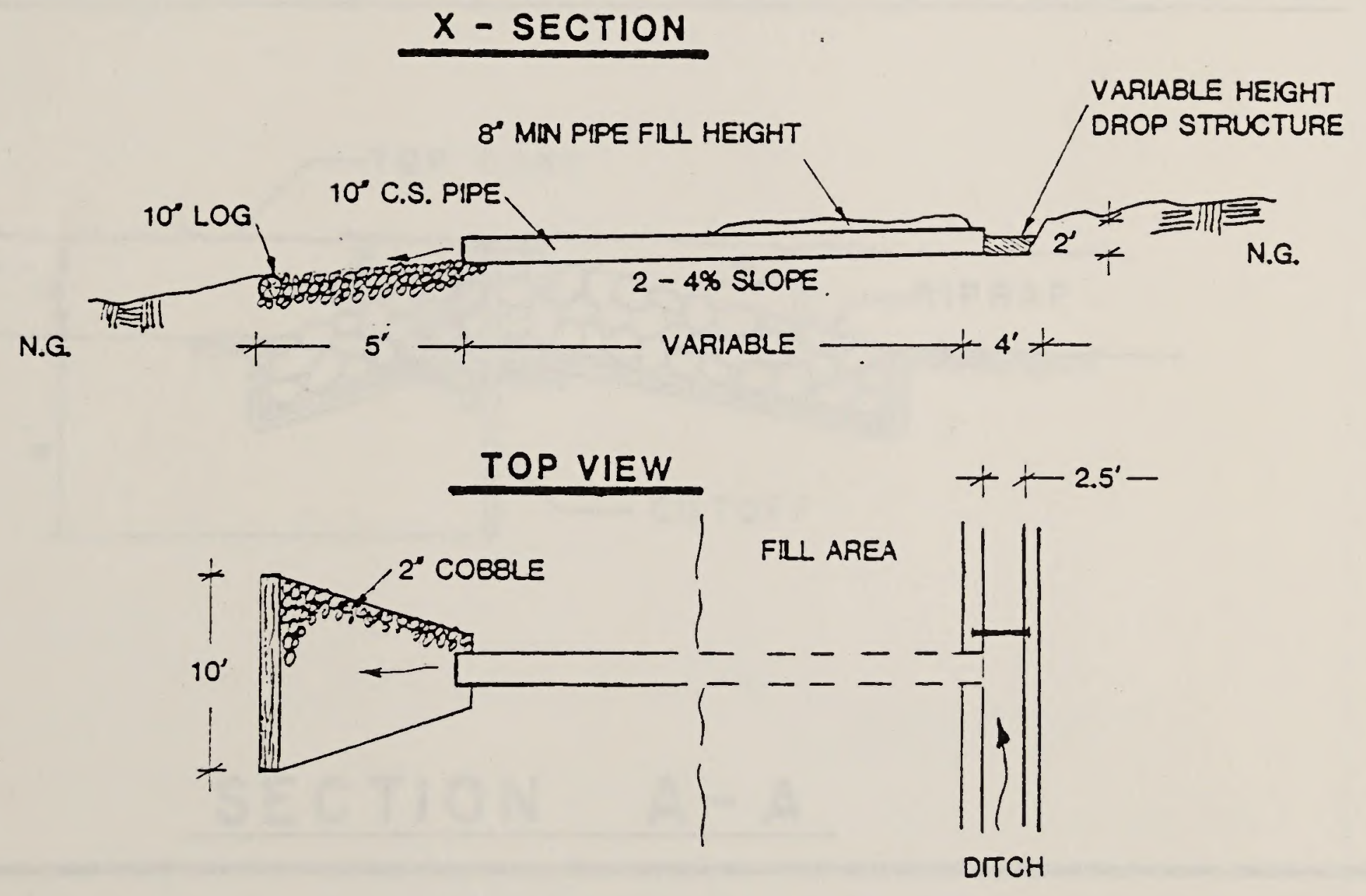

PROPOSED DROP STRUCTURE \& TOP SPILL GATE DETAIL

Figure 4. Proposed Head Gate \& Delivery System from the Irrigation Ditch on the Southern Section of the Lower Muddy Creek Mitigation Area. 


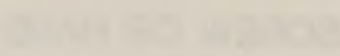
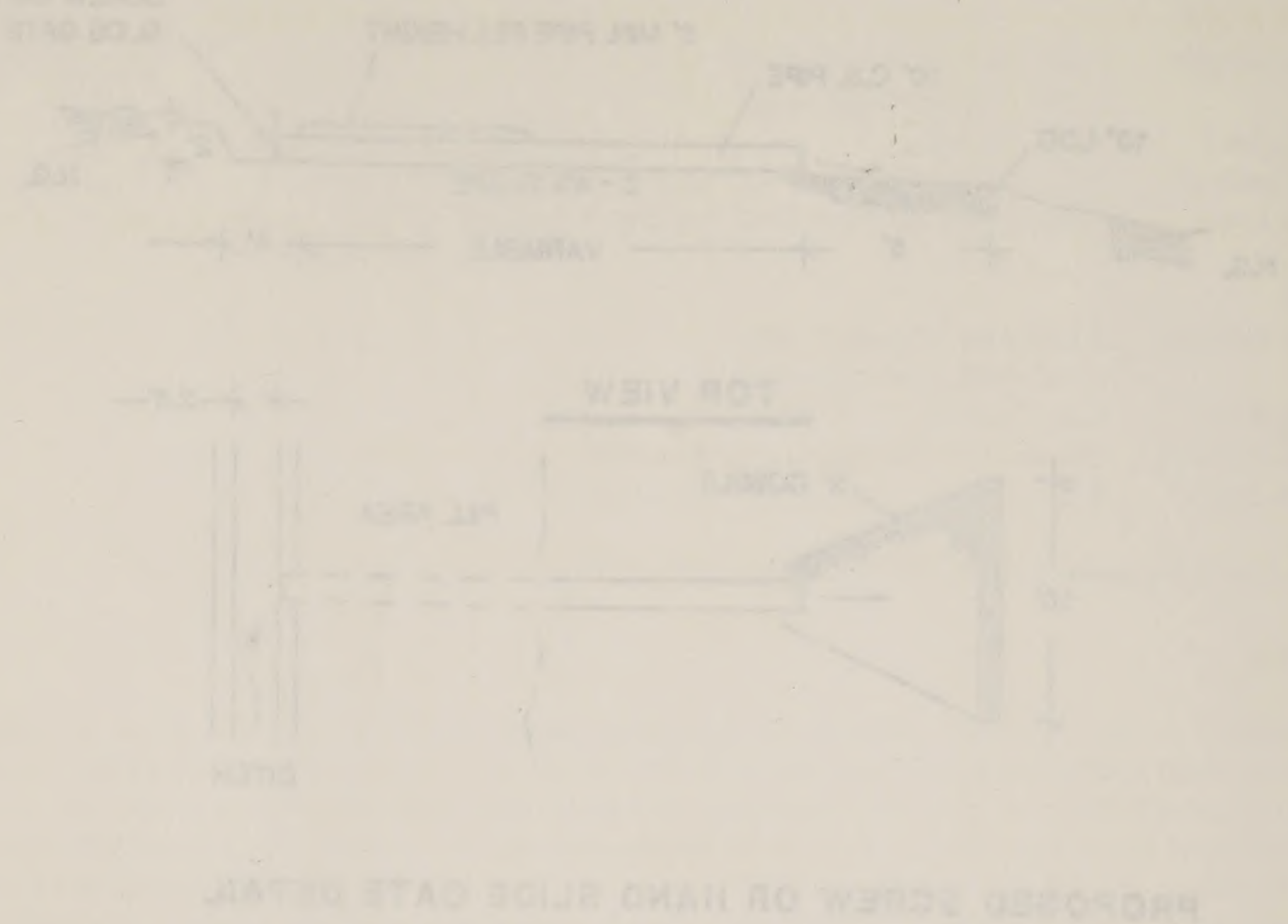

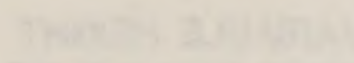

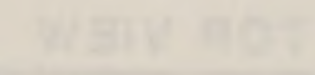
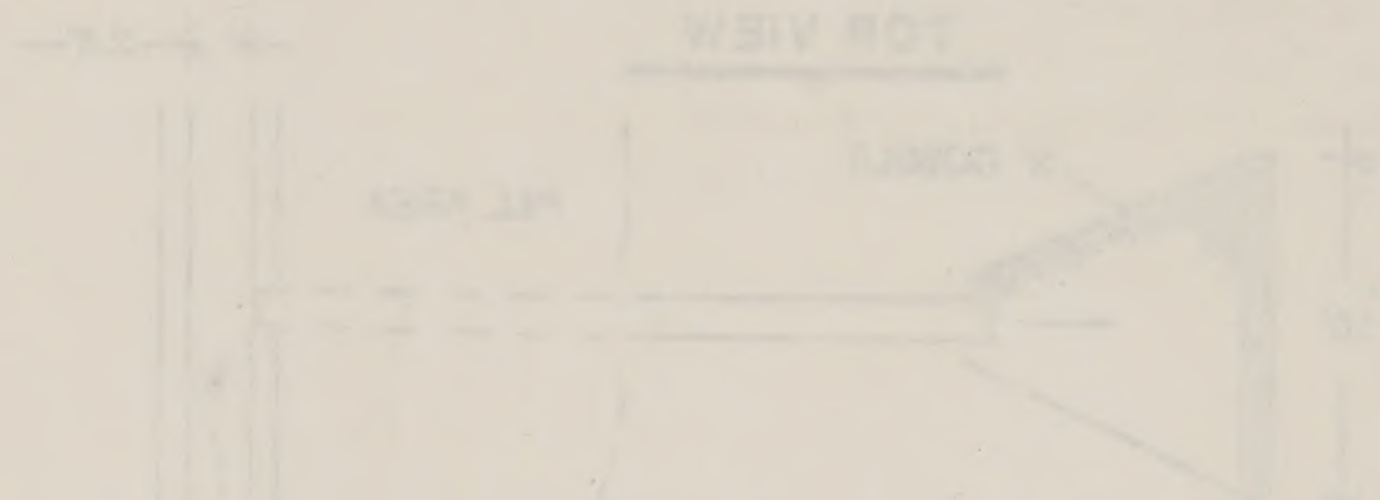

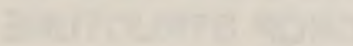

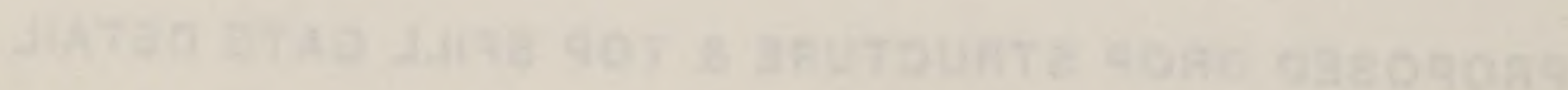

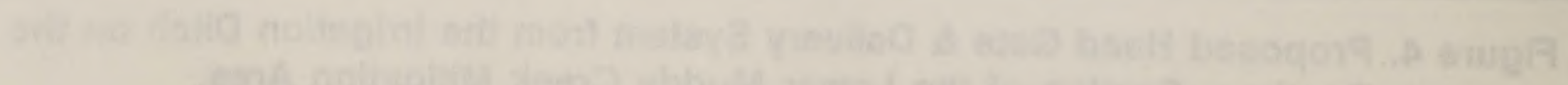

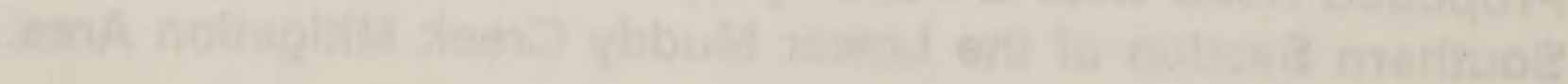




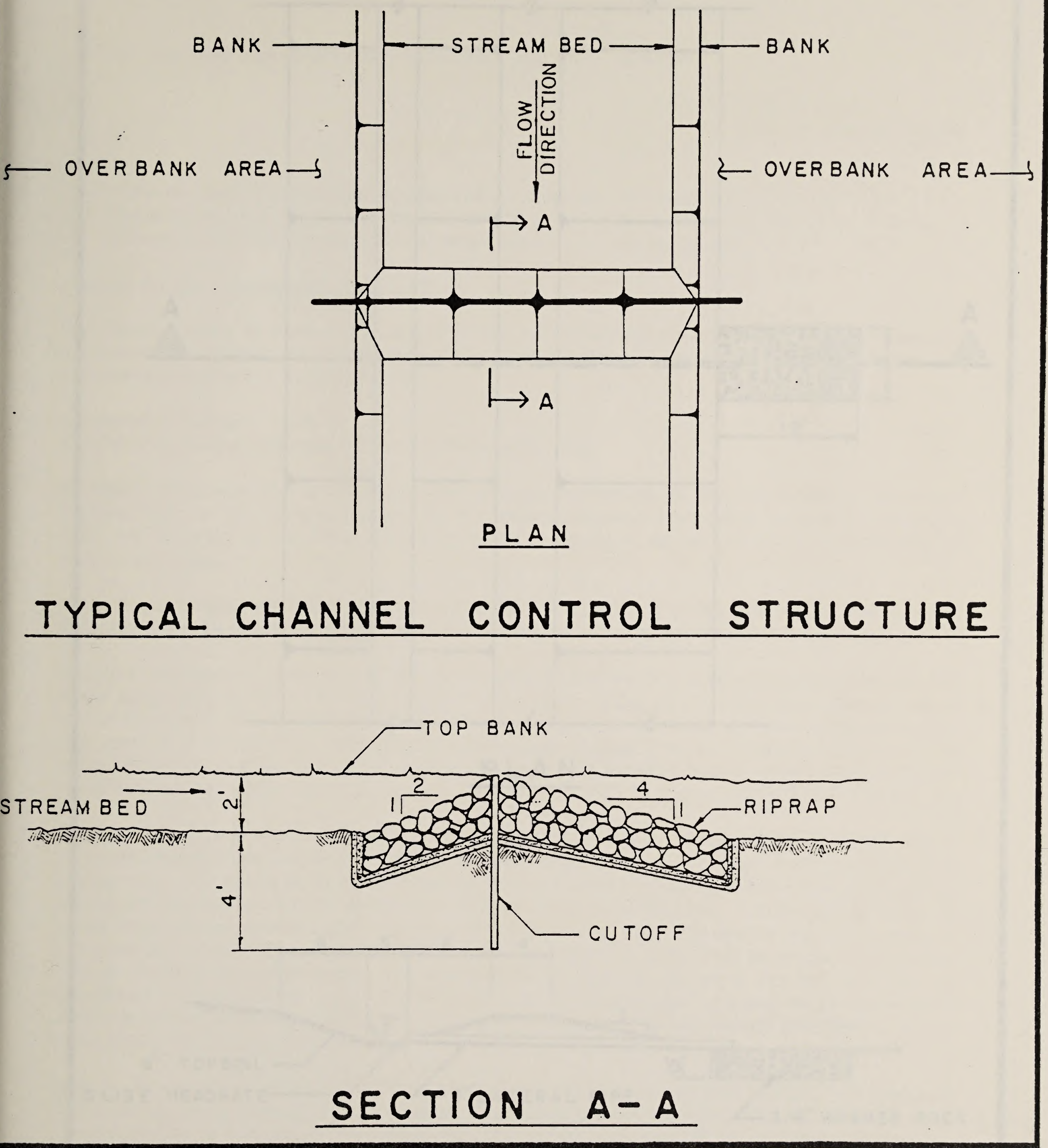

Figure 5 


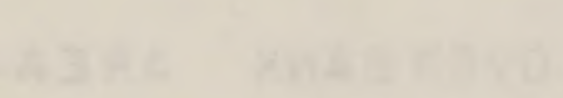
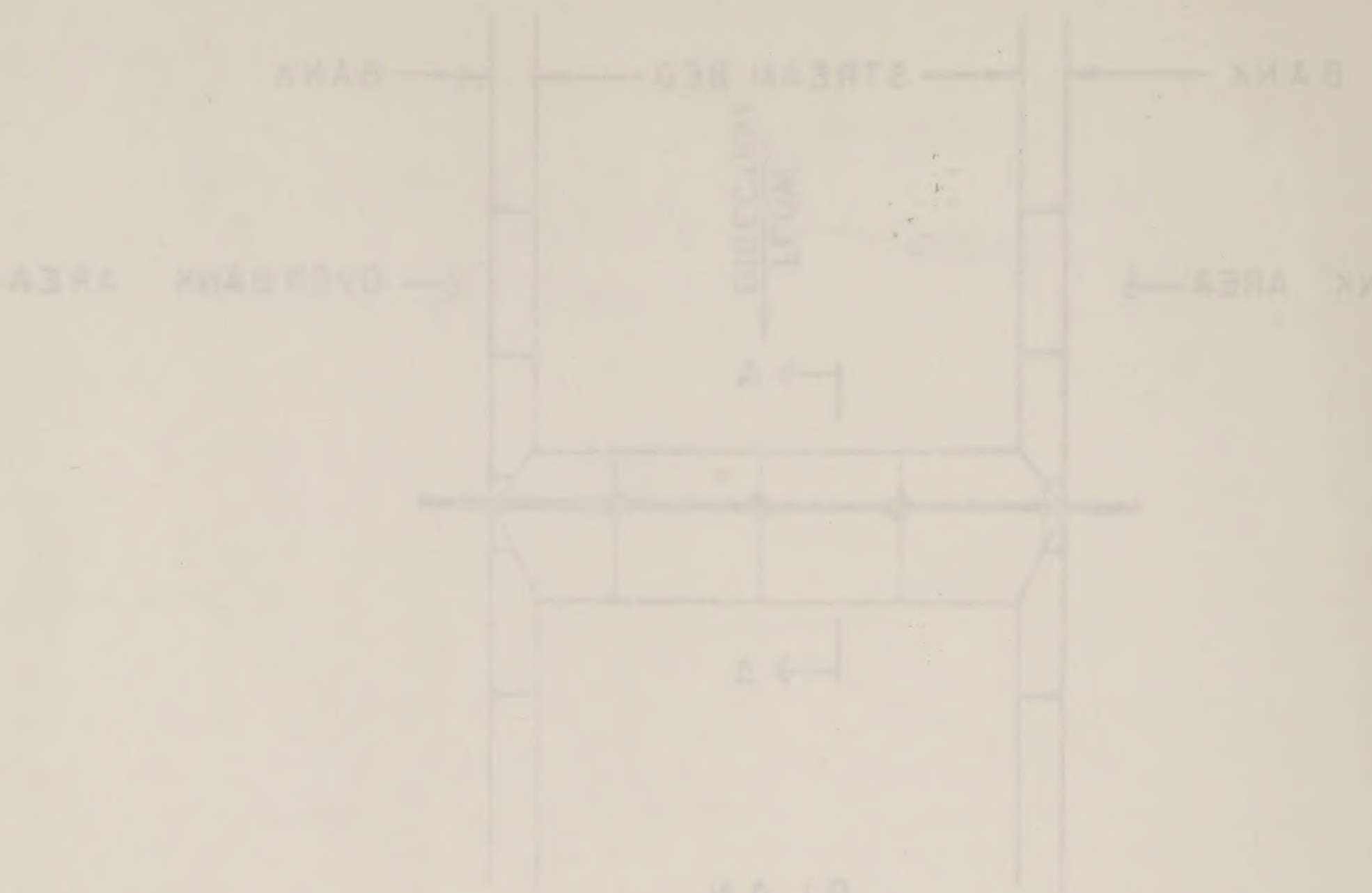

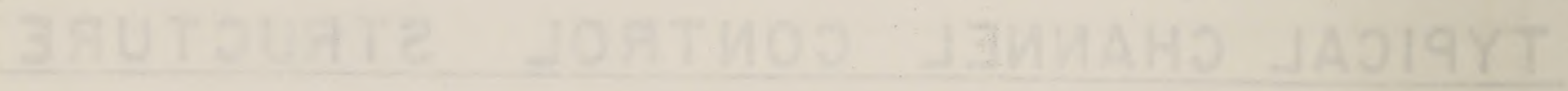

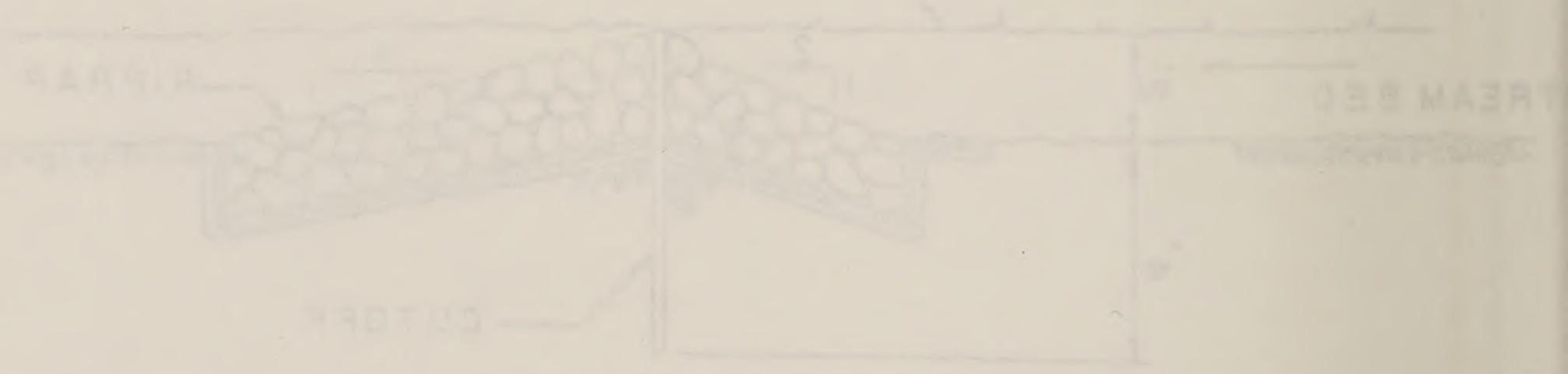

\section{$2-4=1017932$}




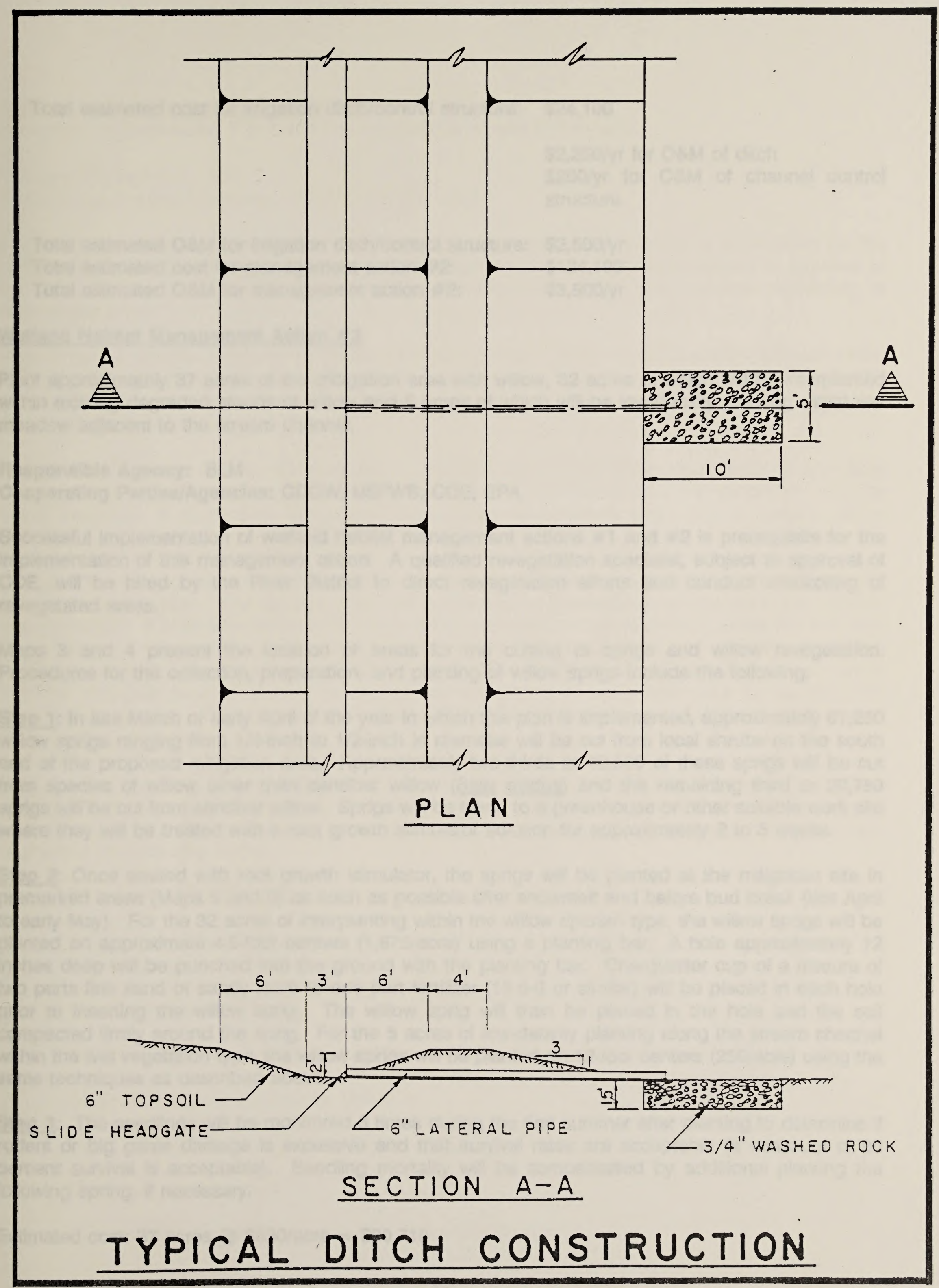

Figure 6 


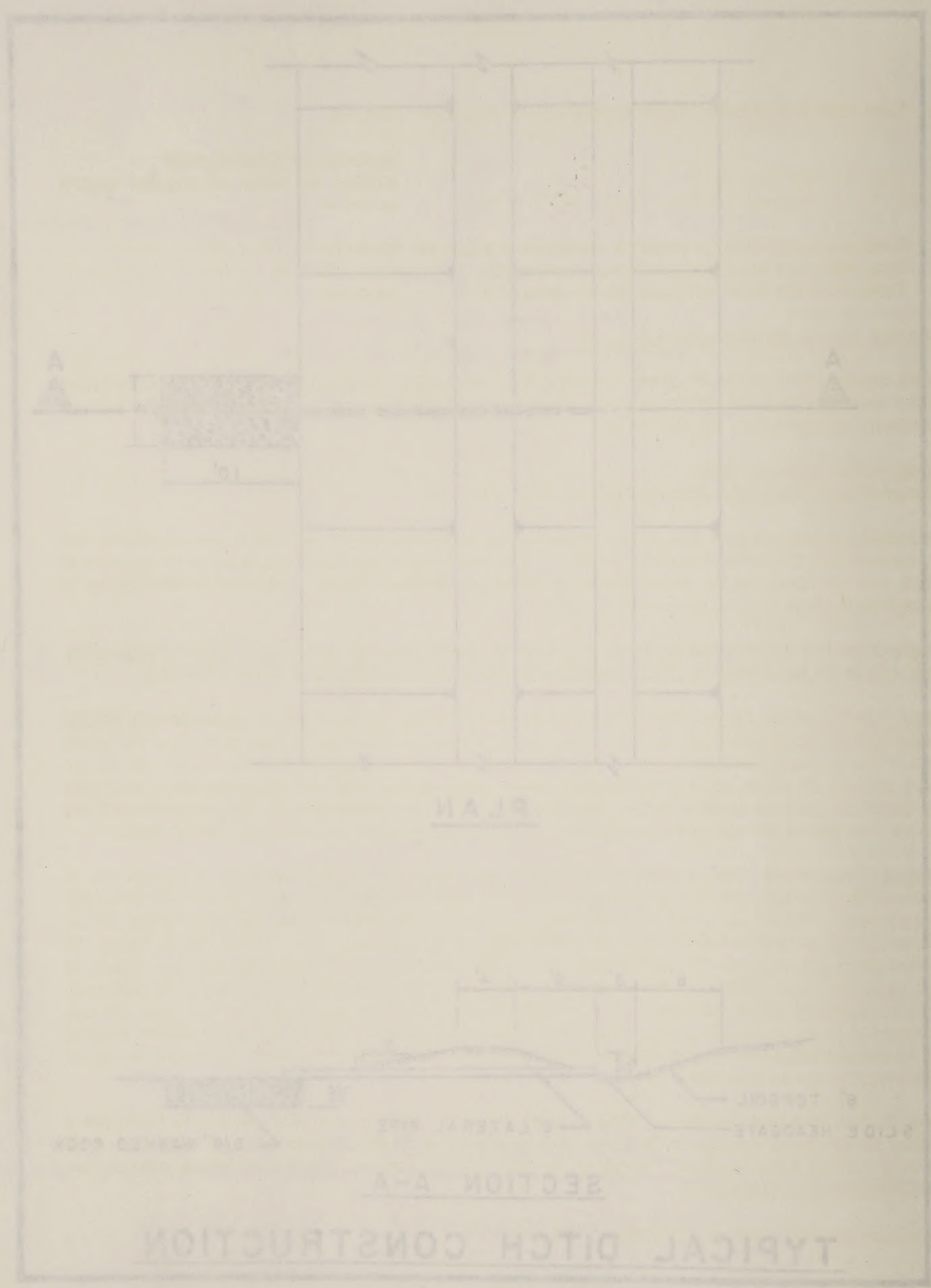

간. 
Total estimated cost for irrigation ditch/control structure: $\$ 24,100$

$\$ 2,250 / y r$ for O\&M of ditch $\$ 250 / y r$ for O\&M of channel control structure

Total estimated O\&M for irrigation ditch/control structure: Total estimated cost for management action \#2:

$\$ 2,500 / y r$

Total estimated O\&M for management action \#2:

\section{Wetland Habitat Management Action \#3}

Plant approximately 37 acres of the mitigation area with willow, 32 acres of which will be interplanted within existing degraded stands of willow and 5 acres of which will be low-density planting within wet meadow adjacent to the stream channel.

Responsible Agency: BLM

Cooperating Parties/Agencies: CDOW, USFWS, COE, EPA

Successful implementation of wetland habitat management actions \#1 and \#2 is prerequisite for the implementation of this management action. A qualified revegetation specialist, subject to approval of COE, will be hired by the River District to direct revegetation efforts and conduct monitoring of revegetated areas.

Maps 3 and 4 present the location of areas for the cutting of sprigs and willow revegetation. Procedures for the collection, preparation, and planting of willow sprigs include the following:

Step 1: In late March or early April of the year in which this plan is implemented, approximately 61,250 willow sprigs ranging from $1 / 4$-inch to $1 / 2$-inch in diameter will be cut from local shrubs on the south end of the proposed mitigation area. Approximately two-thirds or 40,500 of these sprigs will be cut from species of willow other than sandbar willow (Salix exidua) and the remaining third or 20,750 sprigs will be cut from sandbar willow. Sprigs will be taken to a greenhouse or other suitable work site where they will be treated with a root growth stimulator solution for approximately 2 to 3 weeks.

Step 2: Once treated with root growth stimulator, the sprigs will be planted at the mitigation site in premarked areas (Maps 5 and 6) as soon as possible after snowmelt and before bud break (late April to early May). For the 32 acres of interplanting within the willow riparian type, the willow sprigs will be planted on approximate 4.5-foot centers (1,875/acre) using a planting bar. A hole approximately 12 inches deep will be punched into the ground with the planting bar. One-quarter cup of a mixture of two parts fine sand or sandy loam to one part fertilizer (18-6-6 or similar) will be placed in each hole prior to inserting the willow sprig. The willow sprig will then be placed in the hole and the soil compacted firmly around the sprig. For the 5 acres of low-density planting along the stream channel within the wet vegetation type, the willow sprigs will be planted on 12-foot centers (250/acre) using the same techniques as described above.

Step 3: The seedlings will be monitored 3 times during the first summer after planting to determine if rodent or big game damage is excessive and that survival rates are acceptable (a minimum of 80 percent survival is acceptable). Seedling mortality will be compensated by additional planting the following spring, if necessary.

Estimated cost: 37 acres @ $\$ 830 /$ acre $=\$ 30,710$ 


\section{Wetland Habitat Management Action \#4}

Revegetate approximately 7 acres of the mitigation area with cottonwood.

\section{Responsible Agency: BLM \\ Cooperating Partles/Agencies: CDOW, USFWS, COE}

Successful implementation of wetland habitat management actions \#1 and \#2 is prerequisite for the implementation of this management action. A qualified revegetation specialist, subject to approval of the COE, will be hired by the District to direct revegetation efforts and conduct monitoring of revegetated areas.

Maps 3 and 4 identify locations for cottonwood revegetation. Cottonwood plantings will take place within a variety of vegetation types but every effort will be made to minimize the use of wet meadow for cottonwood planting. Procedures for the collection, preparation, and planting of cottonwood seedlings are described below:

Step 1: During the fall before implementation of this plan, obtain 770 cottonwood seedlings from local cottonwood stands that will be made ready to plant during the following spring concurrent with the willow plantings. If local stock is not available suitable containerized stock from a nursery will be obtained.

Step 2: The planting will be accomplished as soon as possible after snowmelt and before bud break (late April to early May). The seedling stock will be planted on approximate 20-foot centers (110/acre) using a spade. A hole approximately 6 inches deep and wide enough to accommodate the root wad of the container with approximately $1 / 2$ to 1 inch of space between the root wad and the edge of the hole will be dug into the ground with the spade. One cup of a mixture of two parts fine sand or sandy loam to one part fertilizer (18-6-6 or similar) will be placed in each hole prior to inserting the cottonwood seedling. The cottonwood seedling will then be place in the hole and the soil compacted firmly around the seedling.

Step 3: The seedlings will be monitored 3 times during the first summer after planting to determine whether excessive rodent or big game damage has occurred and whether survival rates are acceptable (a minimum of 60 percent survival is acceptable). Seedling mortality will be compensated by additional planting the following spring.

Estimated cost for acquisition and transplant of nursery stock:

Acquisition of seedlings from nursery $\$ 700$

Shipping costs $=$ not determined $\$ 1,200$

Labor for planting =60 hrs. @ \$10/hr \$600

Total cost approximately $\$ 2,500$

Estimated cost for acquisition and transplant of native stock:

Acquisition of native seedlings (labor) $=$

$$
190 \text { hours@10/hr \$1,900 }
$$

Labor for planting $=60$ hrs. @ \$10/hr $\$ 600$

Total cost approximately $\quad \$ 2,500$

Total estimated cost for management action \#4: $\$ 2,500$ 


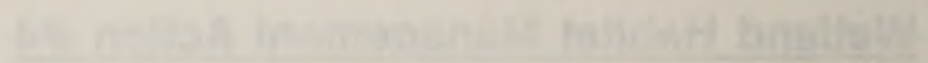

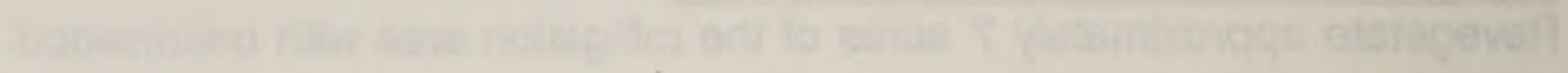

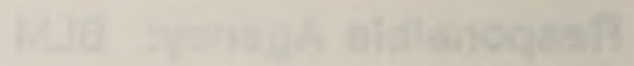

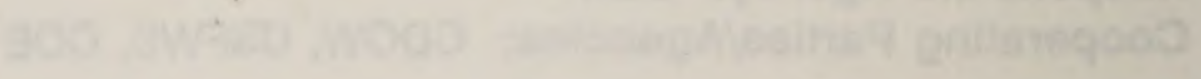

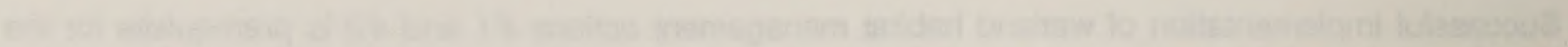

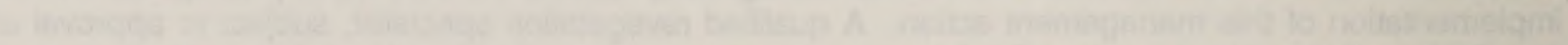
19. Q9.

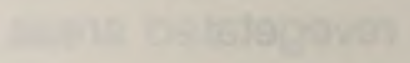

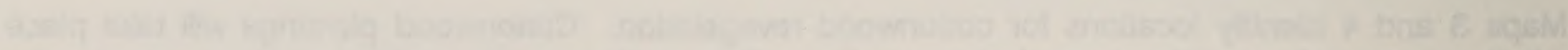

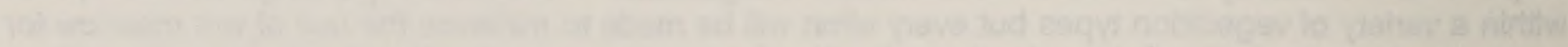

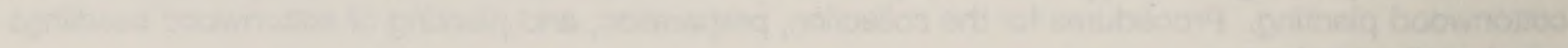

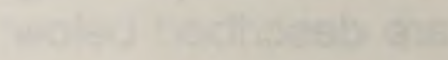

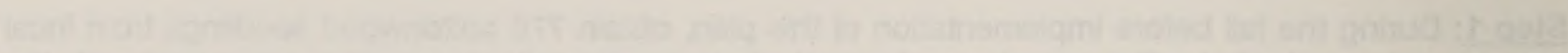

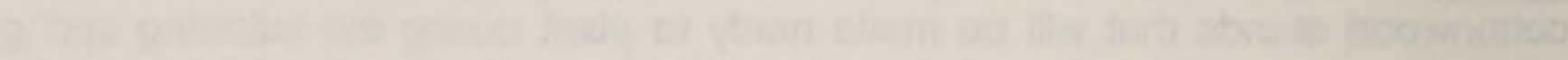

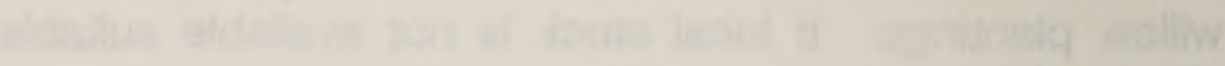




\section{Wetland Habitat Management Action \#5}

Create small ponds in the mitigation area with a total surface area acreage of 8 acres by providing adequate surface irrigation on the mitigation area to maintain standing water in intermittent oxbow channels that are present on the area.

Responsible Agency: BLM

Cooperating Parties/Agencles: CDOW, USFWS, COE, EPA

Over 8 acres of existing oxbow channels and old stream meanders exist on the lower Muddy Creek mitigation area. These channels generally flood during runoff in late May or early June. As water levels in Muddy Creek recede in late June and early July, the majority of these ponds drain or dry up from evaporation and are dry for the remainder of the summer and fall. Irrigation water supplied to the lower Muddy Creek mitigation area via surface irrigation as outlined in wetland habitat management action \#2 will effectively maintain standing water in these ephemeral oxbows, creating pond habitat identical to habitat inundated by the proposed reservoir. Since these oxbow ponds will not exist without water supplied by the proposed management action, loss of pond habitat incurred by the proposed project will be fully mitigated.

No costs specific to this management action are anticipated.

\section{Wetland Habitat Management Action \#6}

Establish and implement a monitoring program to ensure successful implementation of wetland habitat management actions 1 through 5.

Responsibie Agency: BLM

Cooperating Parties/Agencies: CDOW, USFWS, COE, River District

A detailed program designed to monitor changes in wildlife habitat on the mitigation area is essential to ensure full mitigation of impacts to wetland wildlife habitat. Locations of study plots and photo points are presented in Map 5. Proposed tasks included in a monitoring program will be as follows:

1. During the first year, following implementation of the project and once the irrigation systems are in place and operating, visual inspections of all irrigation facilities will be made bimonthly during the operating period to ensure that water is being adequately delivered to target areas. During this time the inspector will make necessary adjustments on control valves or head gates in order to maximize coverage of areas targeted for irrigation and maximize efficiency of water use. The inspector will also be responsible for noting problems with the systems and making recommendations for adjustments or additions to the system such as adding additional outlet valves or headgates, digging lateral ditches or contour trenches, or adding other improvements to the system.

2. During the second and third years, following implementation of the project, visual inspections of all irrigation facilities will be made monthly for the same purposes as described above.

3. Following three years of operation, all major adjustments to the irrigation system should be complete and settings on valves and gates referenced so they can be easily set. Starting on the fourth year of operation the irrigation systems will be inspected immediately after the start of operation in the late spring, then once at a point approximately halfway into the operating schedule for the year, and again 


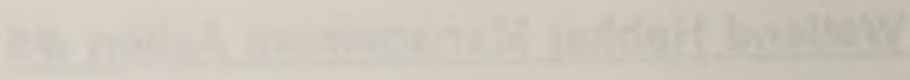

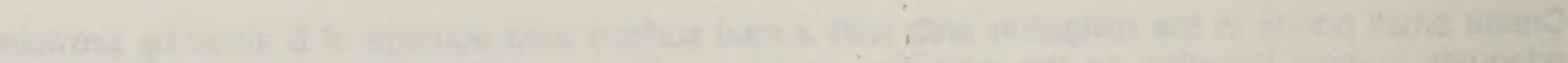

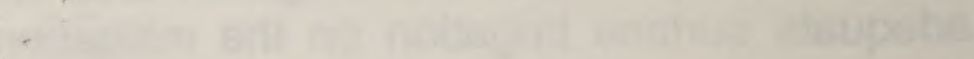

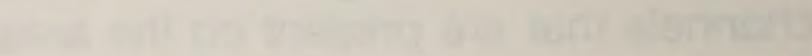

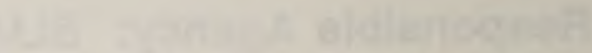
(20)

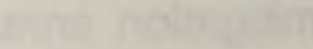

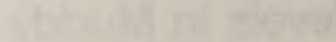

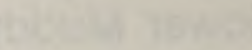

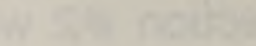

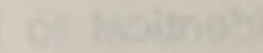
(5)

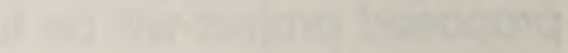

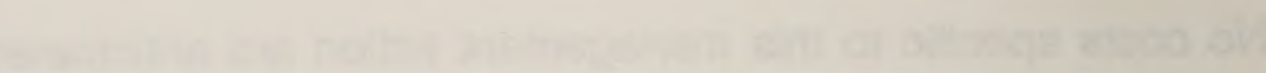

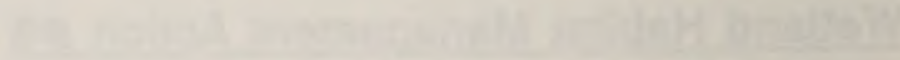

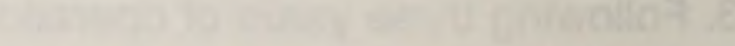

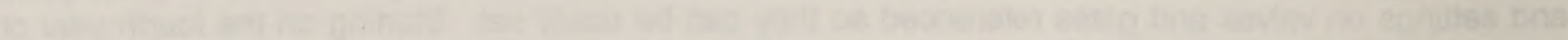

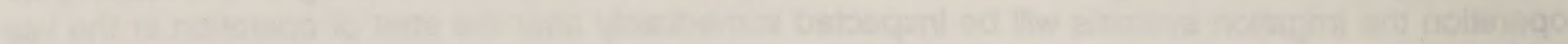

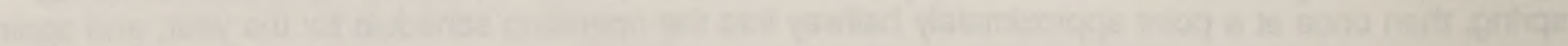


at the end of the operating schedule to check for damage or malfunction. Barring any operational malfunction, all maintenance and cleaning of systems will be conducted during these inspections.

4. Photo monitoring points will be established at six locations on the mitigation area as shown in Map 5. Photo point, compass direction, date, time of day, and type of equipment will be identical for each photo location point to facilitate yearly comparisons. Photographs will be taken from these points annually for the first five years following implementation of this plan and every three years for the life of the project. This will document the progress of the proposed management. Photographs will also be used to document changes resulting from management. Additional photo points could be added as determined by the persons conducting monitoring activities. Copies of photographs will be deposited with the Kremmling Resource Area of the BLM and the COE.

5. Permanent transects, three within each wetland vegetation type, will be established at locations presented in Map 5 . Three wetland vegetation types occur on the mitigation area including wet meadow, willow riparian, and cottonwood/willow riparian, giving a total of nine transects. These will be read once prior to implementation of the mitigation plan and annually for the first five years of the project. After that, they will be read once every six years for the life of the project. Transects will be read during the period from July 15 to July 31. Each transect will consist of a 50-meter line, with end points marked by 3 -foot sections of rebar driven into the ground so that approximately 4 inches remains showing. This rebar will be used to fix the tape while a transect is read. The starting point of the transect will also be marked using a 6-foot metal fencepost driven into the ground until secure. This will aid in locating the transects throughout the life of the project. A photograph will be taken from the starting point of the transect, facing down the transect, each time data is collected. Vegetative parameters read will include herbaceous cover, herbaceous height, shrub height, shrub cover, species diversity, and species composition. A line-intercept method will be used to measure shrub cover. Herbaceous cover, herbaceous height, and species composition will be measured using ocular estimates within 10 one-meter square quadrats placed on alternating sides of the transect, every three meters beginning on the right side at the 3-meter mark. Species diversity will be measured by counting the number of species rooted in each quadrat. Shrub height will be determined by measuring the nearest shrub to the transect at every 3-meter interval. Data collected during monitoring will be deposited with the Kremmling Resource Area of the BLM and the COE Grand Junction office.

Estimated costs are as follows:

Installation of transects and photo monitoring sites: $\$ 7,500$

Initial data collection and photography: $\quad \$ 5,000$

Monitoring program for the life of the project: $\quad \$ 44,000$

Total estimated cost for management action \#6: $\quad \$ 56,500$

\section{WETLAND HABITAT IMPACTS AND ASSOCIATED MANAGEMENT ACTIONS}

WETLAND HABITAT IMPACT \#1: Loss of 20 habitat units associated with wlldlife species represented by the beaver model.

\section{Assoclated Management Actions:}

Wetland habitat management actions \#1, 2, 3, and 6. 


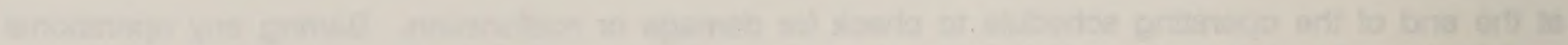

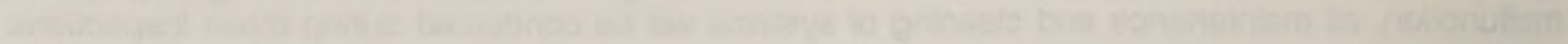

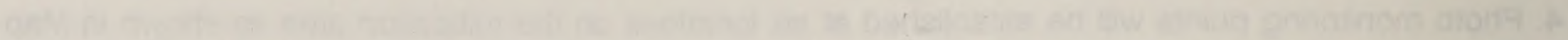

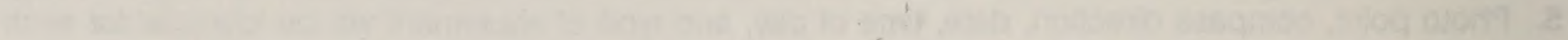
-

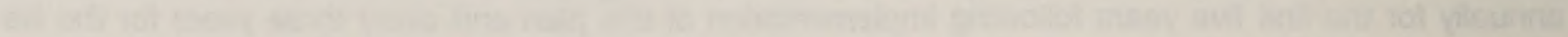

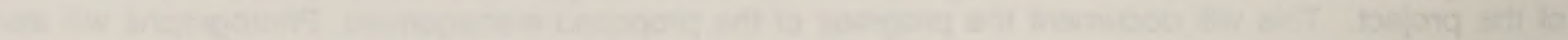
a

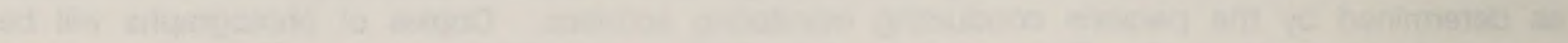

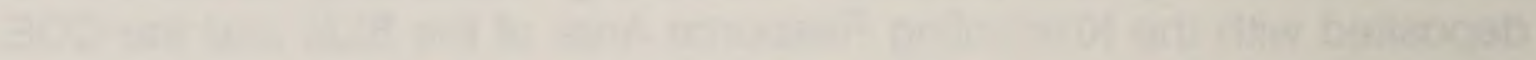
-

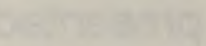
Ther

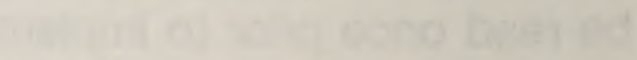

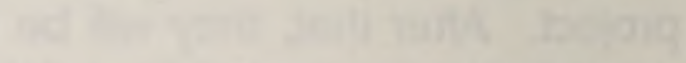

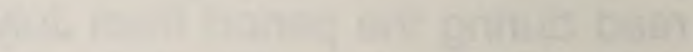
(25)

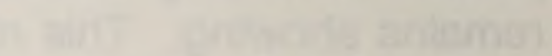

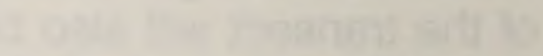

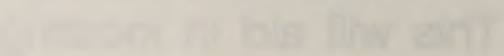

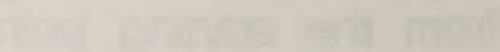

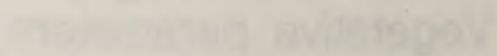
Caras

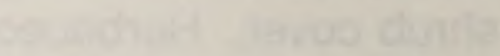

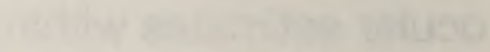
s.

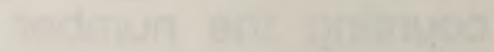

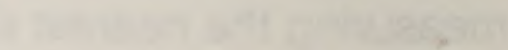

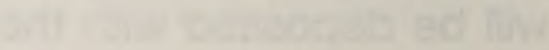

Whata

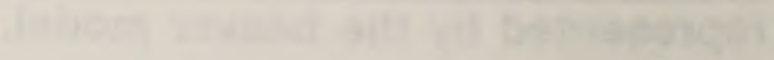

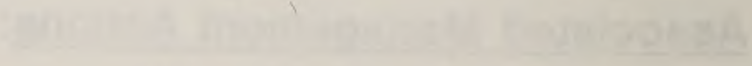

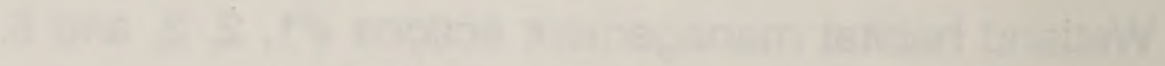




\section{Approach:}

The existing Habitat Suitability Index (HSI) in the willow riparian vegetation type for beaver is 0.526 ( 0.18 for the entire study area) and is projected to reach 0.65 ( 0.23 for the entire study area) through implementation of management actions.

Projected changes in habitat parameters associated with management actions include the following:

1. Hydrophytic shrub cover within the existing 135 acres of willow riparian vegetation type from the current 20 percent to approximately 30 percent through interplanting 32 acres of existing willow stand. An additional 10 percent increase in shrub cover will result from removal of grazing, resulting in a total cover of 40 percent within the willow riparian vegetation type.

\section{Expected Results:}

The management actions will result in a gain of 46 beaver habitat units on the mitigation area, which will fully replace the 20 habitat units lost in the resenoir basin, with a surplus of 26 habitat units.

WETLAND HABITAT IMPACT \#2: Loss of 14 habitat units associated with wildlife species represented by the yellow warbler model.

\section{Associated Management Actions:}

Wetland habitat management actions \#1, 2, 3, 6 .

\section{Approach:}

The existing $\mathrm{HSI}$ in the willow riparian vegetation type for yellow warbler is 0.35 and is projected to reach 0.58 through implementation of management actions.

Projected changes in habitat parameters associated with management actions include the following:

1. Hydrophytic shrub cover within the existing 135 acres of willow riparian vegetation type will increase from the current 20 percent to approximately 30 percent through interplanting 32 acres of existing willow stand. An additional 10 percent increase in shrub cover will result from removal of grazing, resulting in a total cover of 40 percent within the willow riparian vegetation type.

2. Height of hydrophytic shrubs and trees will increase by 10 percent, from $183 \mathrm{~cm}$. to $201 \mathrm{~cm}$., in the mitigation area through removal of grazing.

3. Percentage composition of hydrophytic shrubs will increase by 35 percent in the mitigation area by restoring the hydrology on 175 acres of the mitigation area and removal of grazing.

\section{Expected Results:}

The management actions will result in a gain of 39 yellow warbler habitat units on the mitigation area, which will fully replace the 14 habitat units lost in the reservoir basin, with a surplus of 25 habitat units. 

WETLAND HABITAT IMPACT \#3: Loss of 193 habltat units assoclated with wetland wildlife specles represented by the elk model.

\section{Assoclated Management Actlons:}

Wetland habitat management actions \#1, 2, 3, and 6

\section{Approach:}

The existing $\mathrm{HSI}$ for the entire study area of 0.222 is projected to reach 0.87 through implementation of the management actions.

Projected changes in habitat parameters associated with management actions include the following:

1. Deciduous shrub cover less than 2 meters in height will increase from the existing 7 percent to approximately 30 percent within the willow riparian and cottonwood/willow riparian habitat types through interplanting 32 acres of willow within the willow riparian vegetation type, restoring the hydrology, and removal of grazing.

2. Herbaceous cover within the wet meadow, willow riparian, and cottonwood/willow riparian types will increase to at least 90 percent through removal of grazing and restoring hydrology.

3. Willow cover in the wet meadow vegetation type will increase from less than 1 percent, which exists on the area, to approximately 15 percent through removal of grazing and restoring the hydrology. Since this natural revegetation will be a relatively slow process, low-density willow plantings on 5 acres of wet meadow will be done to reduce the lag time between impacts and mitigation as well as stabilize the streambank.

\section{Expected Results:}

The management actions will result in a gain of 208 elk habitat units on the mitigation area, which will fully replace the 193 habitat units lost in the reservoir basin, with a surplus of 15 habitat units.

WETLAND HABITAT IMPACT \#4: Loss of wildlife habitat assoclated with 8 acres of pond habltat and 3 acres of cottonwood habitat.

\section{Associated Management Actions:}

Wetland habitat management actions \#2, 4, 5, and 6.

\section{Approach:}

A minimum of 8 surface acres of pond habitat will be created in intermittent and dry oxbows through restoration and augmentation of hydrology. In addition, 7 acres of cottonwood will be planted.

\section{Expected Results:}

The 8 acres of ponds and 3 acres of cottonwood lost in the reservoir basin will be replaced acrefor-acre with a surplus of 4 acres of cottonwood habitat. 


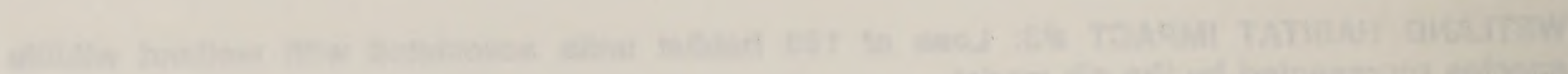

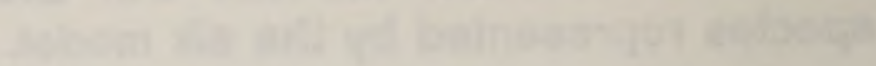

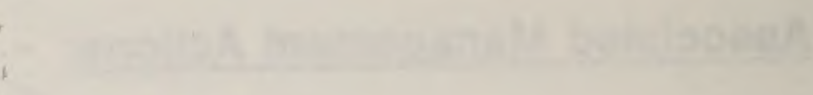

79.

41597094

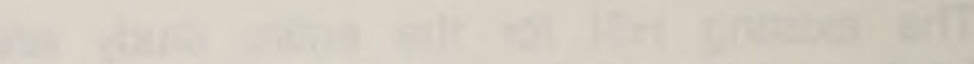

ran

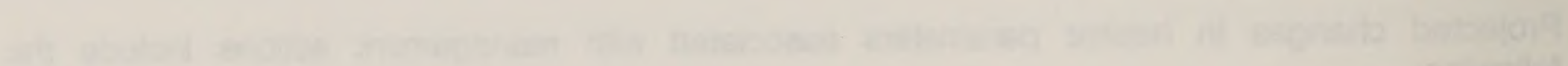

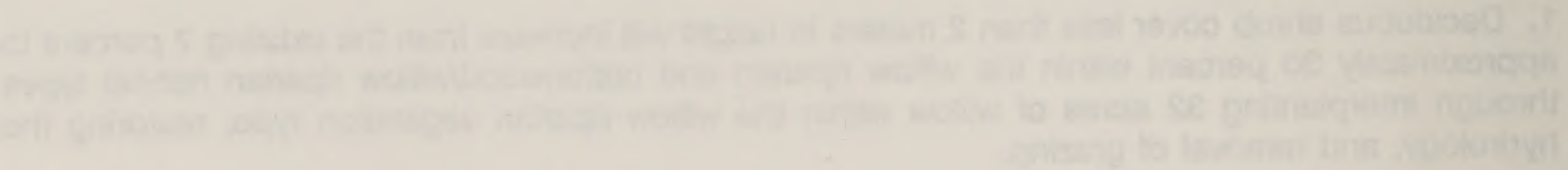

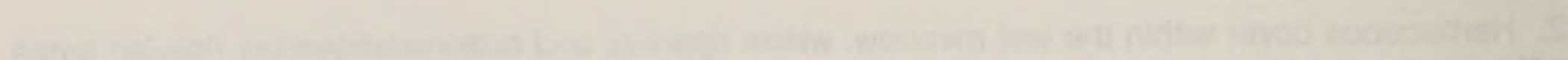
(1)

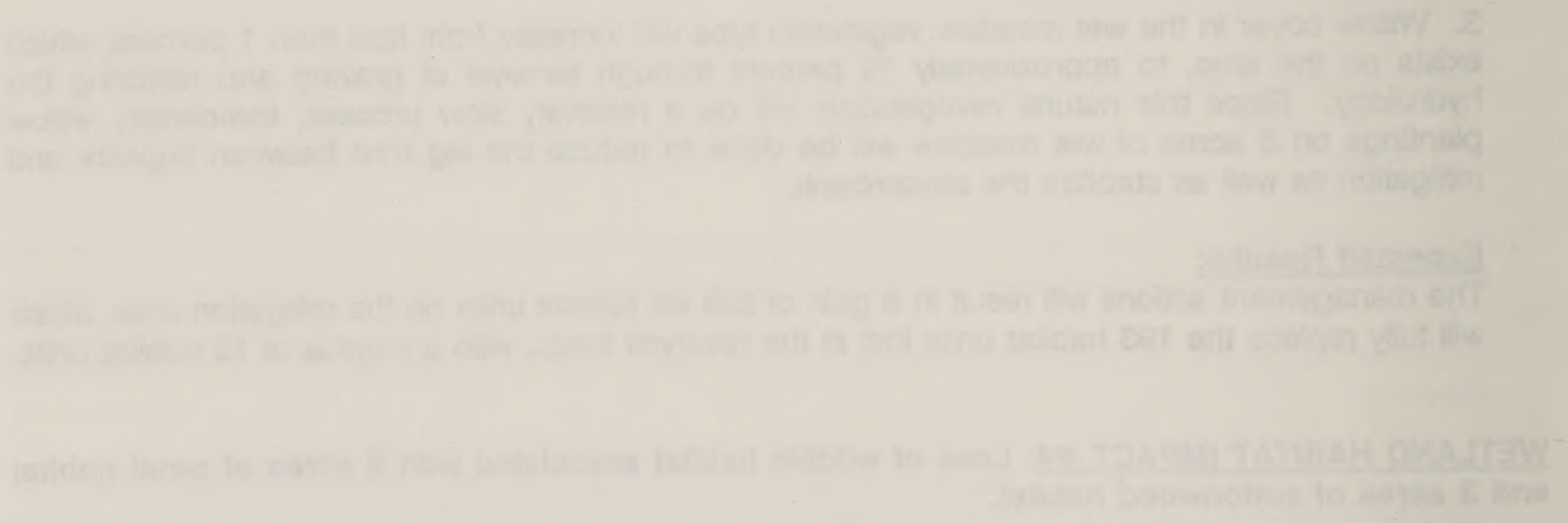

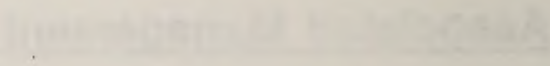

and

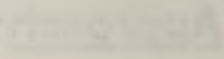

(1)

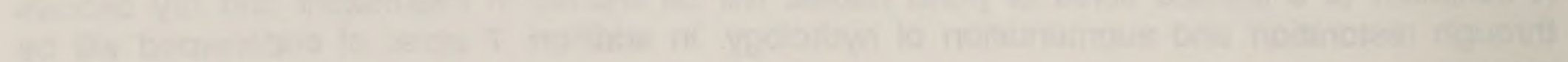

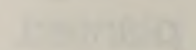

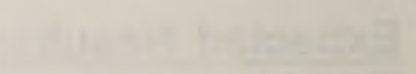


WETLAND HABITAT IMPACT \#5: Loss of 186 habitat units associated with the GWH model on 825 acres of wet meadow within the project area.

\section{Associated Management Actions:}

Wetland habitat management actions \#1,2, and 6.

\section{Approach:}

The existing HSI for the GWH model on the entire study area is 0.225 and is expected to increase to 1.0 through implementation of the management actions.

Projected changes in habitat parameters associated with management actions include the following:

1. Herbaceous cover will increase from the existing level of 45 percent to at least 90 percent through removal of grazing and restoration of hydrology.

2. Average herbaceous height will increase from the existing level of $13 \mathrm{~cm}$ to at least $60 \mathrm{~cm}$ through removal of grazing and restoration of hydrology.

\section{Expected Results:}

The management actions will result in a gain of $163 \mathrm{GWH}$ habitat units on the mitigation area, which will not fully replace the 186 habitat units lost in the reservoir basin, requiring at least 43 more acres of similar mitigation area to be located around the reservoir basin or adjacent to the mitigation area.

\section{SUMMARY}

The management actions discussed above would replace all the wetland wildlife values for beaver, yellow warbler, and elk models lost due to construction and operation of the proposed Muddy Creek Reservoir, and would provide a surplus of habitat units for all three species. The lower Muddy Creek mitigation area would not replace all of the habitat units for the GWH model, falling 23 units short. Therefore, at least another 43 acres of mitigation area in the Muddy Creek area needs to be added to the mitigation plan to achieve complete and total mitigation of all wildlife wetland values.

\section{BIG GAME}

\section{SUMMARY OF POTENTIAL IMPACTS AND METHODS}

Assessment of impacts to big game wintering areas in the project area were based on the acreage of winter habitat, designated by the CDOW (Olsen 1987), that will be inundated by the project. Selection of sites for use in mitigation of potential impacts to winter range were based on recommendations by the CDOW and BLM.

Approximately 1,523 acres of big game winter range will be inundated or destroyed by the proposed reservoir. Acreage and classification of various categories of winter range that could be impacted are presented in Table 7. Loss of winter range will have a significant effect on elk and mule deer populations by increasing intra- and interspecific competition for forage, decreasing the quality of 
forage, changing the daily movement of individuals, and by causing loss of microhabitat that provides shelter during severe weather. These factors may result in increased winter mortality due to starvation, physiological stress, highway mortality and ice-related mortality. Increased stress and nutritional deficiencies may also result in a subsequent loss of recruitment to populations.

Table 7. Acreage of big game winter range impacted due to inundation and facilities construction.

\begin{tabular}{lrrr}
\hline Species & $\begin{array}{r}\text { Winter } \\
\text { Range }\end{array}$ & $\begin{array}{r}\text { Winter } \\
\text { Concentration } \\
\text { Area }\end{array}$ & $\begin{array}{r}\text { Severe } \\
\text { Winter } \\
\text { Range }\end{array}$ \\
\hline Elk & 1,523 & 1,277 & 1,073 \\
Mule Deer & 1,519 & 673 & 289 \\
\hline
\end{tabular}

The proposed reservoir will also pose a physical barrier to both daily and seasonal migratory movements of big game. Thus, an increased number of big game animals will remain on the west side of the reservoir with an expected increase in daily movements across Highway 40. An increase in vehicle/big game collisions is likely, resulting in additional mortality of big game. Increased depredation of haystacks on the west and north sides of the proposed reservoir is likely if animals cannot travel to the east side of the reservoir. Additionally, attempts to cross the proposed reservoir on top of ice during the winter could result in death by drowning, predation, or injury and are considered an additional mortality factor.

\section{BIG GAME MITIGATION AREAS}

\section{Wolford and Little Wolford Mitigation Areas}

Two areas administered by the BLM, one on Wolford and another on Little Wolford Mountain, were selected through consultation with the CDOW and BLM as having potential for big game winter range enhancement (Figure 1). Approximately 400 acres within each of these two general areas will serve as mitigation sites for big game. These areas, which lie directly to the east of the proposed Muddy Creek Reservoir, are composed primarily of sagebrush steppe vegetation and lie within areas designated by the CDOW as big game winter range.

\section{Right-of-Way aiong U.S. Highway 40}

The proposed mitigation area in the right-of-way along U.S. Highway 40 adjacent to the project area will involve enough space to erect signs alerting both northbound and southbound motorists to the potential hazard of vehicle/big game collisions.

\section{BIG GAME MANAGEMENT ACTIONS}

Seven management actions will be required to mitigate impacts to big game winter range within the project area. These big game management actions, including details on implementation and cost are presented in the next section. This is followed by a section that presents each impact, identifies applicable management actions, and the expected results of implementation of the management actions. 


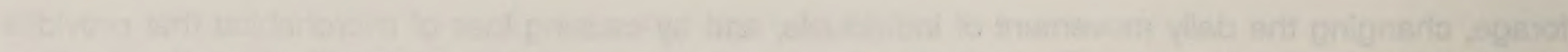

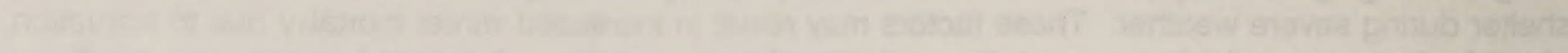

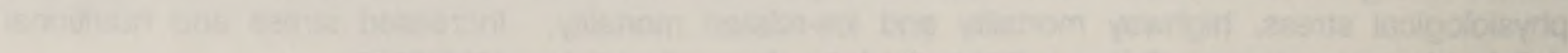

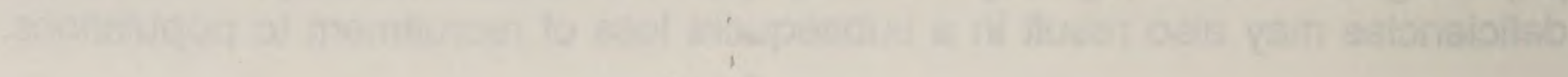

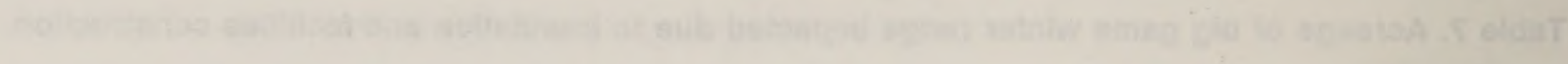

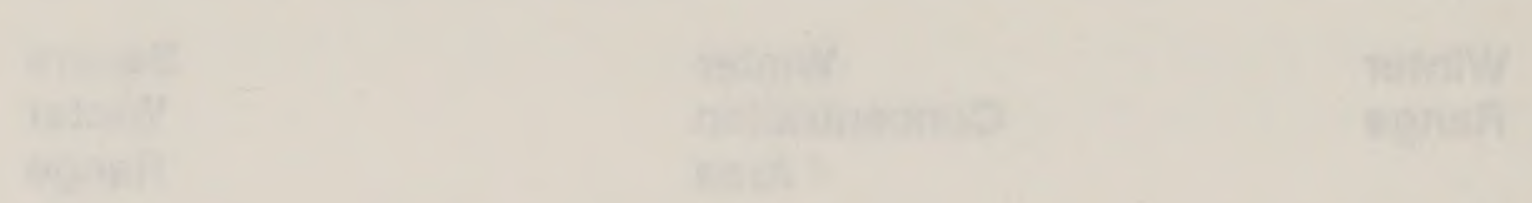
$=15090$ 20 


\section{Big Game Management Action \#1}

Conduct selective range improvement using fertilization and vegetation manipulation on approximately 400 acres in the vicinity of Wolford Mountain with potential for range improvement.

Responsibie Agency: BLM

Cooperating Parties/Agencies: CDOW

Areas identified for potential improvement are presented in Figure 1. Within these areas or those closely adjacent, specific sites will be selected that have high potential for successful range improvements. The specific 400 acres targeted for treatment will be selected by the BLM in cooperation with the CDOW. These areas will then be fertilized and undergo vegetative manipulation, if appropriate, in order to increase forage productivity. Prescribed treatments of big game winter range will follow specifications set by the BLM in order to achieve desired mitigation results and will be consistent with current land use practices. Deferment of grazing on treated acreage for a period of two years may be required in order to achieve desired results for big game. This could be accomplished by the placement of temporary electric fences around treated areas, allowing the remainder of the allotment to be used normally. However, due to the remote locations of areas targeted for improvements which will preclude heavy livestock utilization and/or flexibility in land use following certain treatments, such as fertilization only, deferment of grazing may not be necessary. Treatments requiring deferment of grazing will require consultation and cooperation between the CDOW and BLM.

In order to maintain the beneficial effects of fertilization and manipulation, fertilizer may need to be reapplied every 7 years and vegetation manipulation every 25 years at costs of $\$ 20,000$ and $\$ 28,000$, respectively. These costs are considered long-term maintenance. The actual need for retreatment will be determined by monitoring of the sites by CDOW and BLM as noted in big game management action \#4.

Estimated costs include the following:

- Fertilization of 400 acres @ \$50/acre:

$\$ 20,000$

- Vegetation manipulation of 400 acres @ \$70/acre:

$\$ 28,000$

- Long-term maintenance

$\$ 196,000$

- Total estimated cost:

$\$ 244,000$

\section{Big Game Management Action \#2}

Conduct selective range improvement using fertilization on 400 acres in the vicinity of Little Wolford Mountain, with potential for range improvement.

\section{Responsible Agency: BLM \\ Cooperating Parties/Agencies: CDOW}

Areas identified for potential improvement are presented in Figure 1. Treatment descriptions are the same as described for big game management action \#1 with the exception that this area will receive fertilizer treatment only.

In order to maintain the beneficial effects of fertilization and manipulation, fertilizer may need to be reapplied every 7 years at a cost of $\$ 20,000$ per application. This cost is considered long-term maintenance. The actual need for retreatment will be determined by monitoring of the sites by CDOW and BLM as noted in big game management action \#4. 
atana

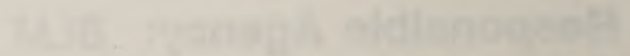

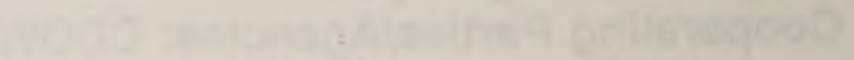

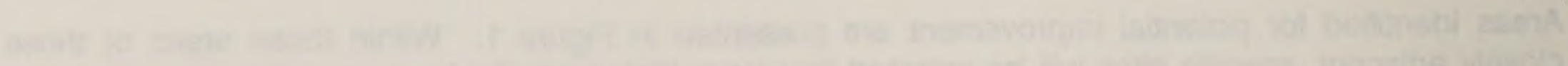
-

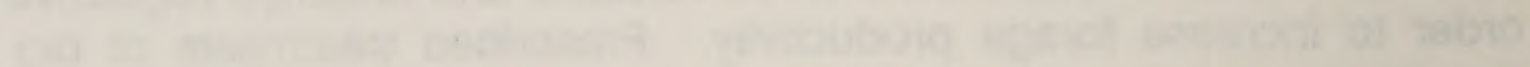

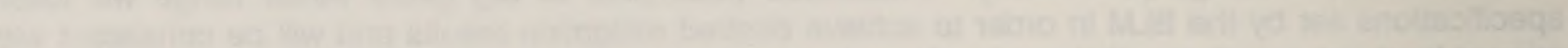
ran (5) Chatent

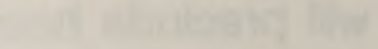

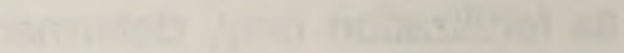

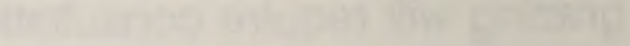

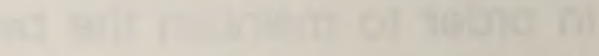

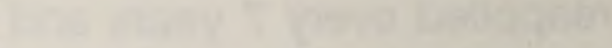
witas 
Estimated costs include the following:

- Fertilization of 400 acres @ \$50 /acre:

- Long-term maintenance:

- Total estimated cost:

$\$ 160,000$

\section{Big Game Management Action \#3}

Conduct selective range improvement using fertilization and vegetative manipulation on 125 to 175 acres with potential for range improvement, east of Muddy Creek, adjacent to the lower Muddy Creek mitigation area.

\section{Responsible Agency: BLM Cooperating Parties/Agencies: CDOW}

Areas preliminarily identified for potential improvement were presented in Figure 1. Within these or closely adjacent areas, specific sites will be selected that have high potential for successful range improvements. These areas will then be treated with fertilizer and/or undergo vegetative manipulation in order to increase forage productivity.

- Total estimated cost (treat 150 acres @ \$60/acre): \$9,000

\section{Big Game Management Action \#4}

Develop plans for monitoring and continued management of improved ranges, including approximate time tables of repeat treatments and associated costs if needed.

Responsible Agency: BLM

Cooperating Parties/Agencies: CDOW

Plans for monitoring big game range improvement efforts and continued management of improved ranges will be administered by the CDOW in cooperation with the BLM. Although repeated treatments are generally prescribed at 7-year intervals for fertilization and 25-year intervals for vegetative manipulation, specific timing and location for future treatments depend on circumstances that cannot be effectively predicted. The purpose of this management action is to assure that the treatments are done under the correct conditions and with input from CDOW and BLM.

\section{Big Game Management Action \#5}

Place unprotected haystacks at the north end of the proposed reservoir to act as an attractant to keep animals away from U.S. Highway 40 and ice hazards associated with the reservoir.

Responsible Agency: BLM

Cooperating Parties/Agencies: CDOW

Several unprotected haystacks will be placed near the areas designated for improvement in big game management action \#1. This will be repeated for 2 years to habituate big game animals to newly revitalized food sources. Location, size, and number of unprotected haystacks will be determined following consultation between the BLM and CDOW. 


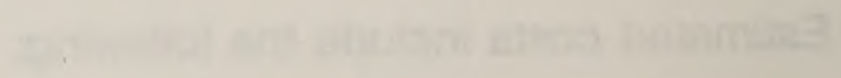

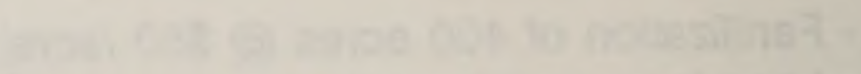

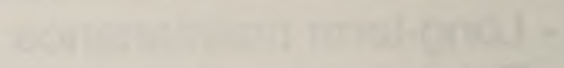

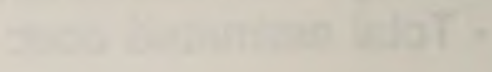

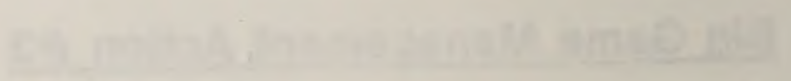

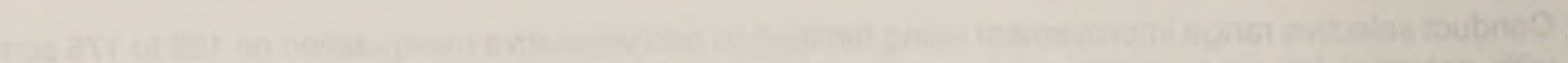

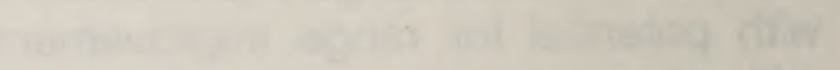

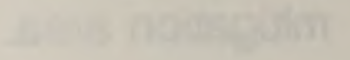

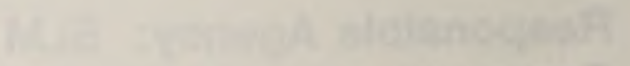

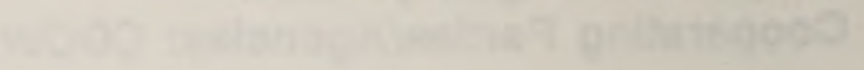

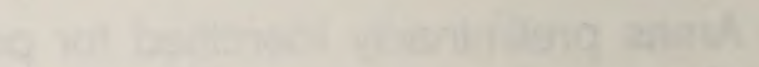

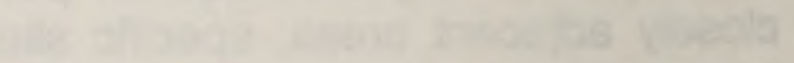

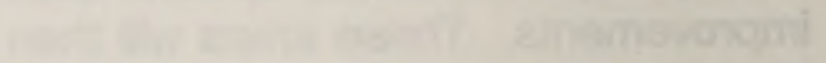

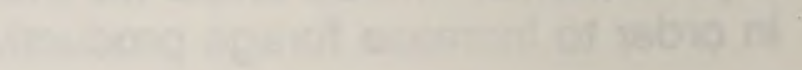

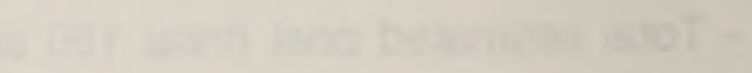

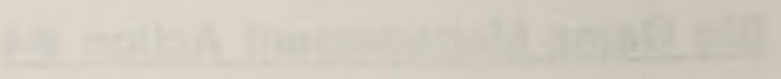

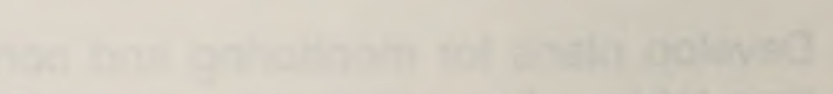

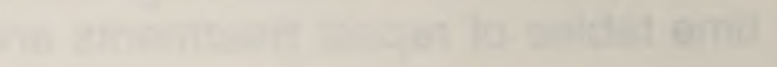

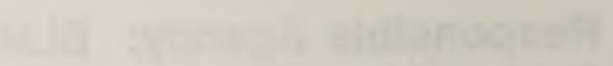

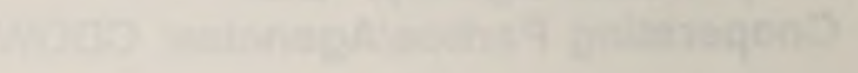

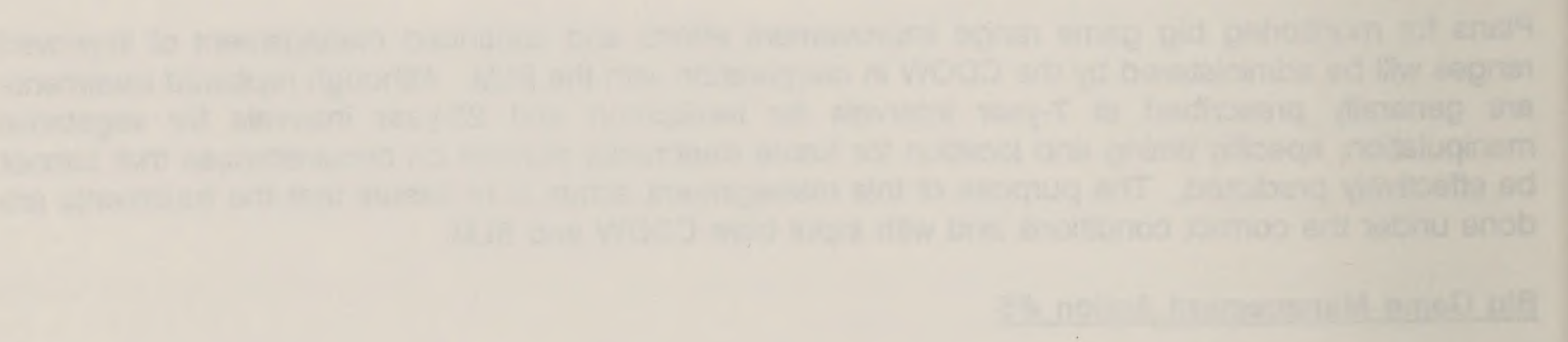

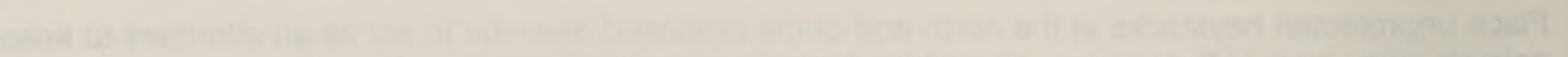
(1) 
Estimated costs include the following:

- $\$ 20,000 /$ year for two years: $\$ 40,000$

- Total estimated cost: $\$ \$ 40,000$

\section{Big Game Management Action \#6}

Erect signs along U.S. Highway 40 adjacent to the project area to alert motorists to the extreme danger of big game-automobile collisions.

Responsible Agency: BLM

Cooperating Parties/Agencies: CDOW and CDOT

A total of six signs will be erected in the right-of-way adjacent to U.S. Highway 40. Southbound signs will be located in the proximity of Pinto and Pass Creek. Northbound signs will be located approximately two miles north of Sheep Creek and in the proximity of Alkali Slough. Two other signs will be located at the discretion of the Colorado Highway Department in consultation with the CDOW and Colorado Highway Patrol. At least one sign in each direction will be either placed near existing lighting or have its own lighting during the winter months. The signs will inform motorists of the danger of big game crossing U.S. Highway 40 in the project area.

Estimated costs include the following:

- Two signs @ \$5,000 each: \$10,000

- Four signs @ \$1,000 each: \$4,000

- Total estimated cost: $\quad \$ 14,000$

\section{Big Game Management Action \#7}

Construct stack guards for haystacks located on private land at the north end of the proposed reservoir.

Responsibie Agency: BLM

Cooperating Parties/Agencies: CDOW and perhaps local ranchers

Stack guards for privately owned haystacks will be constructed around approximately six to eight haystacks at the north end of the proposed reservoir. The locations of these stack guards and construction specifications will be based on recommendations by the CDOW.

Estimated costs include the following:

- Eight stack guards @ \$1,000 each: \$8,000

- Total estimated cost: $\$ \$ 8,000$

BIG GAME IMPACTS AND ASSOCIATED MANAGEMENT ACTIONS

BIG GAME IMPACT \#1: Loss of winter forage associated with 1,523 acres of big game winter habitat. 


\section{Assoclated Management Actions:}

Big game management action \#1, 2, 3, and 4.

\section{Approach:}

1. Nutritional quality and palatability of forage on 925 to 975 acres will be increased on treated acreage, thereby increasing carrying capacity for big game.

2. High quality big game range will be available throughout the life of the proposed project.

3. Monitoring will provide information on the effectiveness of winter range improvements in meeting mitigation goals.

\section{Expected Results:}

The lost winter forage will be totally mitigated by the big game management actions in combination with the wetland habitat management action which will replace the lost winter forage by increasing forage amounts in other portions of the winter range.

BIG GAME IMPACT \#2: Mortality assoclated with blg game/vehlcie collisions and drowning or other factors related to lce hazards on the proposed reservolr.

\section{Assoclated Management Actions:}

Big game management actions \#5 and 6

\section{Approach:}

1. Mortality associated with big game-automobile collisions will be decreased.

2. Mortality associated with drowning or other factors related to ice hazards on the reservoir will be decreased.

3. Depredation on privately owned haystacks north of the reservoir will be decreased, thereby reducing animal control costs.

4. The public will be informed of a serious traffic hazard.

5. Possibility of injury or death and property damage to motorists using U.S. Highway 40 adjacent to the project area will be reduced.

\section{Expected Results:}

The proposed management actions will mitigate the impacts to the big game populations by maintaining present population levels with the reservoir in place.

BIG GAME IMPACT \#3: Property damage associated with big game depredation on privately owned haystacks north of the proposed reservoir. 
Associated Management Actions:

Big game management action \#7

\section{Approach:}

1. Depredation on privately owned haystacks north of the reservoir will be decreased by the additional stack guards, thereby reducing animal control costs.

\section{Expected Results:}

Depredation of haystacks will not increase with the proposed reservoir in place, totally mitigating this potential impact.

\section{OSTERHOUT'S MILKVETCH}

\section{SUMMARY OF POTENTIAL IMPACTS AND METHODOLOGY}

Potential impacts to Osterhout's milkvetch were based on surveys for sensitive plant species conducted during the summers of 1985, 1986, and 1987 (Grah and Neese 1986) (USDA/USDI 1988).

Approximately 18 acres of Osterhout's milkvetch habitat will be inundated by the proposed Muddy Creek Resenvoir. Of this, approximately 5 acres of good habitat, supporting approximately 800 to 900 individual plants and 13 acres of marginal habitat, supporting approximately 650 to 700 plants will be lost. During low frequency large flood periods when the resenoir will rise 8 to 10 feet (i.e., probable maximum flood), additional plants will be inundated. This low-frequency short-term inundation at flood stage will not significantly impact the species except at the shoreline where wave action could erode soil and dislodge plants.

In addition to loss of habitat and individuals due to inundation, the species could be impacted by perennial soil saturation in response to a rise in the water table induced by the filling of the reservoir. The magnitude and extent of such a projected impact is expected to be relatively small due to the occurrence and configuration of the water table around the reservoir margin. A small population of the species will also be directly impacted by the proposed transmission line tower relocation on the east side of Muddy Creek. Additionally, the proposed access road to the dam will cross populations mapped by the Colorado Natural Areas Program. These populations were not relocated in recent surveys (Grah and Neese 1986), but could be impacted if still in existence.

Indirect impacts to the species could include destruction of habitat and individuals due to recreation development and increased use of the area. This indirect impact is primarily associated with development and recreation on lands not under the administrative management of either the BLM or the District. The magnitude and extent of such impact cannot be determined at this time. Development of these lands will be under the dictates of county zoning ordinances. The District and the BLM will manage recreational activities along the shoreline and areas adjacent to the reservoir to preclude impact to the species. It is anticipated that the River District will contract with the Colorado Division of Parks and Outdoor Recreation to assume this responsibility. Management will include precluding vehicular access to areas containing the plant as well as providing developed recreation sites away from areas containing the plant. 
ana and

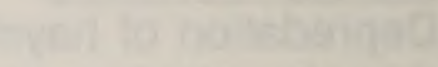

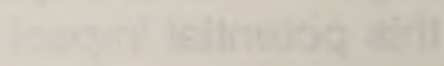




\section{OSTERHOUT'S MILKVETCH MITIGATION AREA}

\section{Designated Habitat for Osterhout's Milkvetch}

Proposed mitigation areas for Osterhout's milkvetch will include areas around the western perimeter of the proposed reservoir designated as habitat (Grah and Neese 1986). This area is primarily sagebrush uplands managed by the BLM. In addition, two off-site populations will be purchased and managed to mitigate the indirect impacts that could occur to the plant. These areas include a parcel of land in the Troublesome Creek drainage and a parcel of land along and just north of Colorado Highway 134 northwest of the highway's convergence with US Highway 40.

\section{OSTERHOUT'S MILKVETCH MANAGEMENT ACTIONS}

Four management actions will be required to mitigate impacts to Osterhout's milkvetch within the project area. These Osterhout's milkvetch management actions, including details on implementation and associated costs are presented in the next section. This is followed by a section that presents each impact, identifies management actions that apply to that impact, and presents the expected results of implementation of the management action.

\section{Osterhout's Milkvetch Management Action \#1}

To offset the potential indirect impacts that could occur to the plant, off-site compensation will be required. The District will contribute 50 percent of the funds needed to secure a parcel of land in the Troublesome Creek drainage which contains the species. This parcel is 52.5 acres and is located at the east $1 / 2$, southeast $1 / 4$, T2N, R79W, S30, except that portion lying west of Grand County Road 2. This parcel of land will be secured through the cooperative efforts of the District, the BLM, and the Nature Conservancy.

In addition, the District will purchase a parcel of land of at least 20 acres containing the plant west of the reservoir, subject to the approval of the BLM in consultation with the USFWS. The District will donate the land to BLM. Management will be designed and implemented in cooperation with the BLM, USFWS, and Colorado Natural Areas Program to favor the plants in terms of protection and perpetuation of the species.

\section{Responsible Agency: BLM and USFWS Cooperating Parties/Agencies: CNAP}

Since purchase price of off-site lands depends on final negotiations, the cost of this management action cannot be presented at this time.

\section{Osterhout's Milkvetch Management Action \#2}

The BLM will require the River District to manage the area containing the plant as part of the recreation plan. Management will include providing developed recreation sites away from areas containing the plant as well as precluding any activity that will impact the plant's habitat, such as vehicular access. As such, the District will erect fences along all access roads to the reservoir from US Highway 40 to preclude habitat destruction. The existing condition of the fence along US Highway 40 is sufficient to preclude access to the subject areas. Minor repair and maintenance of both existing and new fence may be required at a later point during the life of the project. This action will require approximately 3.0 miles of new fence at $\$ 4,500 /$ mile. 


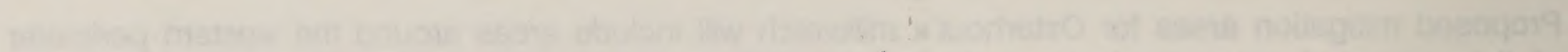

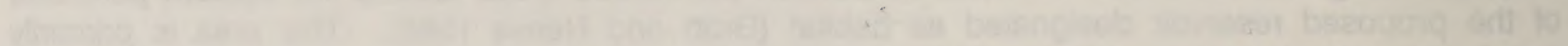

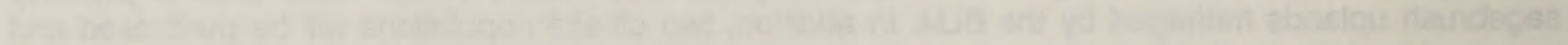

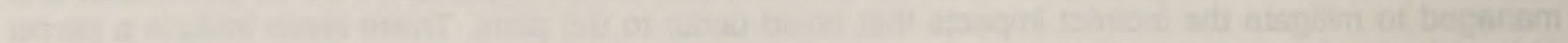

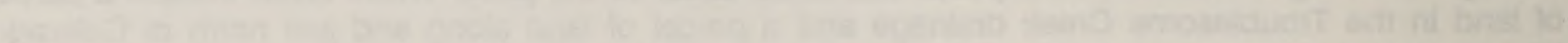

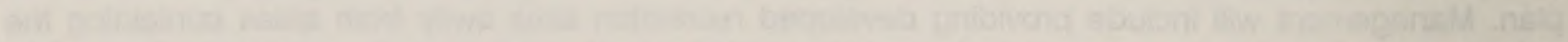

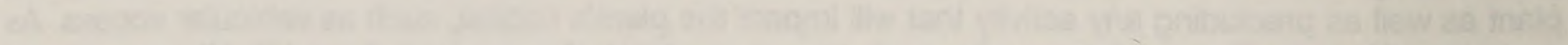

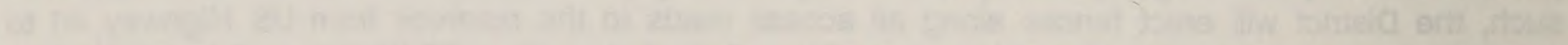
a

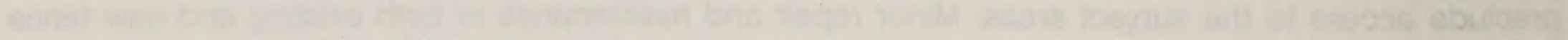

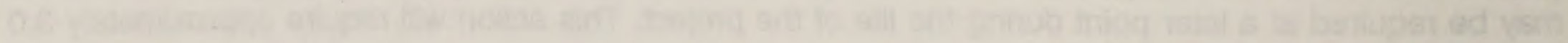

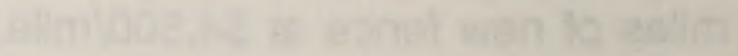


Responsible Agency: BLM

Cooperating Parties/Agencles: USFWS and CNAP

Estimated costs include the following:

- Fencing

$\$ 13,500$

- Fence Maintenance @ \$200/year for 50 years

$\$ 10,000$

- Total estimated cost

$\$ 23,500$

\section{Osterhout's Milkvetch Management Action \#3}

Have a qualified rare plant biologist inspect the flagged access road and other construction activities in the areas where the plant has been located in the past, and reroute these features where feasible if plants are found.

Responsible Agency: BLM

Cooperating Parties/Agencies: USFWS and CNAP

Estimated costs include the following:

- Principal Investigator 40 hours @ \$40/hr= \$1600

- Total estimated cost $\$ \$ 1600$

\section{Osterhout's Milkvetch Management Action \#4}

Clear sagebrush from several 0.25 to 0.5 acre plots adjacent to the existing population but not containing plants. Conduct experiments on the feasibility of transplanting or reseeding the plants into new areas. Collect information on the serial relationships of the plant and the effects of sagebrush dominance on the plants.

Responsible Agency: BLM

Cooperating Parties/Agencies: USFWS and CNAP

Estimated costs include the following:

- Principle investigator 160 hrs @ \$40/hr =

- Technician 160 hrs @ \$20/hr =

$\$ 3,200$

- Crawler tractor

$\$ 2,000$

- Total estimated cost

$\$ 11,600$

\section{OSTERHOUT'S MILKVETCH IMPACTS AND ASSOCIATED MANAGEMENT ACTIONS}

OSTERHOUT'S MILKVETCH IMPACT \#1: Direct losses of Indlviduals and habitat Incurred during construction and operation of the proposed project.

\section{Assoclated Management Actions:}

Osterhout's milkvetch management actions \#2 and 3 


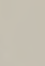




\section{Approach}

1. The feasibility of transplanting or seeding the plant into areas where it does not occur will be determined, possibly allowing for the salvage of individual plants that will be inundated by the proposed reservoir and increasing the area occupied by the plant.

2. It will be determined whether the plant is a pioneer or an early serial species. Its tolerance of habitat disturbance will be determined.

3. The effects of sagebrush dominance on the plant will be determined.

\section{Expected Results}

These actions would fully mitigate the direct impacts to the plant and its habitat caused by the reservoir construction and operation.

OSTERHOUT'S MILKVETCH IMPACT \#2: Indirect Impacts to the plant and its habitat incurred through recreational activities and private land development around the proposed reservoir.

\section{Assoclated Management Actlons:}

Osterhout's milkvetch management action \#1

\section{Approach:}

1. Minimization of impacts to the plant that could occur through recreational use around the edge of the reservoir, as well as in other areas within its range of distribution.

2. Minimization of impacts to the plant and its habitat on private land around the proposed reservoir.

\section{Expected Results:}

Indirect impacts to the plant and its habitat due to reservoir operation will be fully mitigated.

\section{ADDITIONAL ENHANCEMENT AND CONSERVATION MEASURES}

In addition to the mitigation measures discussed in the preceding portions of this report, the Muddy Creek Reservoir project will require additional measures related to mitigation efforts. These additional measures and associated costs are discussed below.

\section{COSTS FOR DEVELOPING THE MITIGATION PLAN}

Costs for developing the mitigation plan involved field work to describe the proposed mitigation area, development of draft plans, and meetings where the draft plans were discussed. Agencies involved in developing the mitigation plan include the BLM, Forest Service, CDOW, USFWS, EPA, and the Corps of Engineers. Nearly a year has been spent developing this plan. Costs for this effort are $\$ 50,000$. 



\section{RESERVOIR WATER QUALTY MONITORING}

The U.S. Geological Survey will monitor water quality in the reservoir so that if problems are identified, corrective action in the operation plan can be evaluated. The monitoring will be conducted at three sites (near inflow, mid-reservoir, and near dam) on the surface of the reservoir and at two sites (midreservoir and near dam) on the bottom of the reservoir. Sampling will be conducted three times each year (May, July, and September) and will include nutrients, major ions, selenium, chlorophyll $\underline{\text { a }}$ phytoplankton, and trace metals. Lake profiles of temperature, specific conductance, $\mathrm{pH}$, dissolved oxygen, and secchi disc readings will be done at all sites each visit. Initially, costs for this effort will be about $\$ 45,000$ annually, with a total cost $\$ 392,000$ over the life of the study.

\section{COSTS FOR RARE FISH STUDIES AS PART OF THE RECOVERY IMPLEMENTATION PROGRAM}

Potential impacts to the endangered fishes of the Colorado River were discussed in the Biological Assessment prepared for this project. It was assumed, and confirmed by the USFWS, that the River District will pay $\$ 10 / a c r e-f o o t ~ o f ~ d e p l e t i o n$ for water removed from the Colorado River as per the agreement in the Recovery Implementation Program. The estimated depletion for the Muddy Creek Reservoir project is 7,864 acre feet. This projects to a cost of $\$ 78,640$.

\section{COST FOR FISH STOCKING IN THE RESERVOIR}

The River District has agreed to provide the CDOW with funds for annual stocking of the reservoir. This cost has been estimated by CDOW at $\$ 10,000$ annually. For the 50-year life of the project, this could total $\$ 500,000$. It is possible that a self-sustaining fishery could be established in the reservoir, or that future stocking could be reduced. This would be decided by the River District and CDOW in the future. 



\section{SUMMARY OF MITIGATION AND ENHANCEMENT COSTS}

This section summarizes costs for mitigation and enhancement for the proposed Muddy Creek Reservoir project. Table 8 presents the costs associated with the mitigation plan. Table 9 presents the costs for the six major components of the mitigation and enhancement package. 



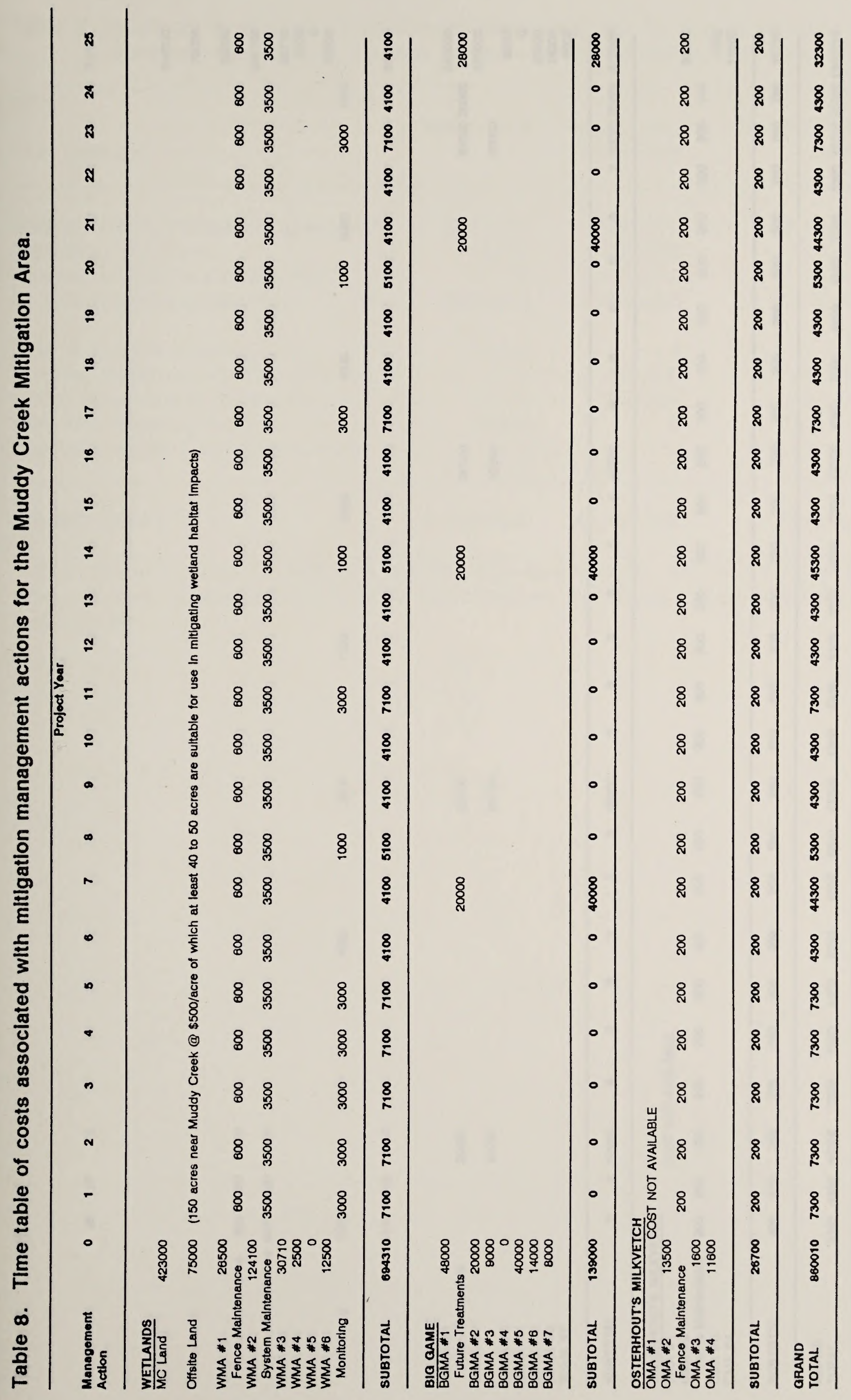




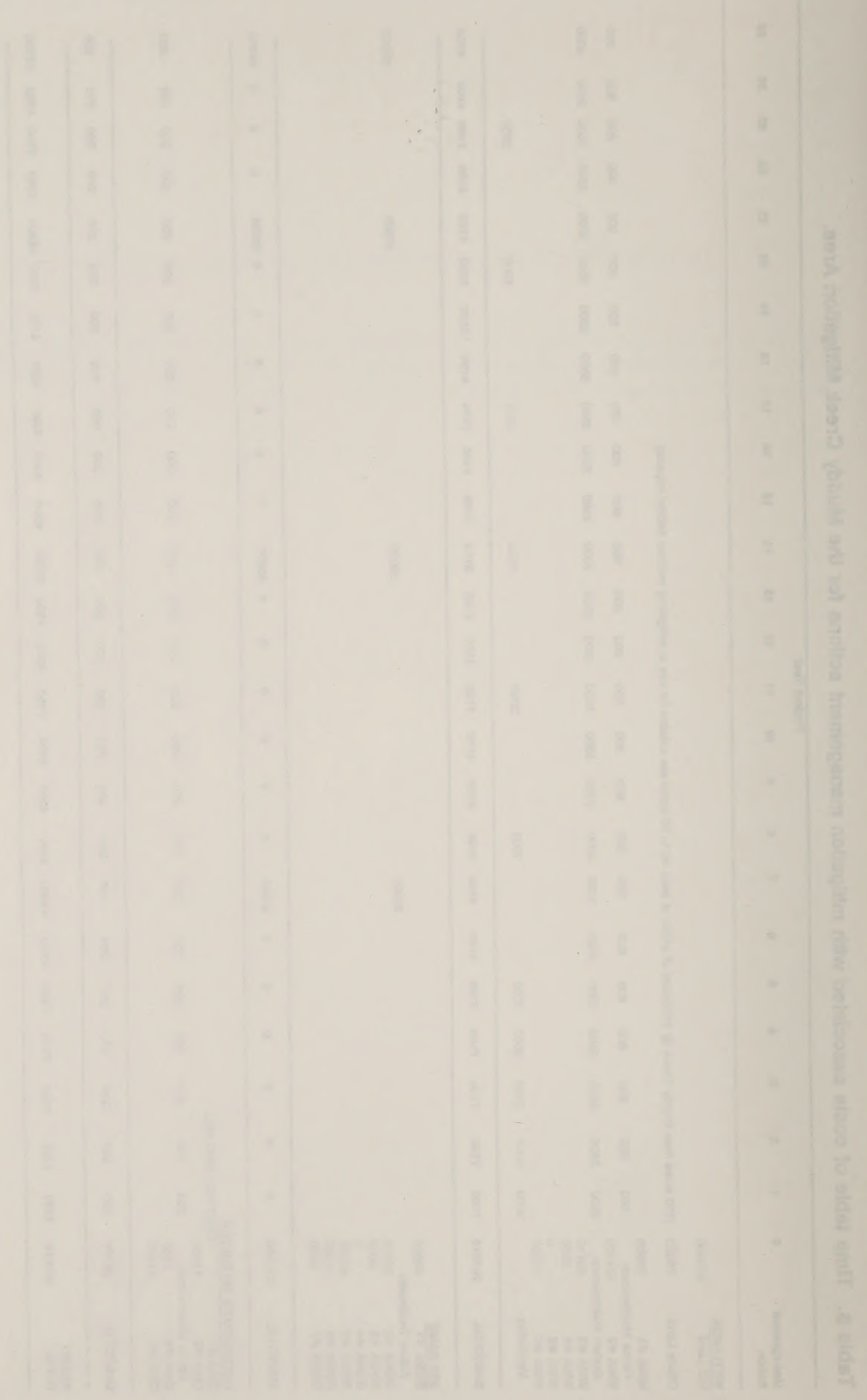




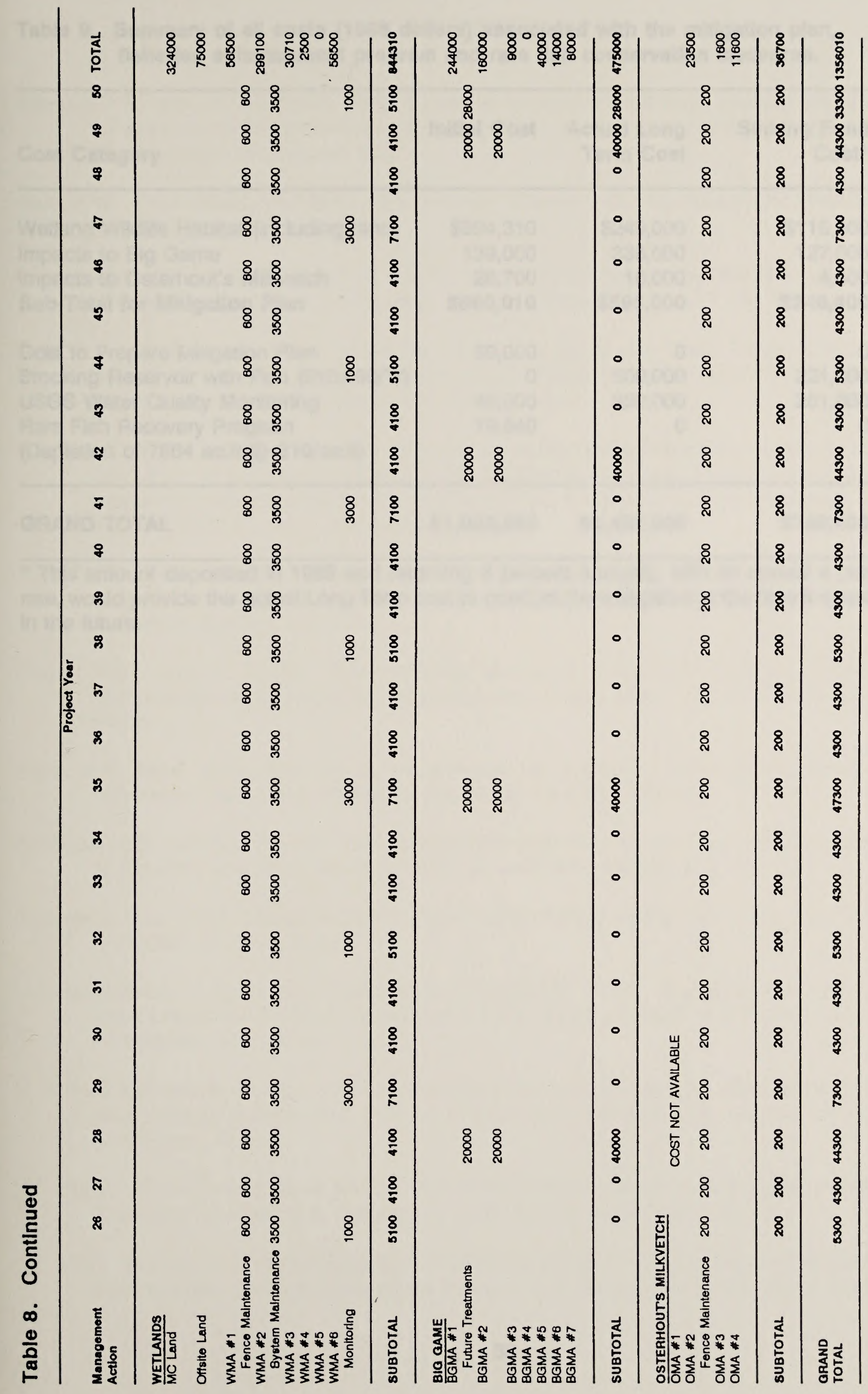



Table 9. Summary of all costs (1988 dollars) associated with the mitigation plan, fisherles enhancement program and rare fish conservation measures.

Cost Category

Initial Cost

Actual Long

Term Cost

Sinking Fund

Cost*

Wetland Wildlife Habitat (including land)

Impacts to Big Game

Impacts to Osterhout's Milkvetch

Sub-Total for Mitigation Pian

Cost to Prepare Mitigation Plan

Stocking Reservoir with Fish $(\$ 10,000 / \mathrm{Yr})$

USGS Water Quality Monitoring

Rare Fish Recovery Program

(Depletion of 7864 ac.ft @ \$10/ac.ft)

$\$ 694,310$
139,000
26,700
$\$ 860,010$

$\$ 249,000$

336,000

10,000

$\$ 115,000$

127,000

4,400

$\$ 595,000$

$\$ 246,400$

$\begin{array}{rrr}50,000 & 0 & 0 \\ 0 & 500,000 & 221,000 \\ 45,000 & 392,000 & 261,000 \\ 78,640 & 0 & 0\end{array}$

GRAND TOTAL

$\$ 1,033,650$

$\$ 1,487,000$

$\$ 728,400$

* This amount deposited in 1989 and returning 8 percent annually, with an annual 4 percent inflation rate, would provide the Actual Long Term cost to conduct the mitigation at the time it would be required in the future. 


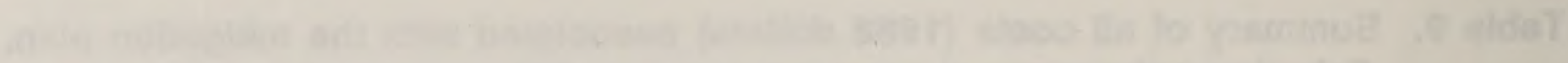

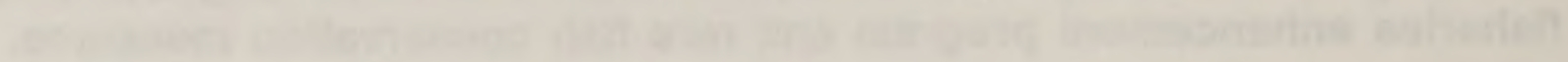

(14)

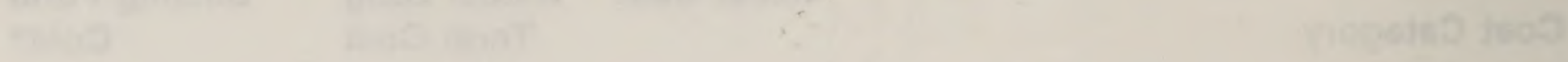
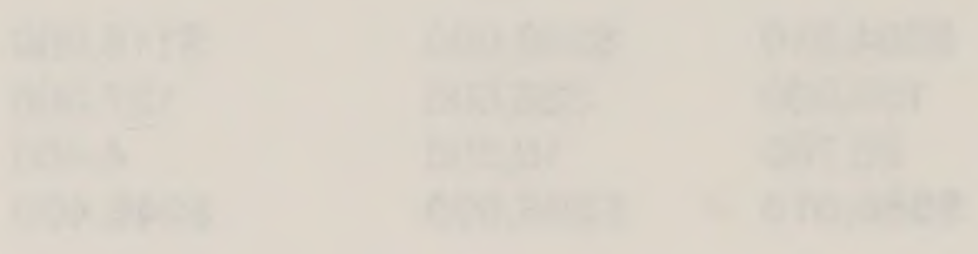

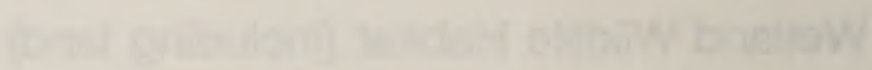

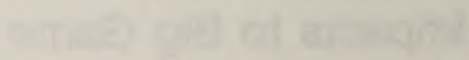

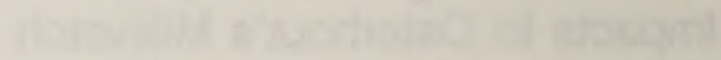

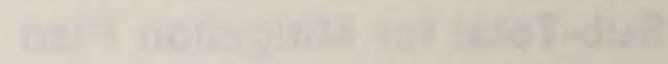

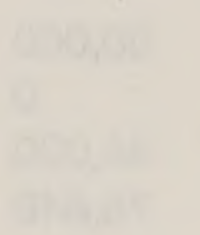

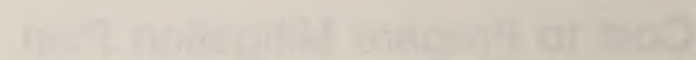

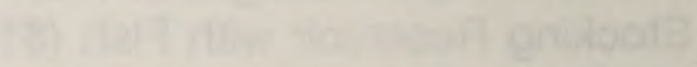

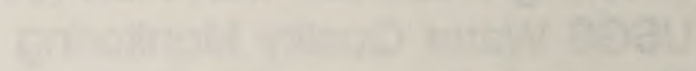

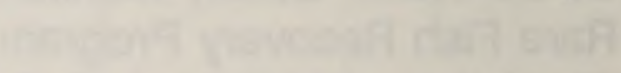
and 


\section{REFERENCES CITED}

Adamus, P.R. and L.T. Stockwell. 1983. A method for wetland functional assessment, Volumes 1 and 2. Report No. FHWA-IP-82-23 and FHWA-IP-82-24. U.S. Dept. of Transportation, Federal Highway Administration, Washington D.C.

Allen, A.W. 1983. Habitat suitability index models: Beaver. U.S. Fish Wildl. Serv. FWS/OBS-812/10.30 Revised. 20 pp.

Cooperrider, A.Y., R.J. Boyd, and H.R. Stuart, eds. 1986. Inventory and monitoring of wildlife habitat. U.S. Dept. Inter., Bur. Land Manage. Service Center. Denver, CO xviii. 858 pp.

Grah, O.J. and E. Neese. 1986. Rare Plant Survey of the Muddy Creek Reservoir Site. Vegetation Technical Report for the Rock Creek/Muddy Creek Reservoir submitted to BIOMEST, Inc., Logan, Utah. TR-114-8 (revised June 1987). 4 pp.

Hugie, R.D. and Masslich, W.J. 1987. A summary of the habitat evaluation procedure (HEP) studies conducted at proposed mitigation sites on Egeria and lower Muddy Creeks during 1987 in conjunction with the DEIS for the proposed Rock Creek/Muddy Creek Reservoir. Unpublished report, BIOMEST, Inc., Logan, Utah. 28 pp.

Olsen, P.O. 1987. Regional Manager, Colorado Division of Wildlife, Grand Junction, Colorado. Letter transmitted to Jerry Schmidt, Forest Supervisor, U.S. Forest Service, Routt National Forest, Steamboat Springs, Colorado.

Pekins, R.S. and R.D. Hugie. 1986. Habitat Evaluation Procedures Analysis Summary. Wildlife Technical Report submitted to BIOMEST, Inc., Logan, Utah. TR-114-7 (revised August 1987). $24 \mathrm{pp}$.

Petts, G.E. 1984. Impounded rivers, perspectives for ecological management. Wiley Interscience Publication. John Wiley and Suns, New York, New York, 326 pp.

Schrieber, J.D., and D.L. Rausch. 1979. Suspended sediment - phosphorus relationships for the inflow and outflow of a flood detention reservoir. Jour. Env. Quality: 8(4), 510-514.

Schroeder, R.L. 1982. Habitat suitability index models: yellow warbler. U.S. Dept. Int., Fish Wildl. Serv. FWS/OBS-82/10.27. 7 pp.

U.S. Department of Agriculture, Forest Service (USDA-FS). 1988. Supplemental Draft Environmental Impact Statement for Rock Creek/Muddy Creek Reservoir, Routt and Grand Counties, Colorado. FS/EPA No. 02-11-87-02.

U. S. Fish and Wildlife Service. 1980a. Ecological Services Manual (101 ESM) Habitat as a basis for environmental assessment. Division of Ecological Services, U.S. Department of the Interior. Washington, D.C.

- 1980b. Ecological Services Manual (102 ESM) Habitat evaluation procedures (HEP). Division of Ecological Services, U.S. Department of the Interior. Washington, D.C.

- 1981. Ecological Services Manual (103 ESM)-Standards for the development of habitat suitability index models. Division of Ecological Services, U.S. Department of the Interior. Washington D.C. 

APPENDIX A

MUDDY CREEK FISHERY ENHANCEMENT 



\section{MUDDY CREEK FISHERY ENHANCEMENT}

The construction of the Muddy Creek Dam would create a potential cold water trout fishery in Muddy Creek below the dam. Flows from the dam would be colder and clearer than present summer flows, and winter flows would be warmer than present conditions. It is expected that these conditions will be very conducive to a trout fishery. An IFIM analysis conducted on Muddy Creek for the DEIS indicated that the stream, as is, would have a fair amount of trout habitat. The following discussion points out potential enhancement measures that could be implemented to improve trout habitat in Muddy Creek.

The major problems with the habitat at Muddy Creek is a lack of cover and a wide, shallow channel with few pools. Both of these characteristics have been caused by a loss of streamside riparian vegetation that has allowed the streambanks to erode. This has tended to widen the channel, and few streamside trees or shrubs are present to provide overhead cover. The bank erosion from the tailwater area, as well as upstream erosion, has added many fines to the substrate, which reduces the ability of the substrate to supply benthic invertebrates (insects, etc.) for fish food. Therefore, to improve the stream for trout, the streambanks need to be stabilized, riparian vegetation needs to be reestablished and the channel needs to be deepened and narrowed in places. The mitigation plan includes measures to improve the riparian vegetation. Planting of willows and cottonwoods along the streambanks will aid in reducing bank sloughing and erosion, but many of the banks will also require additional bank stabilization.

Therefore, several enhancement features will be needed to bring Muddy Creek up to its potential for trout habitat. The somewhat clearer flows and decreased sediment input from upstream should aid in cleaning the streambed of fine materials. Most areas below dams become armored with cobble or larger rock as finer particles are moved downstream by the clearer water. Bank stabilization should be the first enhancement measure undertaken. Once most of the major actively eroding areas are stabilized, measures to create instream habitat, primarily creation of pools and cover, could begin. Bank stabilization, in concert with clearer, less sediment-laden flows, will tend to create a deeper, more defined channel.

Several methods have been used to stabilize banks. Rip-rap is often used but this method generally does not provide any real gain in fish habitat. Large rocks, used in conjunction with plantings of riparian trees and shrubs, will provide a more natural solution and better fish habitat. The Forest Service has used juniper trees to stabilize banks in some western streams. Trees are cut, and then fastened to the eroding streambank with their tops pointed down stream. The trees must be able to withstand the force of high flows, but their branches will reduce velocities such that sediment in the water will drop out along the bank. These areas are then planted with riparian grasses and shrubs for more permanent stabilization. Deflector logs have also been used. These are logs placed along the unstable bank to deflect the main force of the current. The area behind the log can be filled in and planted. A site-specific analysis of the stream will be needed to determine which stabilization method to use. Cost and availability of raw materials may also be important in determining which method to use.

Once banks have been stabilized and the riparian vegetation planted, additional enhancement of instream habitat could begin. This would involve creating pools, and providing instream cover. Again, several methods could be used, including placement of large boulders, creation of small dams with logs of rocks that will create areas of scour, and using short sections of logs to create pools along the shoreline. The planned channel control structure for the wetland habitat mitigation will provide fairty deep pools below it, as well as pooling of flows above it. It is quite possible the pool above the channel control structure will fill in with finer sediments, so angled logs or rocks along the shorelines of the ponded area would help create a deeper, narrow channel down the center of the stream, as well 


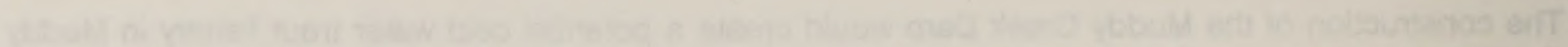

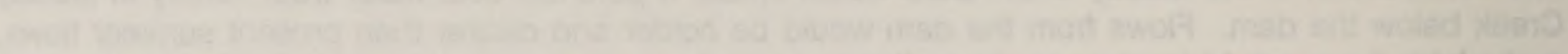

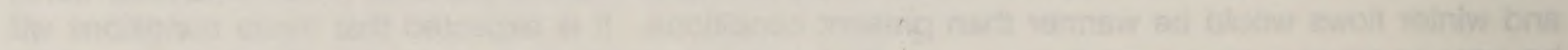

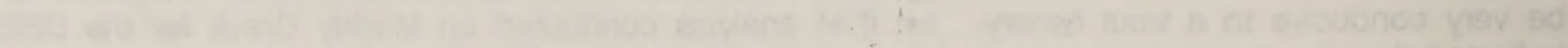

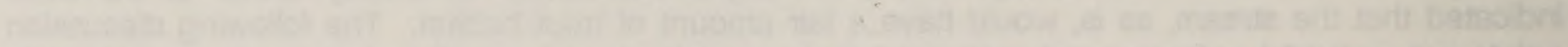

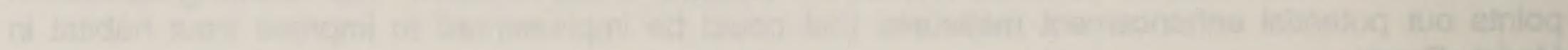

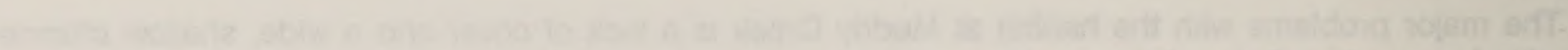

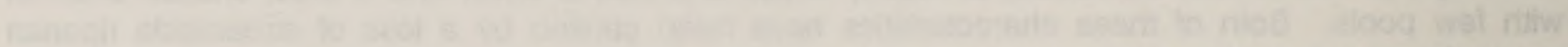

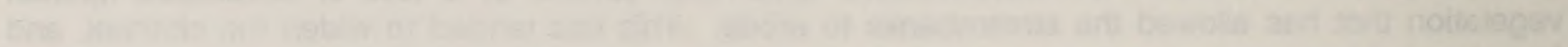

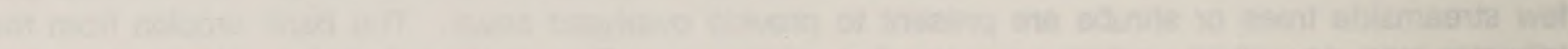
(1) ent

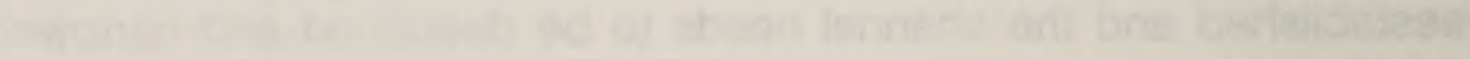

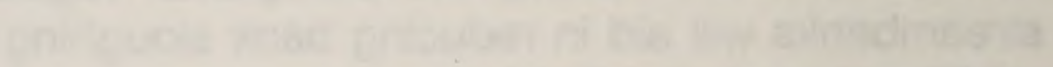

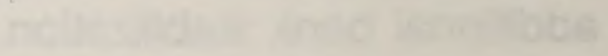

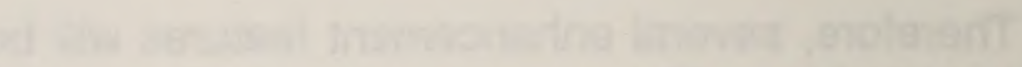

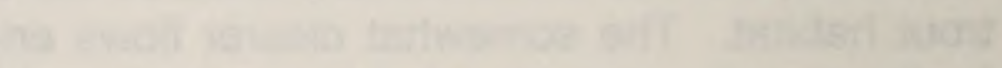

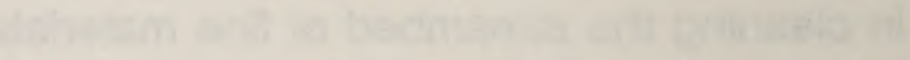

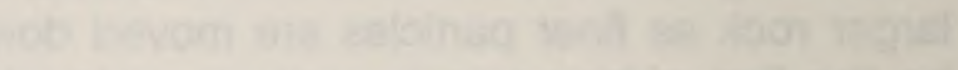

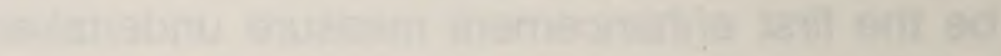

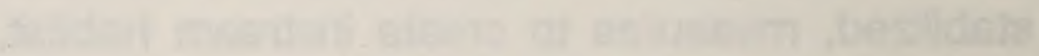

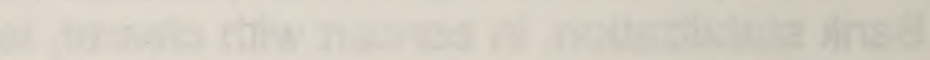


as more turbulence during high flows. This will aid in keeping the ponded area from becoming a shallow, silty area by creating enough cutting force to move some of the finer sediments downstream during high flows.

Enhancement of the Muddy Creek tailwater fish habitat could greatly improve the area as a recreational resource. Major improvements needed include bank stabilization, and creation of more pool habitat. Just the reduction in grazing and the planting of riparian vegetation planned for the wetland habitat mitigation will improve the fish habitat significantly. More directed efforts as suggested above have the potential to create an excellent trout stream out of the tailwater area. 

APPENDIX B

CALCULATION OF THE HEP MODELS 


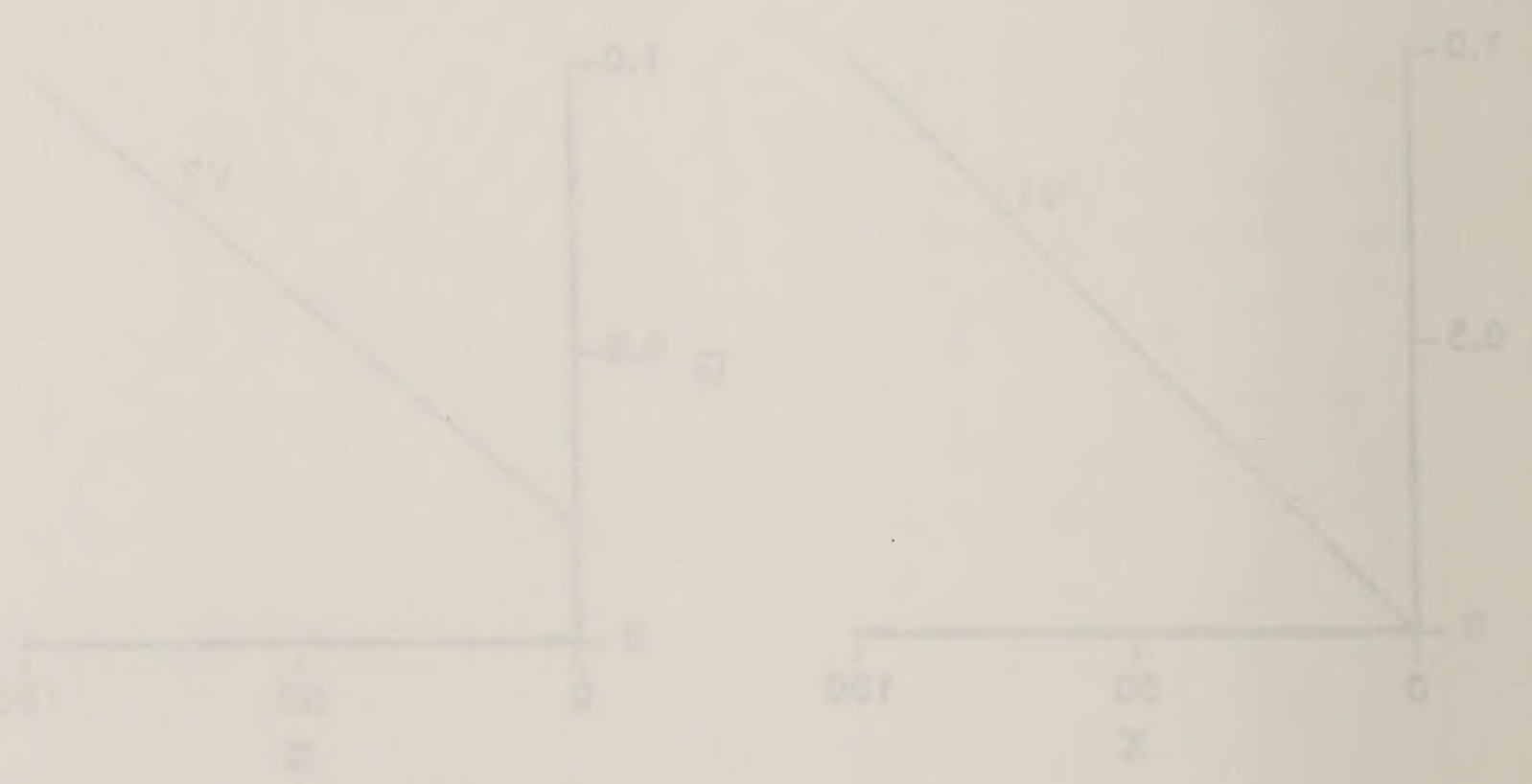


\section{SUITABILITY CURVES CONTINUED}
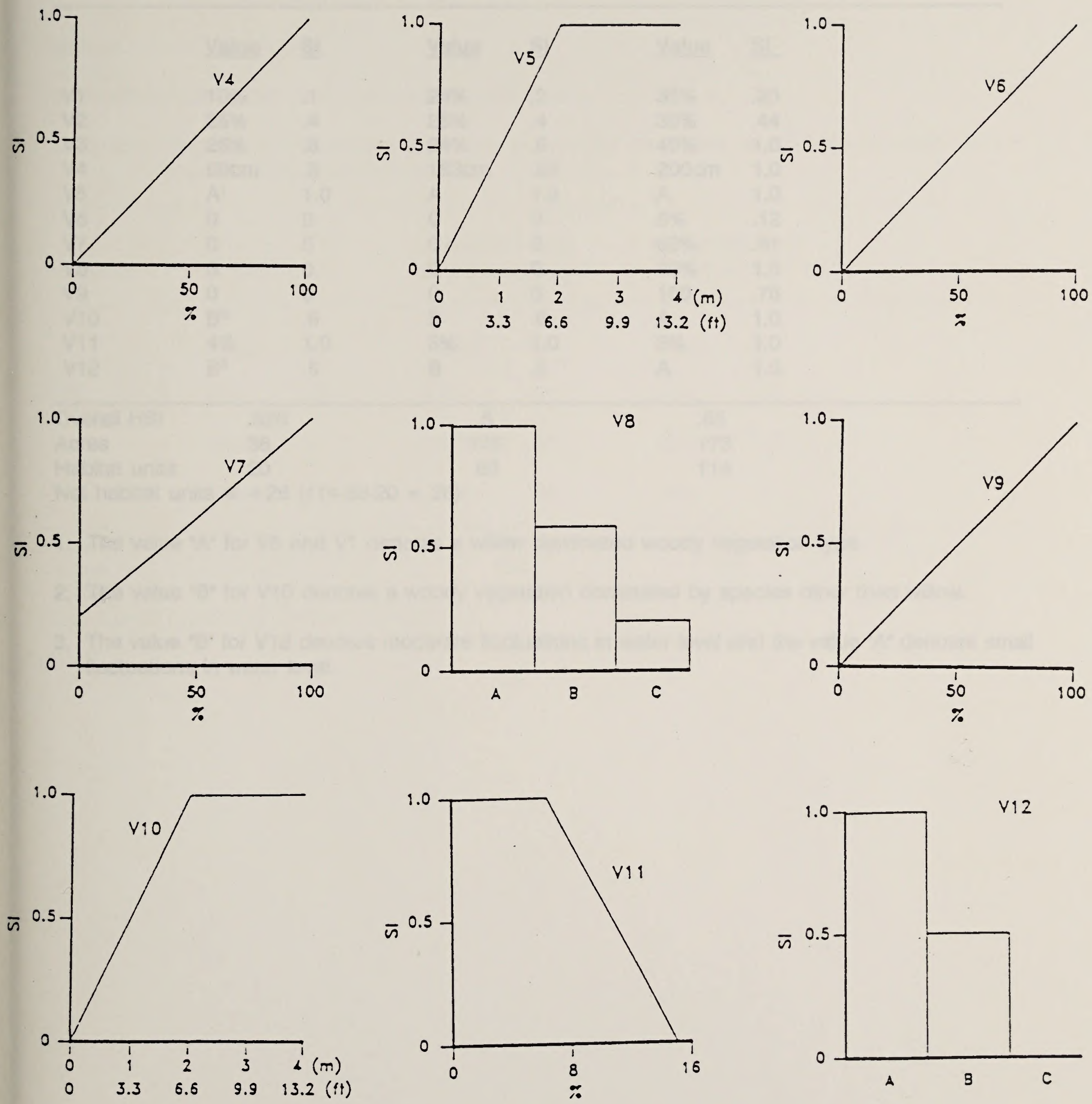

Table B-1. Parameter values and suitabllity Indlces for the beaver model used for the Muddy Creek Reservolr project.

\begin{tabular}{lllllll} 
Varlable & Project Area & & \multicolumn{2}{c}{$\begin{array}{l}\text { Mitigation area } \\
\text { Pre-management }\end{array}$} & $\begin{array}{l}\text { Mitigation area } \\
\text { Post-manage }\end{array}$ \\
& Value & $\underline{\text { SI }}$ & Value & $\underline{\text { SI }}$ & $\underline{\text { Value }}$ & $\underline{\text { SI }}$ \\
& V & & & & & \\
V1 & $10 \%$ & .1 & $24 \%$ & .2 & $35 \%$ & .25 \\
V2 & $25 \%$ & .4 & $25 \%$ & .4 & $30 \%$ & .44 \\
V3 & $26 \%$ & .6 & $24 \%$ & .6 & $40 \%$ & 1.0 \\
V4 & $59 \mathrm{~cm}$ & .3 & $183 \mathrm{~cm}$ & .93 & $200 \mathrm{~cm}$ & 1.0 \\
V5 & $\mathrm{A}^{1}$ & 1.0 & $\mathrm{~A}$ & 1.0 & $\mathrm{~A}$ & 1.0 \\
V6 & 0 & 0 & 0 & 0 & $5 \%$ & .12 \\
V7 & 0 & 0 & 0 & 0 & $50 \%$ & .61 \\
V8 & 0 & 0 & 0 & 0 & $40 \%$ & 1.0 \\
V9 & 0 & 0 & 0 & 0 & 150 & .76 \\
V10 & $\mathrm{B}^{2}$ & .6 & $\mathrm{~B}$ & .6 & $\mathrm{~A}$ & 1.0 \\
V11 & $4 \%$ & 1.0 & $3 \%$ & 1.0 & $3 \%$ & 1.0 \\
V12 & $\mathrm{B}^{3}$ & .5 & $\mathrm{~B}$ & .5 & $\mathrm{~A}$ & 1.0
\end{tabular}

\begin{tabular}{llcl}
\hline Overall HSI & .526 & .5 & .65 \\
Acres & 38 & 135 & 173 \\
Habitat units & 20 & 68 & 114
\end{tabular}

Net habitat units $=+26(114-68-20=26)$

1. The value " $A$ " for $V 5$ and $V 1$ denotes a willow dominated woody vegetation type.

2. The value 'B' for $V 10$ denotes a woody vegetation dominated by species other than willow.

3. The value ' $\mathrm{B}$ " for $\mathrm{V} 12$ denotes moderate fluctuations in water level and the value " $\mathrm{A}$ ' denotes small fluctuations in water level. 

HEP EVALUATION SPECIES: Yellow warbler

VARIABLE DESCRIPTION:

V1 = Percent deciduous shrub crown cover

V2 = Average height of deciduous shrub canopy

V $3=$ Percent deciduous shrub canopy comprised of hydrophytic shrubs

MODEL: $(\mathrm{V} 1 \times \mathrm{V} 2 \times \mathrm{V} 3)^{1 / 2}$

SUITABILITY CURVES: Published in Schroeder (1982).

Table B-2. Parameter values and suitabllity Indices for the Yellow warbler model used for the Muddy Creek Reservolr project.

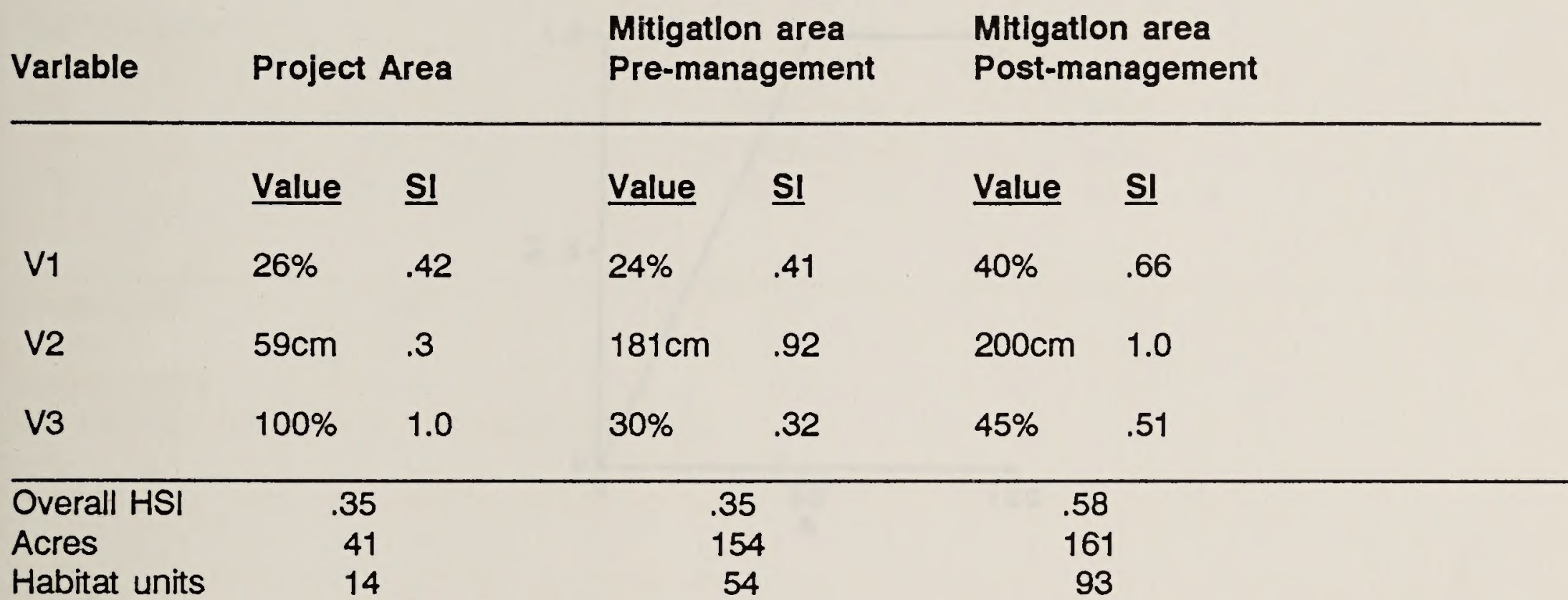

Net habitat units $+25 \quad(93-54-14=25)$ 



\section{HEP EVALUATION SPECIES: EIK}

\section{VARIABLE DESCRIPTION:}

$$
\begin{aligned}
& \text { V1 }=\text { Percent herbaceous cover } \\
& \text { V2 }=\text { Percent of herbaceous cover that is graminoid } \\
& \text { V } 3 \text { = Percent cover of shrubs less than } 2 \text { meters in height }
\end{aligned}
$$

MODEL: [(V1 $\times$ V2) $)^{1 / 2} \times \mathrm{V} 3$ ) $]^{1 / 2}$ for each habitat type. Overall HSI is calculated by weighing the HSI for each habitat type by the percentage of area that it occupies and summing all the habitat types.

\section{SUITABILITY CURVES:}
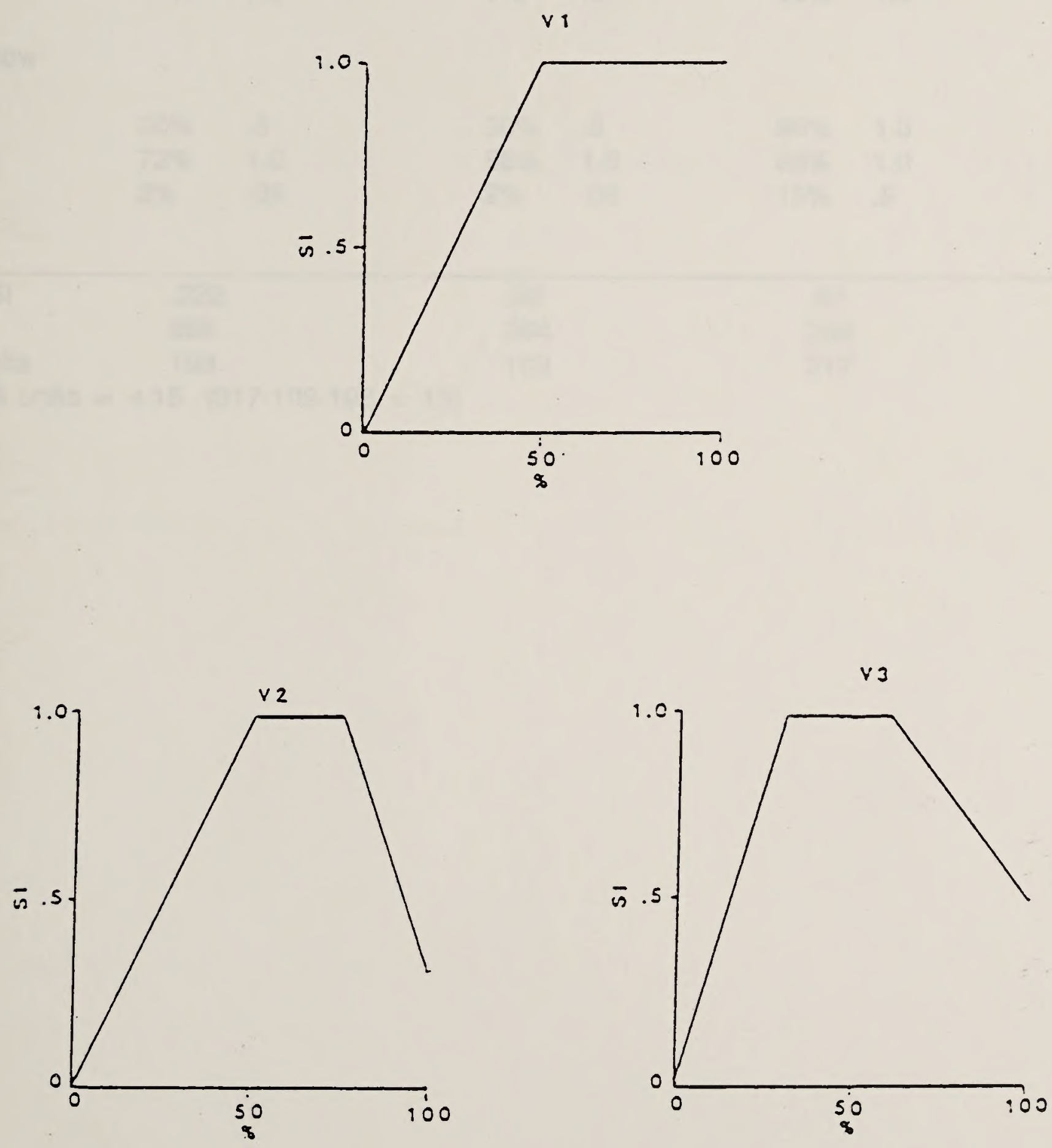

Table B-3. Parameter values and sultablity Indices for the elk model used for the Muddy Creek Reservoir project.

$\begin{array}{lllllll}\text { Variable } & \text { Project Area } & \begin{array}{l}\text { Mitigation area } \\ \text { Pre-management }\end{array} & \begin{array}{l}\text { Mitigation are } \\ \text { Post-manage }\end{array} \\ & \text { Value } & \underline{\text { SI }} & \text { Value SI } & \text { Value SI } \\ \text { Willow Riparian } & & & & & & \\ \text { V1 } & 30 \% & .8 & 30 \% & .8 & 90 \% & 1.0 \\ \text { V2 } & 59 \% & 1.0 & 53 \% & 1.0 & 53 \% & 1.0 \\ \text { V3 } & 24 \% & .85 & 7 \% & .2 & 30 \% & 1.0\end{array}$

Wet Meadow

$\begin{array}{lllllll}\text { V1 } & 30 \% & .8 & 30 \% & .8 & 90 \% & 1.0 \\ \text { V2 } & 72 \% & 1.0 & 88 \% & 1.0 & 88 \% & 1.0 \\ \text { V3 } & 2 \% & .05 & 2 \% & .05 & 15 \% & .5\end{array}$

\begin{tabular}{lccc}
\hline Overall HSI & .222 & .30 & .87 \\
Acres & 866 & 364 & 364 \\
Habitat units & 193 & 109 & 317 \\
Net habitat units $=+15(317-109-193=15)$ & &
\end{tabular}




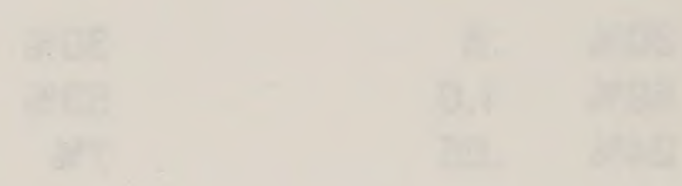

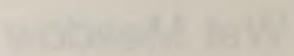


MODEL: General Wetlands Habitat Model

VARIABLE DESCRIPTION:

$$
\begin{aligned}
& V_{1}=\text { Percent herbaceous cover } \\
& V_{2}=\text { Percent of herbaceous cover that is graminoid } \\
& V_{3}=\text { Herbaceous Height }
\end{aligned}
$$

MODEL: $((2.5(\mathrm{~V} 1 \times \mathrm{V} 3))+.5(\mathrm{~V} 2)) / 3$

\section{SUITABILITY CURVES:}
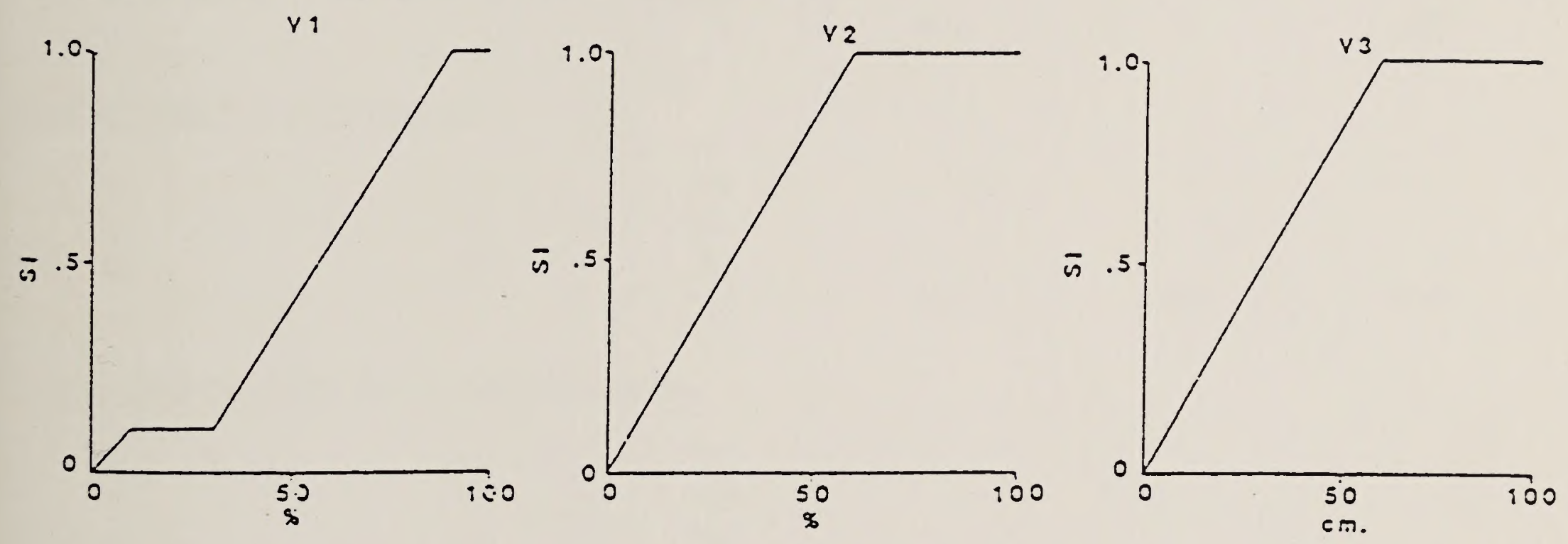

Table B-4. Parameter values and suitability indices for the general wetlands habitat modei used for the Muddy Creek Reservolr project.

\begin{tabular}{|c|c|c|c|c|}
\hline Variable & Projec & Area & $\begin{array}{l}\text { Mitigation area } \\
\text { Pre-management }\end{array}$ & $\begin{array}{l}\text { Mitigation area } \\
\text { Post-management }\end{array}$ \\
\hline & Value & $\underline{\text { SI }}$ & Value $\underline{\text { SI }}$ & Value $\underline{\text { SI }}$ \\
\hline$V_{1}$ & $45 \%$ & .33 & $45 \% \quad .33$ & 1.0 \\
\hline V2 & $72 \%$ & 1.0 & $88 \% \quad 1.0$ & $88 \% \quad 1.0$ \\
\hline V3 & $13 \mathrm{~cm}$ & .22 & $13 \mathrm{~cm} \quad .22$ & $60 \mathrm{~cm} \quad 1.0$ \\
\hline Overall HSI & \multicolumn{2}{|c|}{.225} & .225 & 1.0 \\
\hline Acres & \multirow{2}{*}{\multicolumn{2}{|c|}{$\begin{array}{l}825 \\
186\end{array}$}} & 210 & 210 \\
\hline Habitat units & \multirow{2}{*}{\multicolumn{2}{|c|}{$\begin{array}{l}186 \\
-23(210-47-186=-23)\end{array}$}} & \multirow[t]{2}{*}{47} & \multirow[t]{2}{*}{210} \\
\hline Net habitat $u$ & & & & \\
\hline
\end{tabular}




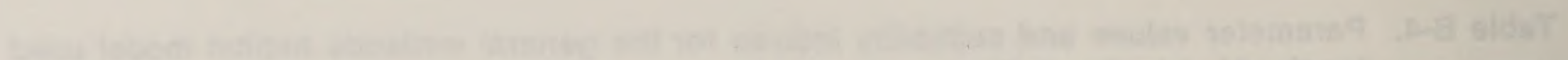

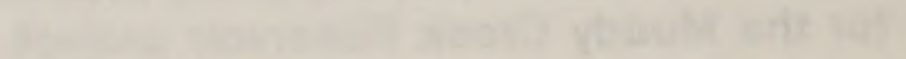

(1)

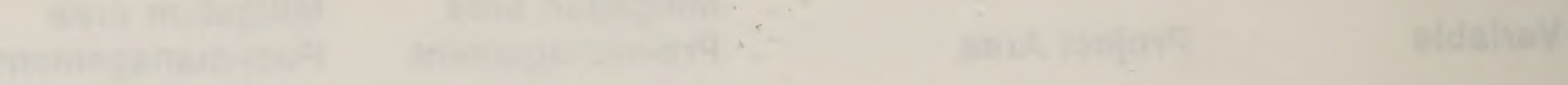

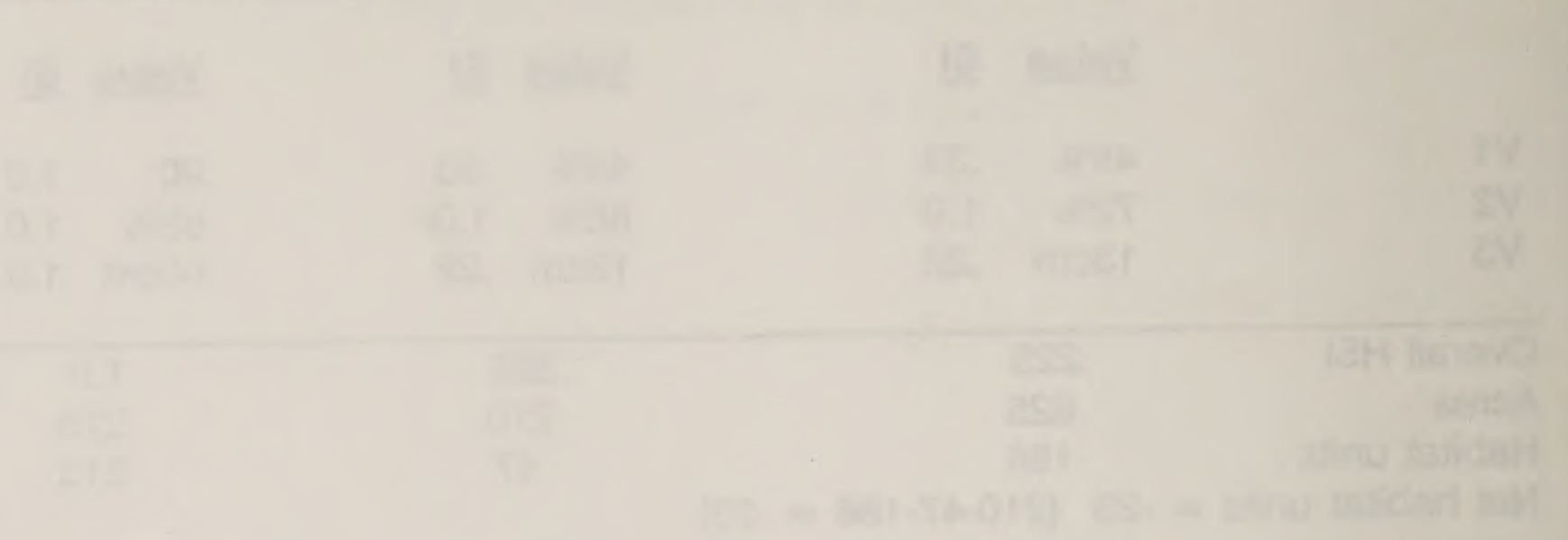


Table B-5. Summary of the results of the General Wetland Habitat (GWH) model for the wet subIrrigated meadow habitat on the proposed Muddy Creek project and mitigation areas.

WSM' In Good Condition Within Project Area

$\begin{array}{rrrrrr}\text { Variable }^{2} & \text { Value } & \frac{\mathrm{SI}^{3}}{82} & \underline{\text { Acres }} & \text { HSI }^{3} & \text { HU }^{3} \\ \mathrm{~V}_{1} & 76 & .82 & - & - & - \\ V_{2} & 72 & 1.0 & - & - & - \\ V_{3} & 27 & .45 & - & .47 & 67 \\ - & - & - & 143 & .47\end{array}$

WSM In Poor Condition Within Project Area

$\begin{array}{lrr}V_{1} & 30 & .1 \\ V_{2} & 72 & 1.0 \\ V_{3} & 5 & .08\end{array}$

Overall WSM Within Project Area

$\begin{array}{lll}V_{1} & 45 & .33 \\ V_{2} & 72 & 1.0 \\ V_{3} & 13 & .22\end{array}$

Overall Existing WSM Within Mitigation Area

$\begin{array}{lll}V_{1} & 45 & .33 \\ V_{2} & 72 & 1.0 \\ V_{3} & 13 & .22\end{array}$

\section{Overall Post-Management WSM In Mitigation Area}

$\begin{array}{lrr}V_{1} & (90-100) & 1.0 \\ V_{2} & >60 & 1.0 \\ V_{3} & >60 & 1.0 \\ - & - & -\end{array}$

1.0

1.0

Shortfall of HUs on Lower Muddy Creek Mitigation Area $=23$

${ }^{1}$ WSM $=$ Wet sub-irrigated meadow

$2 V_{1}=\%$ herbaceous canopy cover, $V_{2}=\%$ herbaceous canopy cover that is graminoid, $V_{3}=$ average herbaceous height $(\mathrm{cm})$

${ }^{3} \mathrm{SI}=$ Suitability index for variable as determined by model $\mathrm{HSI}=$ Habitat suitability index $=\left(\left(2.5\left(\mathrm{~V}_{1} \times \mathrm{V}_{3}\right)\right)+.5\left(\mathrm{~V}_{2}\right)\right) / 3$

$\mathrm{HUs}=$ Habitat units where HSI $\times$ Acres $=\mathrm{HU}$ 

Table B-6. Summary of changes to elk model assoclated with wetland impacts for the Muddy Creek Mitigation Plan.

\section{Project Area \\ Existing \\ Mitigation Area}

Acres HSI HUS

Acres HSI HUS

Acres HSI HUS

$831 \quad .39 \quad 324$

$\begin{array}{lll}515 & .15 \quad 77\end{array}$

$515 \quad .8$

399

Draft

Mitigation 695

$.04 \quad 28$

$345 \quad .18 \quad 62$

$345 \quad .39$

135

Plan $^{2}$

Final

Mitigation 866

$.222 \quad 193$

$364 \quad .30 \quad 109$

364

.87

317

1. $\mathrm{HSI}$ values are based on the following model:

$$
\frac{\left(\mathrm{Fl}_{a}+\mathrm{VCl}_{\Omega}+\mathrm{TCl}_{\Omega}\right)}{3}=\mathrm{HSI} \text { for vegetation type a }
$$

where: $\mathrm{FI}($ Food Index $)=\frac{\underline{V}_{1}+V_{2}+V_{3}}{3}$

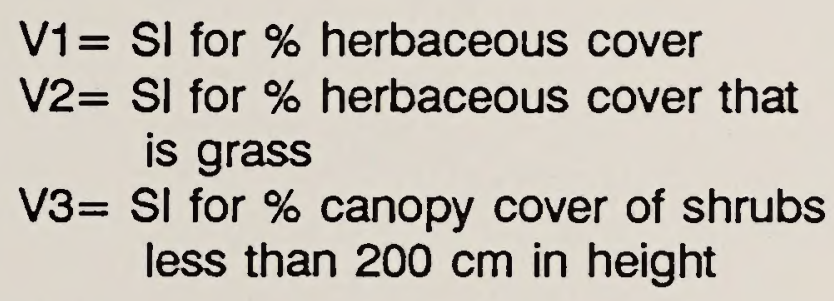

$$
\begin{array}{ll}
\mathrm{VCl} \text { (Negetative }=\left(\mathrm{V}_{5} \times \mathrm{V}_{6}\right)^{1 / 2} & \mathrm{~V} 5=\text { Horizontal hiding cover } \\
\text { cover index) } & \mathrm{V} 6=\text { Cover type height } \\
\mathrm{TCl}\left(\text { Topographic }=\left(\mathrm{V}_{7} \times \mathrm{V}_{8}\right) / 2\right. & \mathrm{V} 7=\text { Topographic diversity } \\
\text { cover index) } & \mathrm{V} 8=\text { Aspect index }
\end{array}
$$

Total elk HSI for study area= summation of the products of the HSI for a vegetation type times the \% of the total area occupied by that type.

- Vegetation types included wet subirrigated meadow, willow riparian and sagebrush.

2. $\mathrm{HSI}$ values are based on the following model:

$$
\begin{aligned}
& \left.\left(V_{10} \times V_{2 a}\right)_{2}^{1 /} \times V_{3 a}\right)^{1 / 2}=\mathrm{HSI} \text { for vegetation type a } \\
& \qquad \begin{aligned}
V 1 & =\mathrm{SI} \text { for } \% \text { herbaceous cover } \\
\mathrm{V} 2 & =\mathrm{SI} \text { for } \% \text { herbaceous cover that } \\
& \text { is grass } \\
V 3 & =\mathrm{SI} \text { for } \% \text { canopy cover of shrubs less than } 200 \mathrm{~cm} \text { in height }
\end{aligned}
\end{aligned}
$$




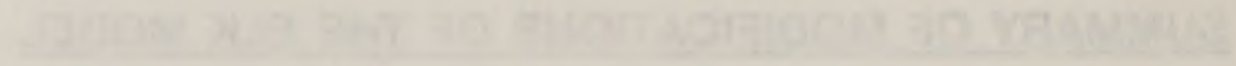

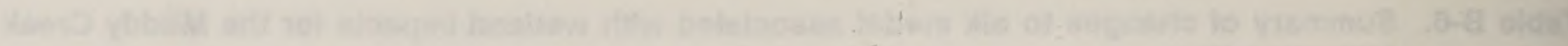

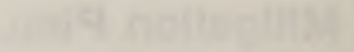

and

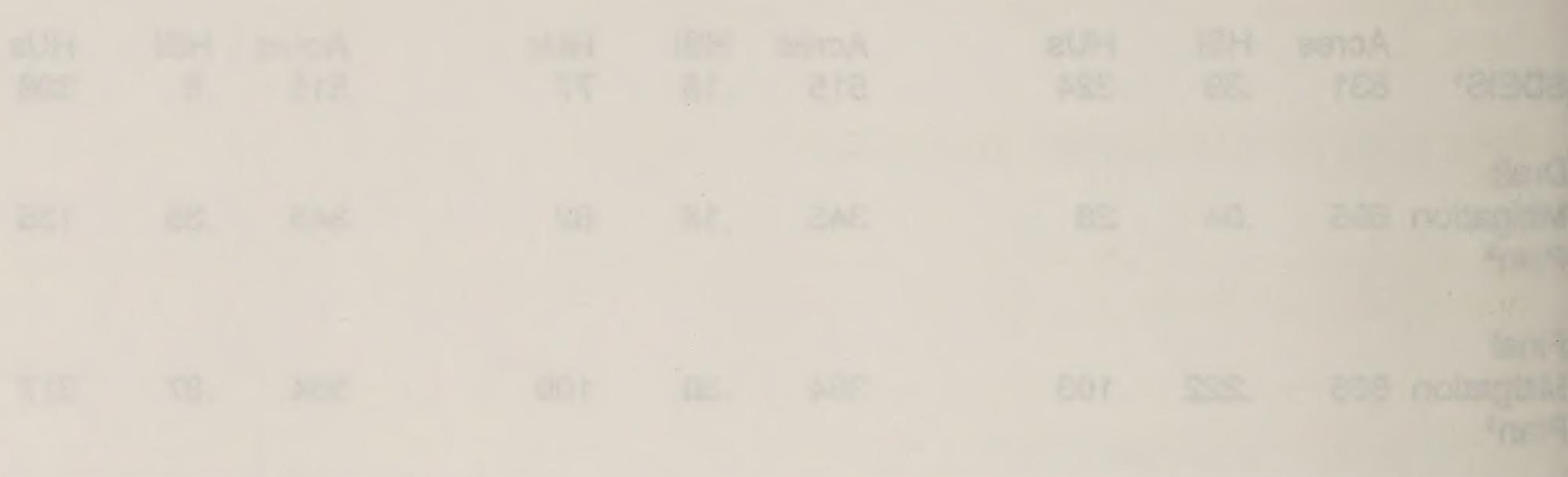

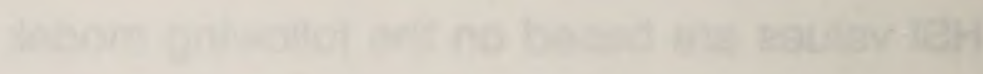

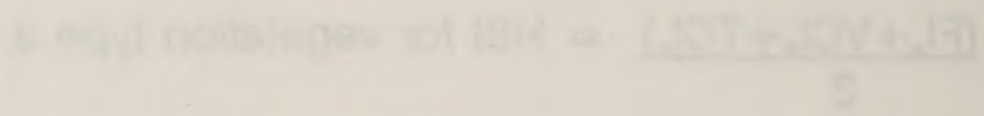

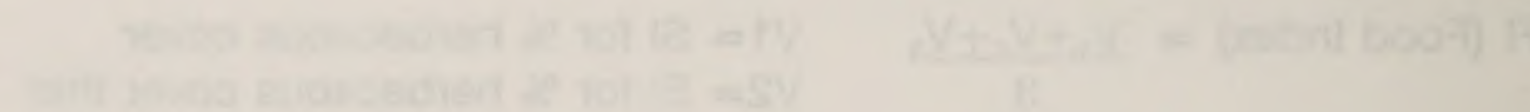

4.

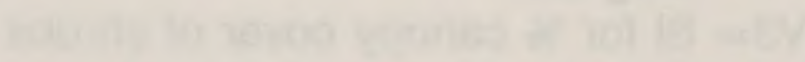

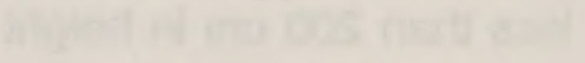

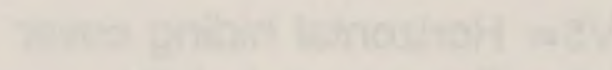

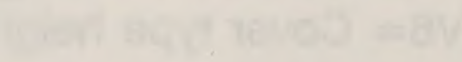

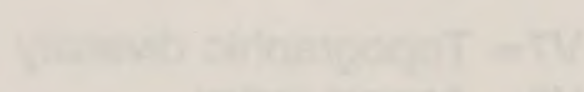

ans

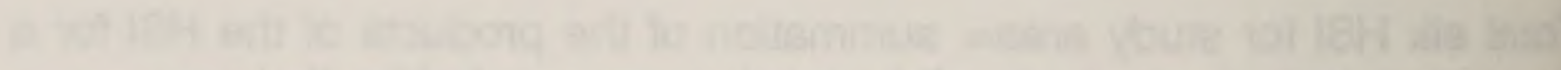

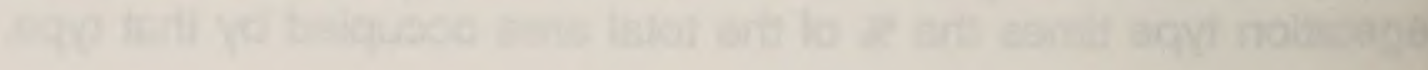

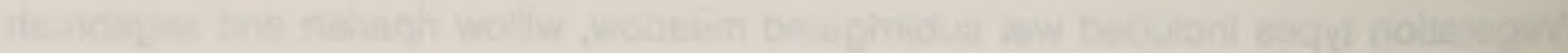

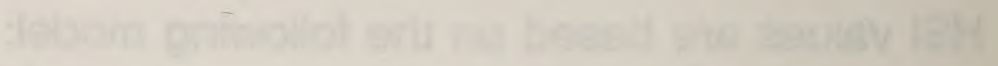

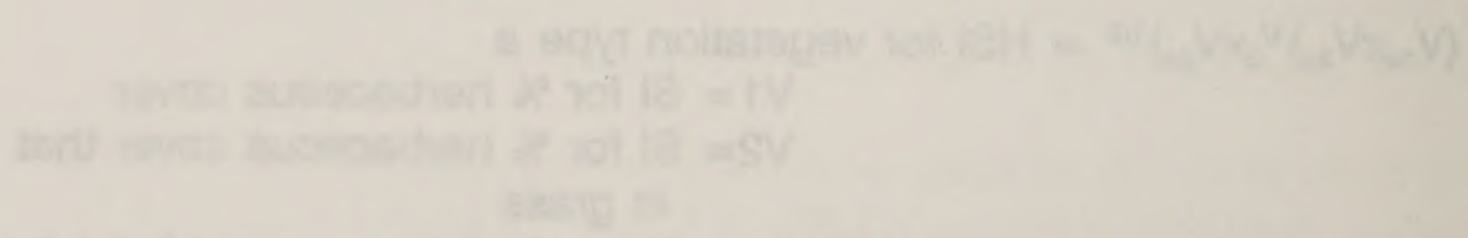




\section{Table B-6. Continued}

2. (cont.) Total elk HSI for study area= summation of the products of the HSI for a vegetation type times the percent of the total area occupied by that type.

- Vegetation types included wet subirrigated meadow and willow riparian.

- Acreage for project area does not include man created wet meadows and acreage in the mitigation area is based on more detailed mapping of mitigation area than for the SDEIS.

3. HSI values are based on the same model as presented in \#2. Modifications include:

- Inclusion of the cottonwood riparian type acreage with the willow riparian type acreage in the mitigation area.

- Acreage in the project area includes naturally wet subirrigated meadow, man created wet meadow, willow riparian and cottonwood riparian.

- The assumption that a small amount of willow cover (1 percent) exists in the wet meadow vegetation types that was not picked up by vegetation sampling methods. 
(3)

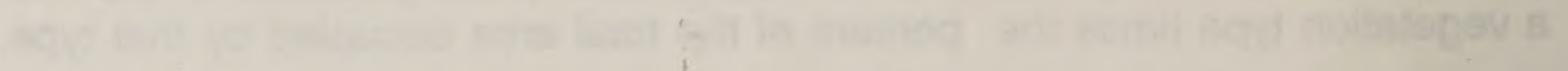

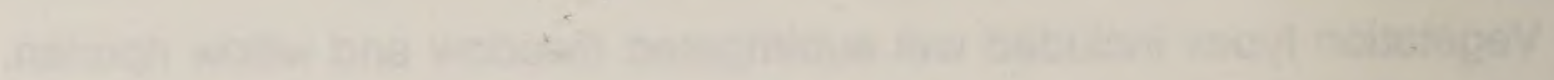
-

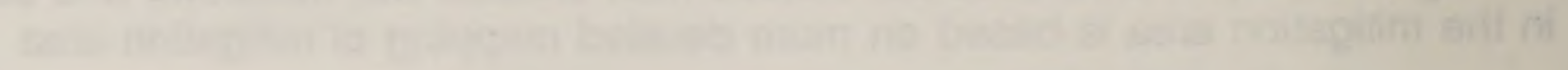

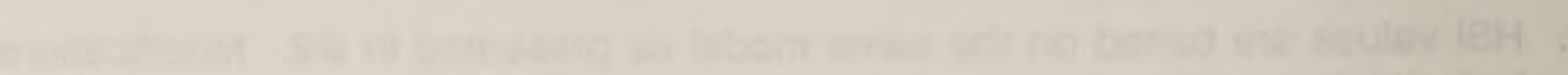

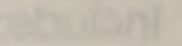


MAPS \# 1, 2, 3

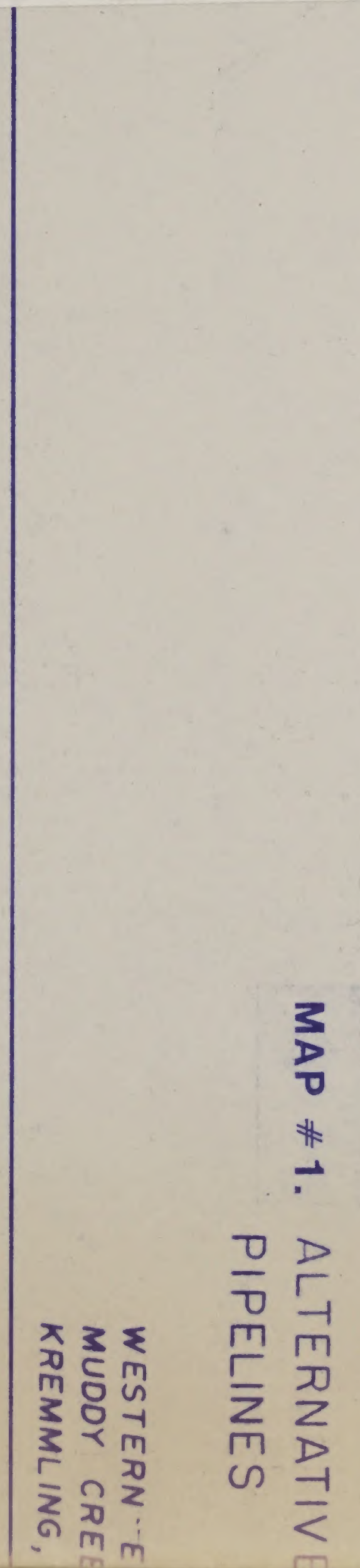






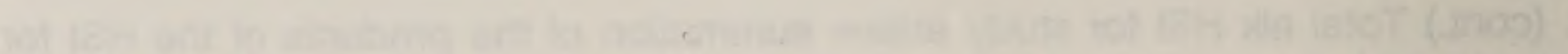

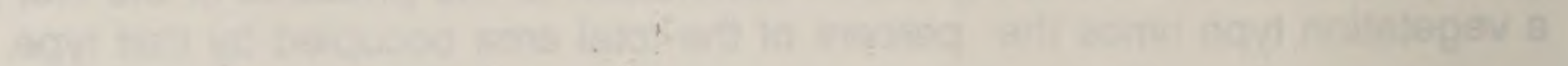

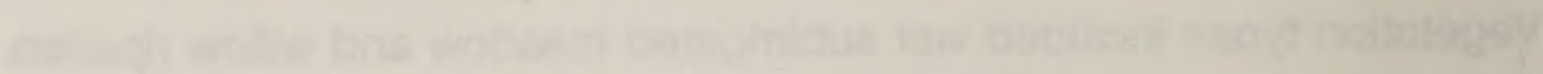
-

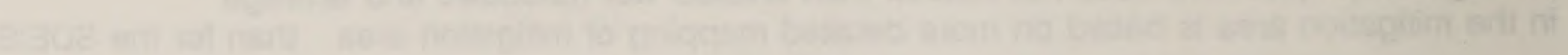

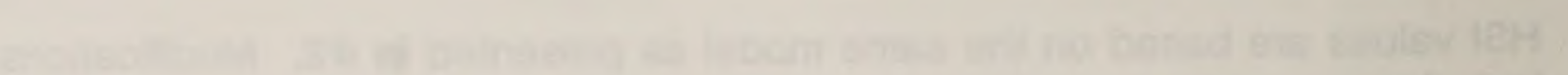
3ath nani

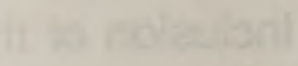
casis

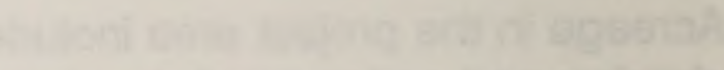

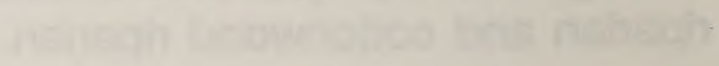

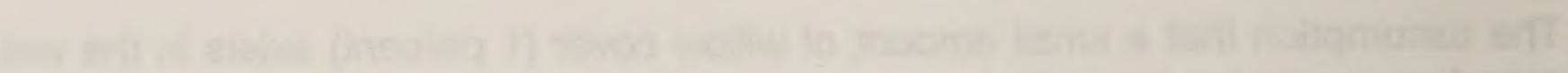

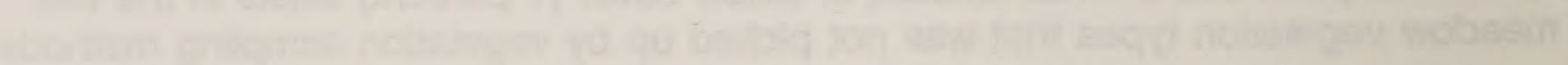



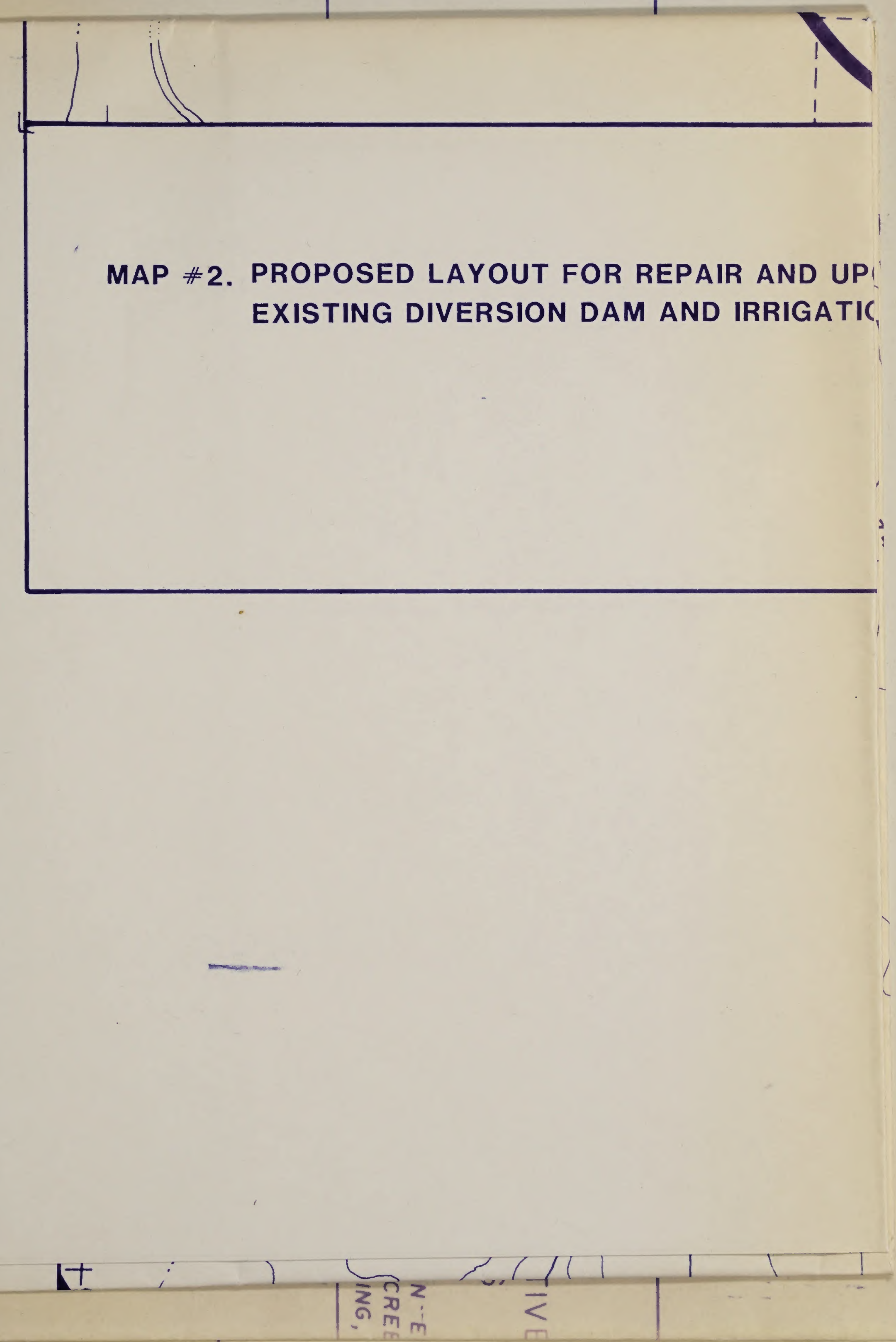



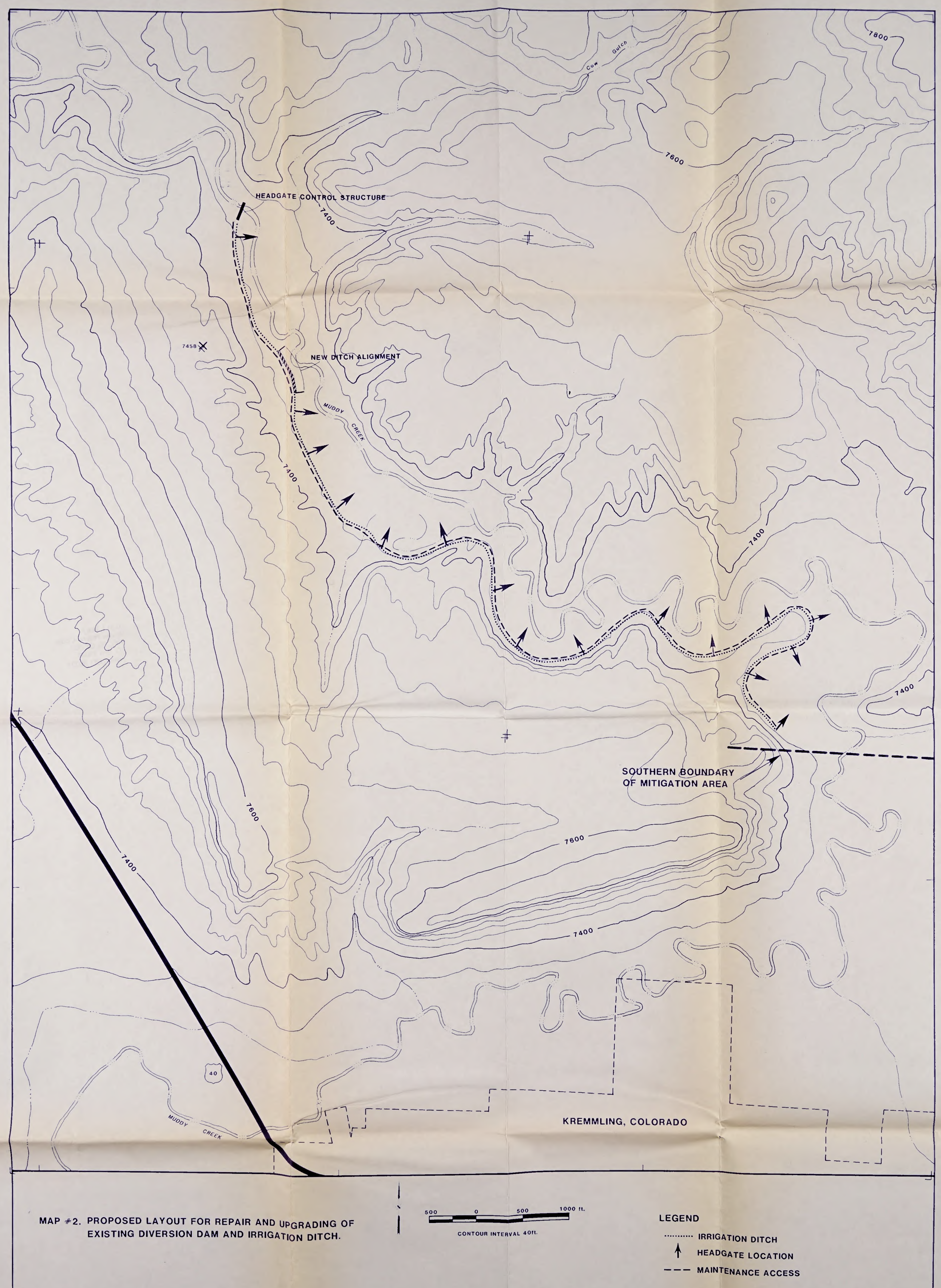




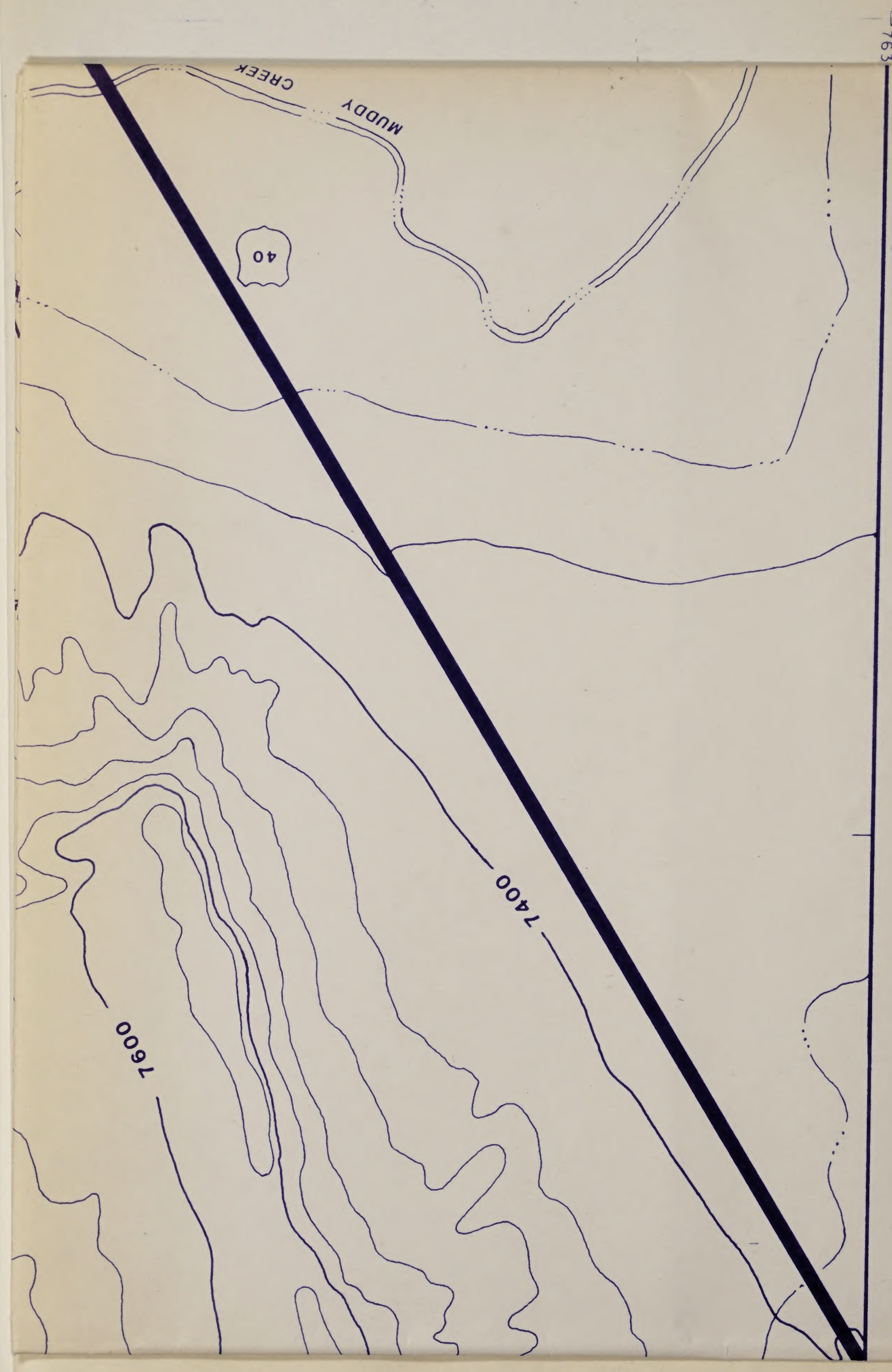





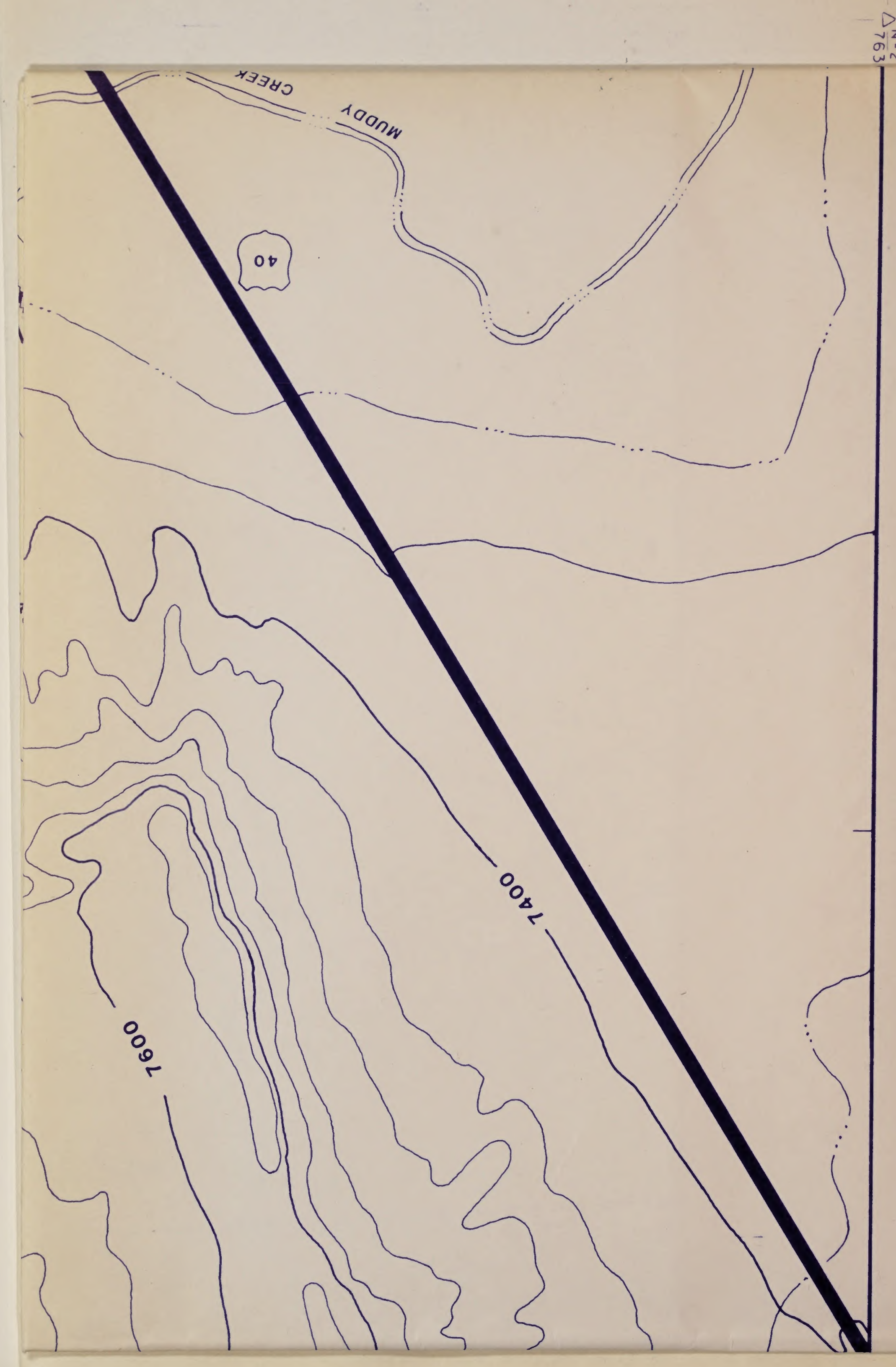





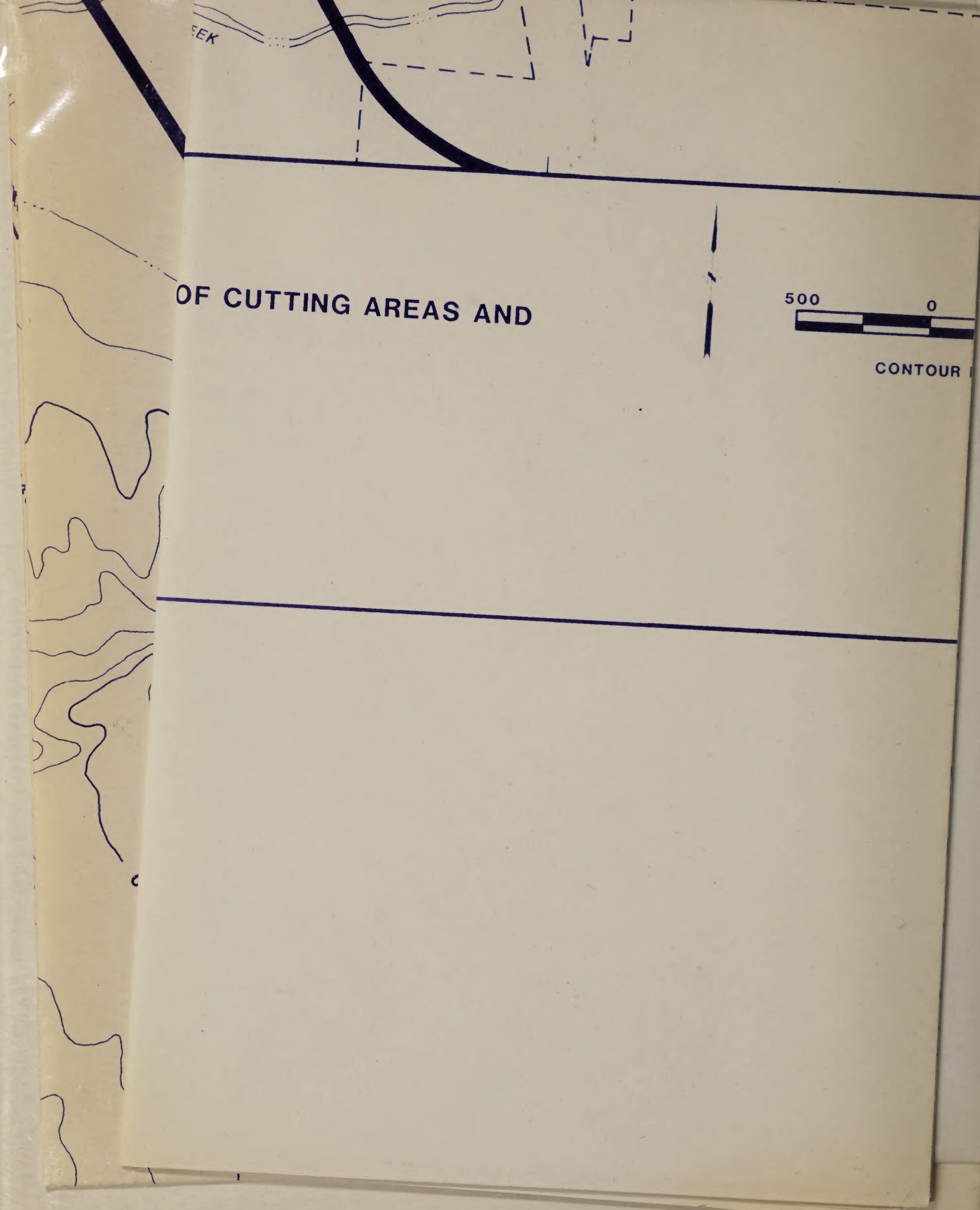




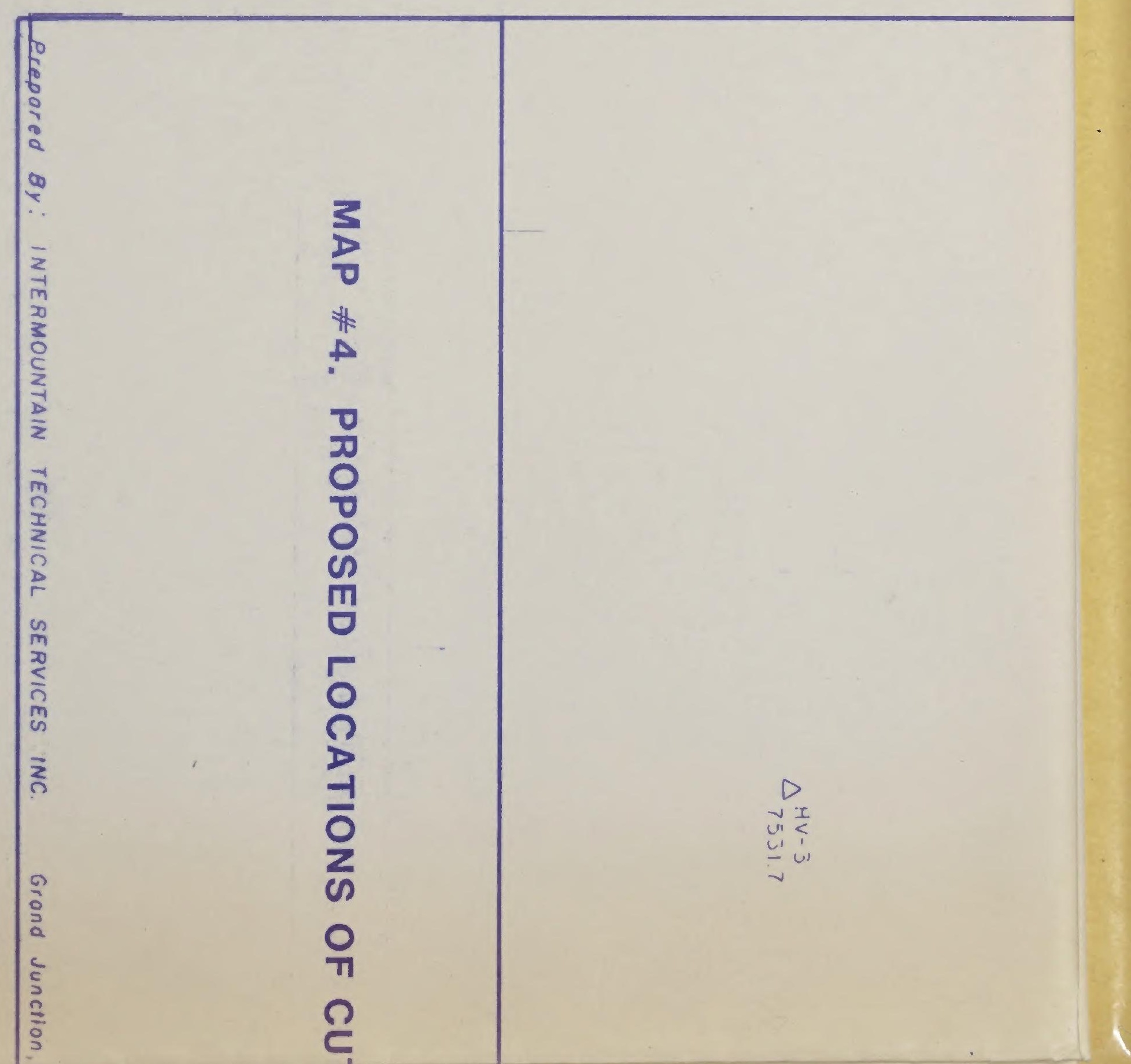




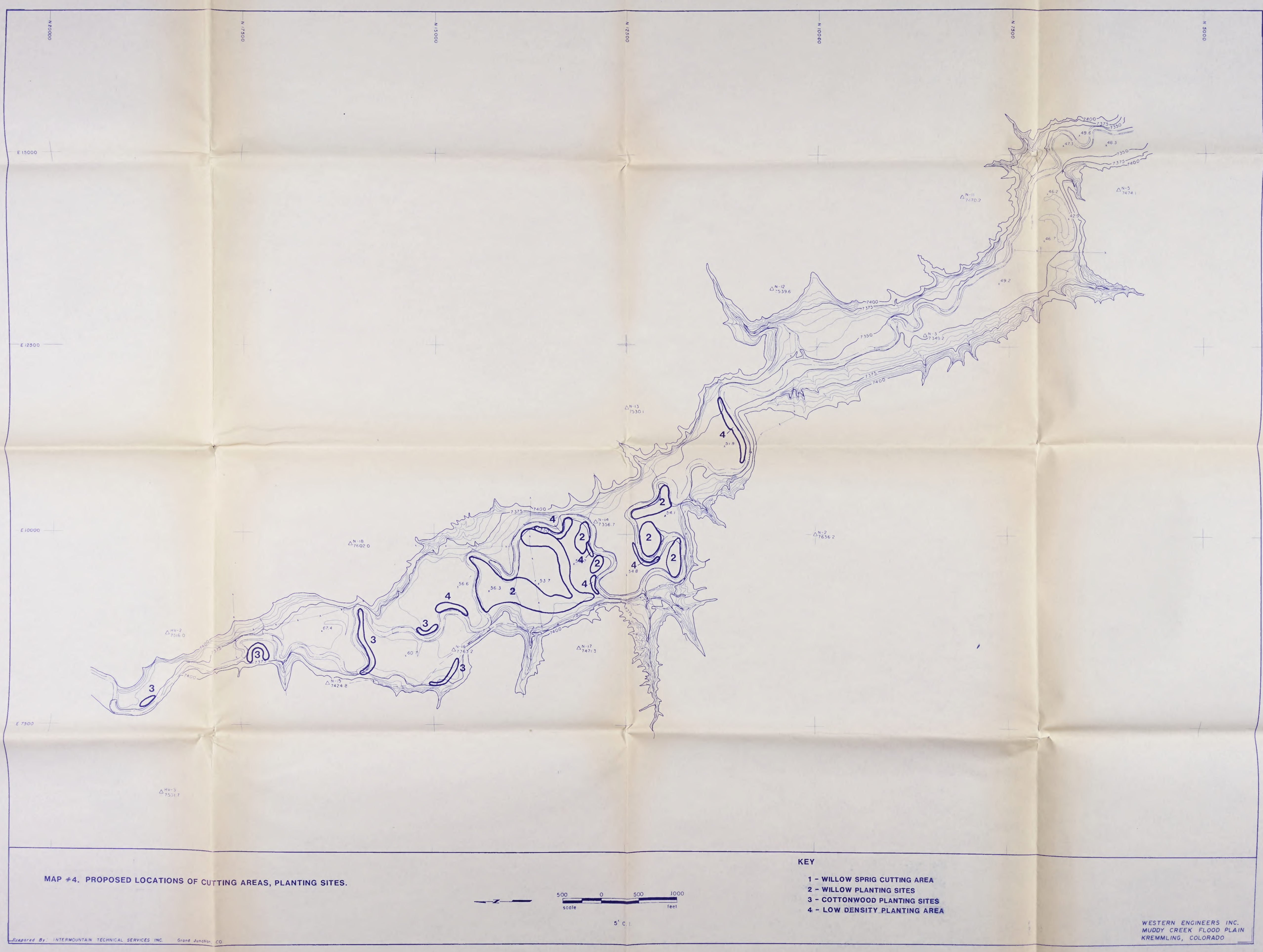


ฐั

$m$
$\overline{0}$
0
0

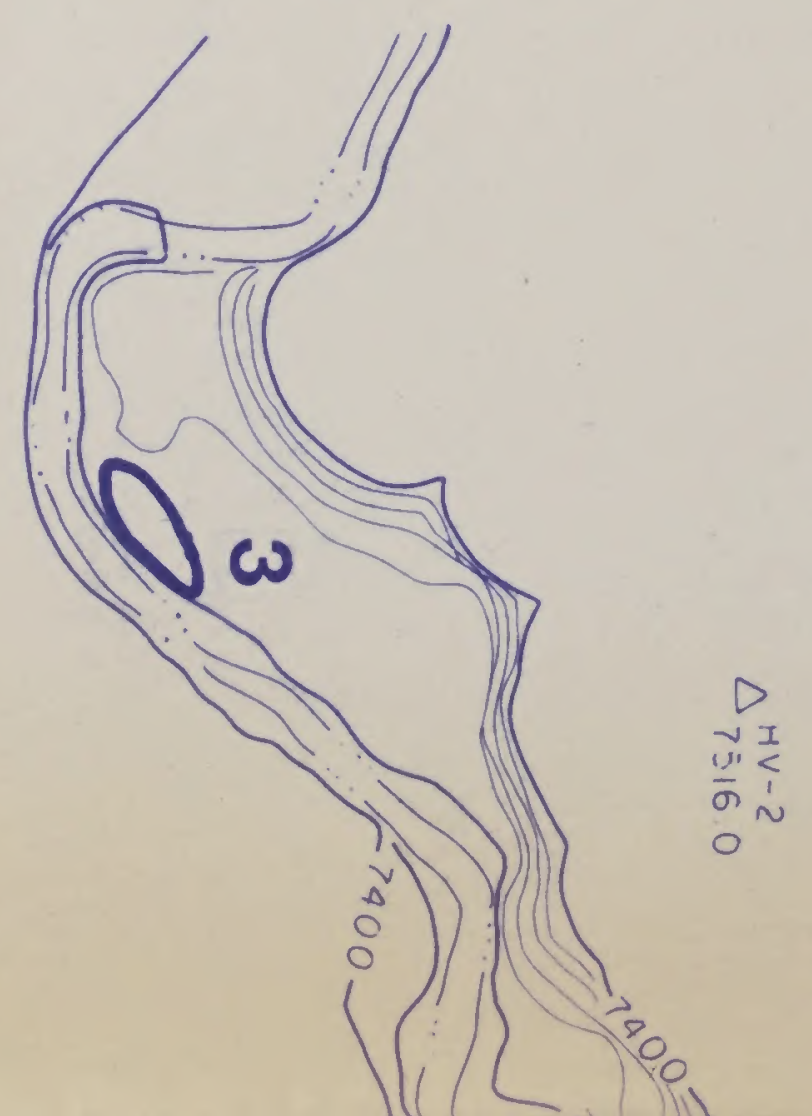




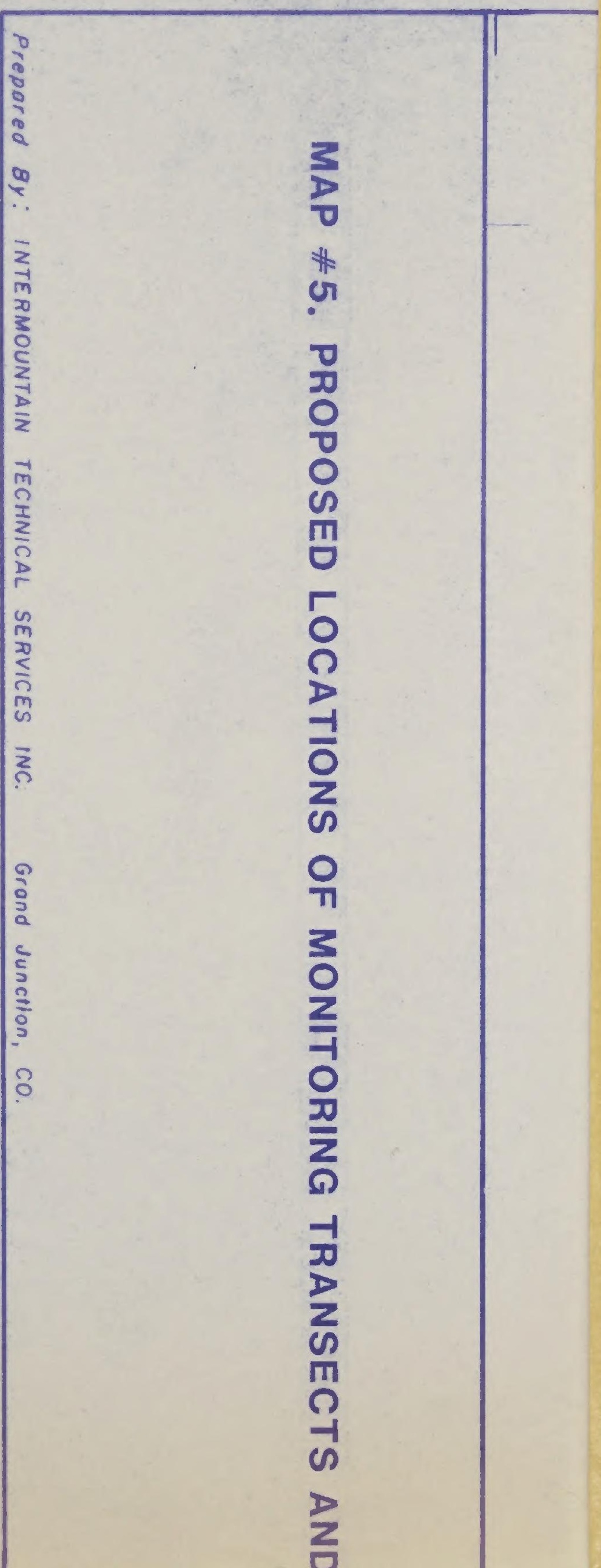


<smiles>C/C=C\CC=CCCC</smiles> 


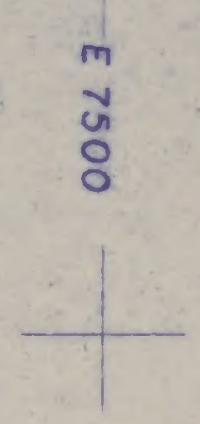

品

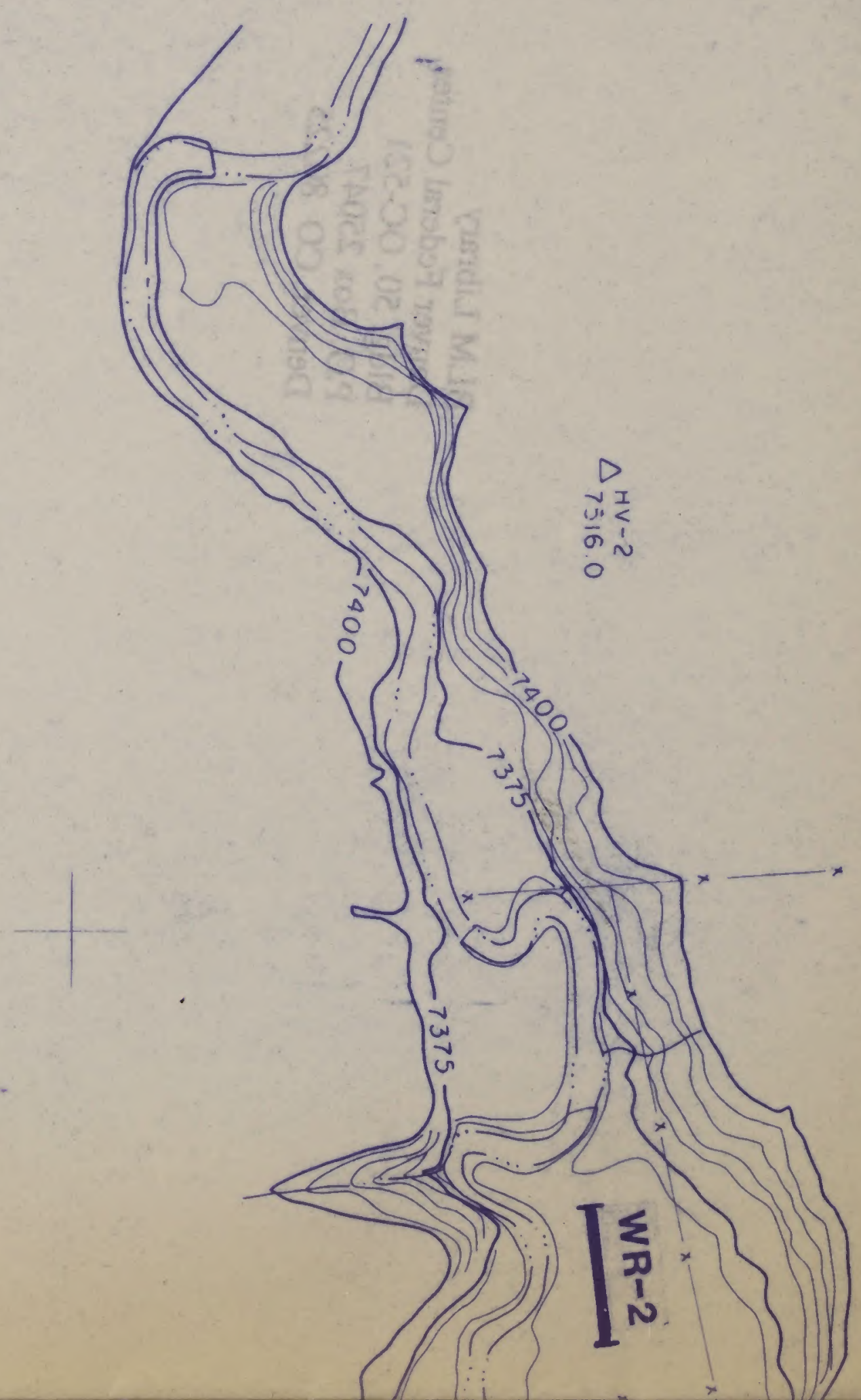





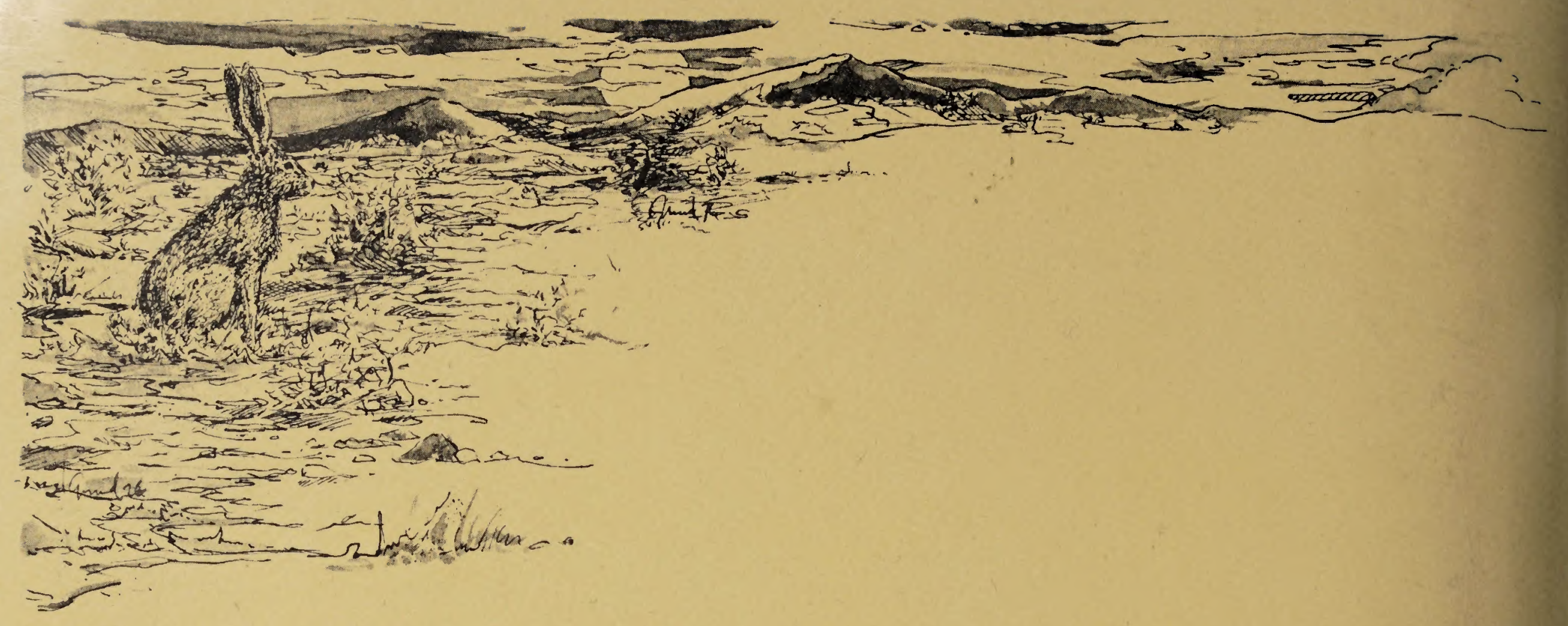

\section{$\mathrm{BIO} / \mathrm{WEST}$, Inc.}

1063 West 1400 North

P.O. Box 3226

Logan, Utah 84321

(801) $752-4202$

Art

by

Scott Greenwood

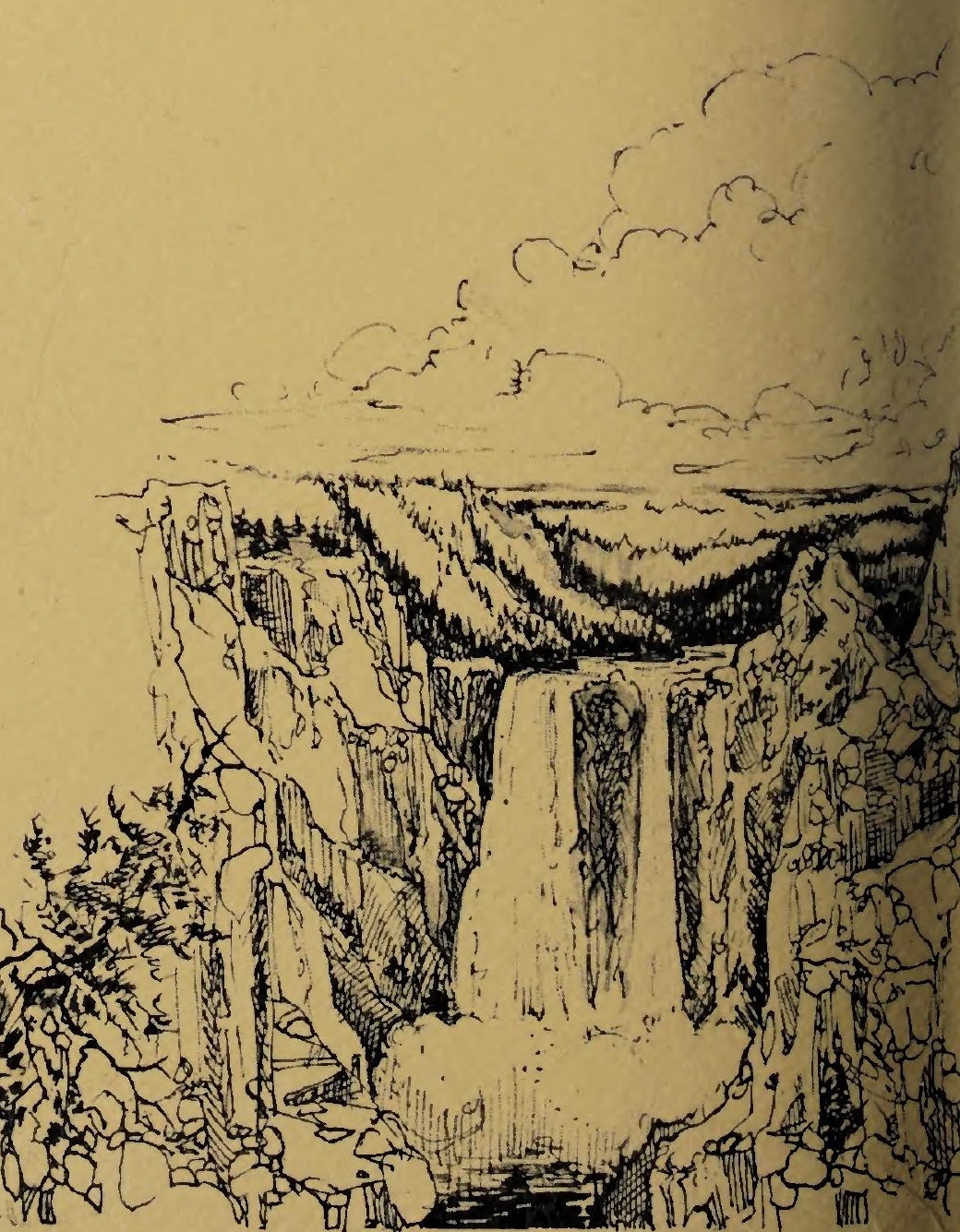

